Historic, archived document

Do not assume content reflects current scientific knowledge, policies, or practices. 



\section{PERFECTION BRAND SEEDS}

\section{The Binding-Stevens Seed Co.}

$\therefore$ TULSA, OKLAHOMA

D. N. Shoemaker

HAR 3 YG⿻一𠃋

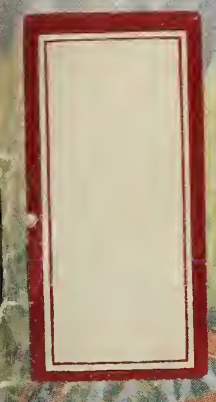

Were

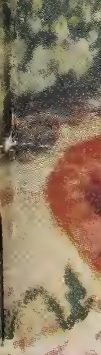

1 .

Cat
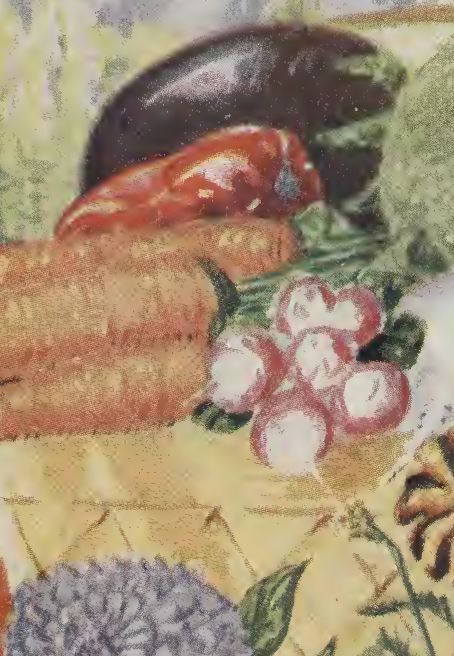

Q.

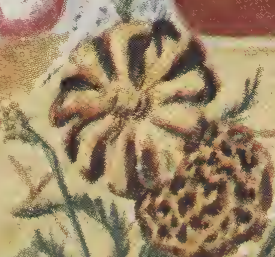




\section{FOREWORD}

The year 1924 brought to us the largest business we have ever handled in the same number of months; and the gratifying thing, to us, is that this increase was largely due to our old customers buying in larger quantities. We assure you that we will adhere to the principle, on which this business has been built, that no seeds shall leave our store that have not been grown under the most favorable conditions that we know of, and that are not as clean as the best of machinery and trained men can make them, and then each lot must show its ability to grow; this is proven in our testing laboratory before the seeds are labeled PERFECTION BRAND SEEDS. It will save you money to order Beans, Peas, Sweet Corn, and Cucumber early. These crops turned out a very small yield, and some varieties are very short indeed. It will be necessary to advance prices on some vegetable seeds in quantities larger than one fourth pound and, therefore, we quote quantity prices subject to market changes. We wish one and all a prosperous year in 1925 .

\section{The Binding-Stevens Seed Company}

Since 1905

TULSA, OKLAHOMA

\section{LARGER CROPS in FIELD and GARDEN}

Registered in the

United Statos Dec. 6th, 1898.

\section{YEARS AGO.}

\section{if you use}

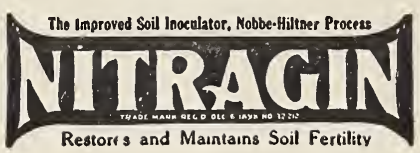

\section{Awarded Gold Medal}

Worlds Fair - St. Louis

1904.

Alfalfa, clovers, soybeans, vetches, peas, beans, cowpeas, pea nuts and other legumes should always be inoculated witn

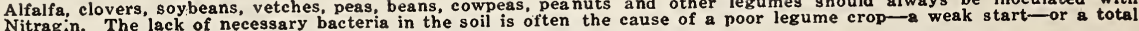
Nitrag.
failure.

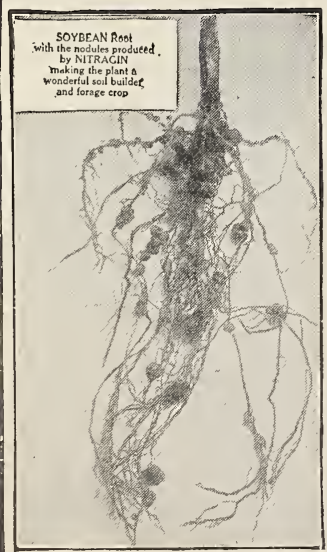

\section{A Great Price Reduction NITRAGIN Costs Less} Nitragin now comes in Bushel sizes instead of acre sizes. This means that it costa
you less per acre than inferior imitations. If you sow 12 pounds of seed to the acre it will only cost you 20 cents for your Nitragin. It means that

\section{Your Dollar Goes Further With NITRAGIN}

Nitragin is an old, reliable inoculator. At the low price of 20 to 33 cents per acre you cannot afford to sow legumes without it. Nitragin is put up in the modern ventilated package; in a rich, soil-like packing medium. The contents are always fresh, living bacteria to feed your plants. Easy to use.

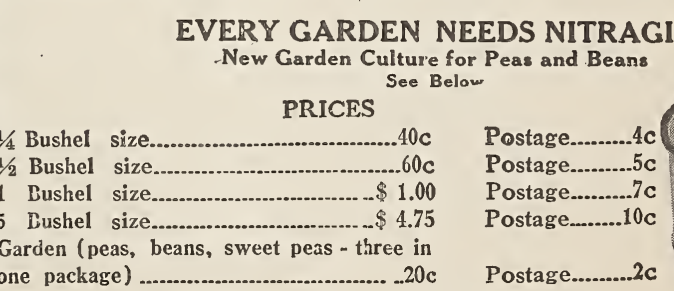


IN ORDERING PLEASE USE THIS SHEET; ALSO RETURN ENVEI,OPE ENCLOSED. We will be glad to furnish more of each when wanted. The Binding-Stevens Seed Co. TULSA, OKLA.

Terms are Cash With Order. No Goods Sent C. O.D.

Name

Post Office.

R F. D. No.

County.

State.

\section{Please Do Not Write In This Space}

Shipped by

Packed by.

We give no warranty, express or implied, as to description, quality, productiveness or any other matter of any seeds, bulbs or plants we send out and we will not be in any way responsible for the crop.

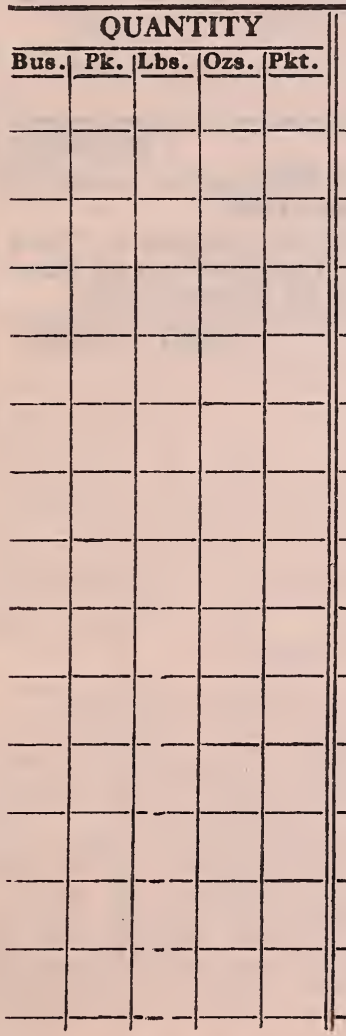

\begin{tabular}{|l||l|l|l}
\hline NAMES OF SEEDS WANTED & PRICE \\
\hline & & & \\
\hline & & & \\
\hline & & & \\
\hline
\end{tabular}

NAMES OF SEEDS WANTED

Amount Enclosed.

P.O.Order. $\$$

Express Order .....\$.

Draft. $\$$.

Cash ...

Regis'd Letter......\$.

\section{Postg. Stamps......\$ 2c Stamps Preferred Total $\$$...}

Date 1925. 


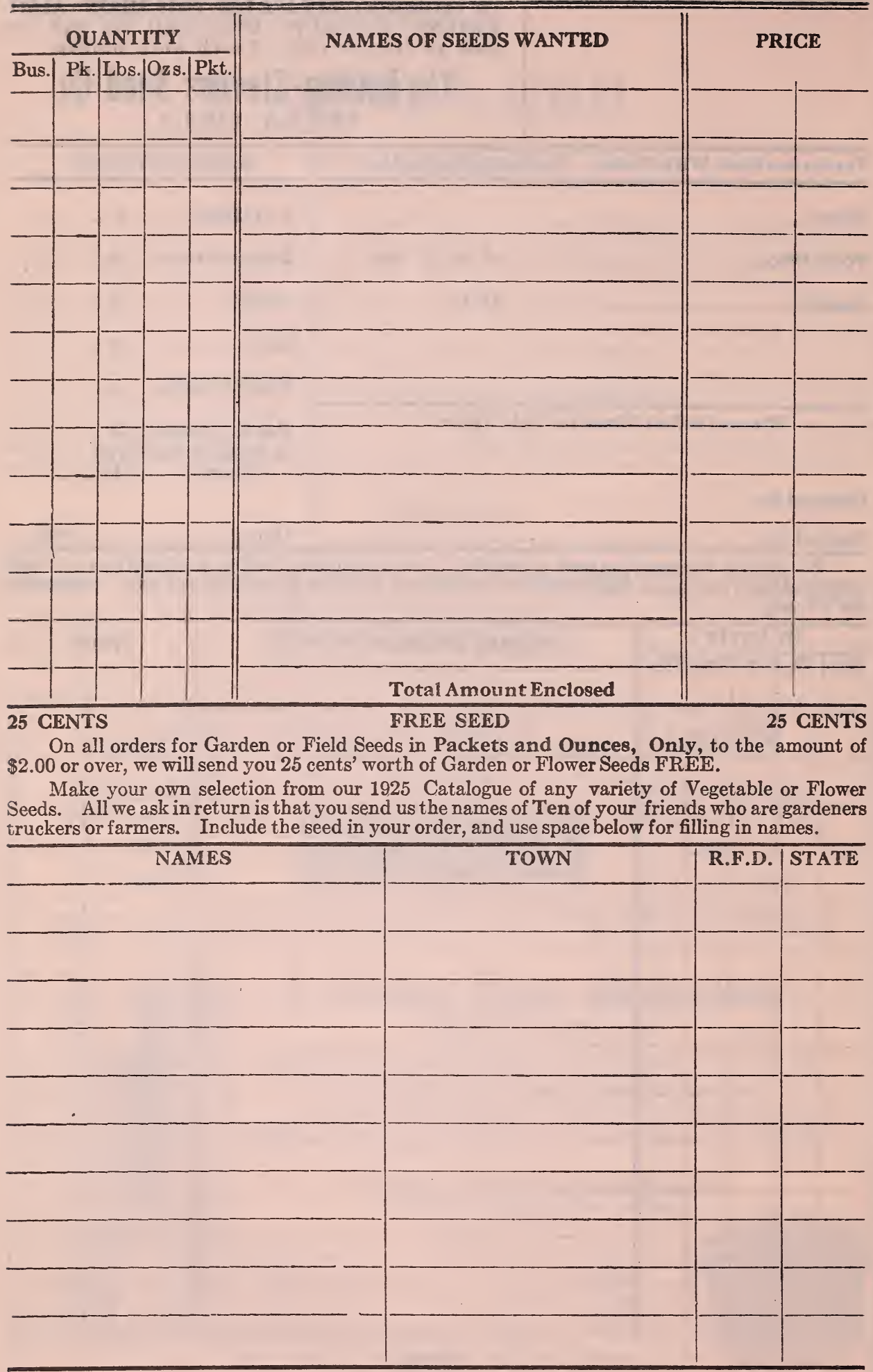




\section{Suggestions In Ordering}

A reading of the following will prove an aid to you and to us:

Our Prices-Including bags, boxes, and free cartage to the depot.

The prices quoted in this catalog include free delivery on packets, ounces, $1 / 4$ pounds, pounds (except where otherwise stated). "By freight or express" means that transportation charges are paid by the customer.

Early Orders-Our rush season comes in the months of March and April. Orders sent at once secure prompt shipment from our full stock.

How to Order-Write your name, postoffice, State, and express office plainly with black ink on every order and every time you write us. Give plain express, mail, of freight directions. Where none are given, we route at buyer's risk.

Market Gardeners and others who buy vegetable seed in bulk to the amount of $\$ 10.00$ or more are requested to send their list of seeds wanted to us and let us make special quotations.

Plant Orders-Orders for plants will be filled as early in the spring as we consider it safe to send them. If ordered for immediate shipment in severe weather, they will be sent at purchaser's risk.

Use Order Sheets-The use of order sheets enclosed in this Catalog is a great help to us in facilitating filling and shipment of orders. More will be sent on receipt of postal asking for same.

About Warranting Seeds-It is impractical to guarantee seeds, as the best seeds will fail under improper treatment. Soma may be sown in too dry ground or too wet, too deep, or too shallow. Some hardy seeds will stand cold weather and will grow where the soil is too cold for others and would cause them to decay. Insects may attack and destroy them. For these reasons we do not give warranty in any respect, and will not be responsible for the crop.

\section{Your Vegetable Garden}

\section{Planning}

Do not plant a larger garden than you can take care of. It is better to work a small spot intensively than to fail with a big one. Draw a plan for the garden and decide what is to go in it and exactly where it is to go. Get your seeds, tools, and fertilizers on hand before the spring opens up.

\section{Soil}

The garden is always intensive farming consequently the soil must be rich. A good application of stable or barn-yard manure is of excellent value, in lieu of this a good high grade commercial fertilizer should be applied.

Plow or spade the ground in the fall or early spring. Harrow or rake it until the earth is fine and all the clods are removed.

\section{Succession Planting}

Do not think that one crop a year is all that the garden will yield. With a proper planning two or three crops can be raised from most of the gardens.

\section{Our Services Are at Your Disposal}

This means that if you find a new "bug" on the Cabbage, an unknown pest on the Potato, or if you have doubts how to can Tomatoes, let us help you. We are more than glad to do all that we can to make your garden a success. We want to make every garden planted with PERFECTION Seeds a bright spot in its locality. We will supply Seeds that will do it and are ready to help you all that we can in the subsequent, necessary care of the garden.

We wish you all possible success. 


\section{Garden Seeds}

Asparagus................. 5

Beans........................5-8

Beets.......................... 9

Borecole.........................15

Brussels Sprouts..............10

Cantaloupe.................17-18

Celery...........................10

Carrot..........................10

Cabbage......................11-12

Frost Proof Plants ..........68

Corn-Sweet....................13

Corn Salad.....................14

Collards................................12

Cauliflower.................14

Cress..........................14

Cucumber...................15

Dill...........................14

Egg Plant........................... 14

Endive............................14

Garlic........................14

Gumbo..............................

Garden Collections, 3d Cvr.

Kale...........................15

Kohl-Rabi.....................16

Leek.............................16

Lettuce......................16-17

Medicinal Herbs...............32

Muskmelon.....................17

Mustard.........................21

Okra..........................21

Onion...................22-23

Onion Sets......................23

Oyster Plant.....................28

Parsnip........................23

Parsley.........................23

Peas..........................24

Pot Herbs .....................32

Pepper..........................25

Pie Plant.......................27

Pumpkin..................25-26

Potatoes.....................29

Radish.................26-27

Rhubarb....................27

Salsify ..........................28

Spinach .....................28

Squash........................28

Sweet Herbs.................32

Turnip......................... 33

Tomato......................30-31-32

Tobacco..........................32

Vegetable Plants..............33

Watermelon.................19-20

\section{Farm Seeds}

Alfalfa

50-51

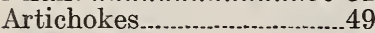

Broom Corn...................55

Buckwheat...................46

Corn .............................45

Cotton Seed..................46

Cow Peas......................48

Clover................. 49-50-51

Cane...............................55

Feterita....................54

Grass Seeds..............52-53

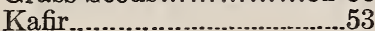

Mangel Wurzel................56

Millet.
Milo Maize....................54

Nitragin ......1st. Cover........

Oats.........................46

Pop Corn........................46

Peanuts.......................49

Rye..........................46

Rape........................47

Soy Beans.....................47

Speckled Velvet Bean .....47

Sunflower.....................49

Sudan Grass...................53

Sugar Beets ....................56

Vetch...........................47

Velvet Beans..................47

\section{Flower Seeds}

Amaranthus..................34

Alyssum................................

Ageratum........................34

Aster..........................34

Balsam..........................34

Balsam Apple....................41

Bachelors Button.................35

Carnation......................35

Cypress Vine.....................41

Columbine......................35

Cannas........................43

Calliopsis.........................35

Candytuft..........................35

Celosia...........................35

Cosmos........................35

Chrysanthemum................35

Dahlia.........................36

Elephants Ear...............43

Foxglove....................36

Four o'clock....................36

For-get-me-not................36

Gaillardia....................36

Geranium......................36

Gypsophila.....................34

Hollyhock..................37

Hibiscus.......................37

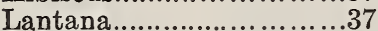

Larkspur...................37

Lupin..........................37

Marigold.....................37

Mignonette........................37

Moonflower...................42

Morning Glory................42

Marvel of Peru................36

Nasturtium......................38

Pansy...........................38

Petunia......................38

Poppy...........................39

Phlox.......................39

Ornamental Gourds .......42

Portulaca.......................39

Ricinus........................39

Scabiosa ......................40

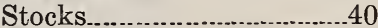

Salpiglossis.....................40

Shasta Daisy...................36

Sweet William................40

Salvia.............................40

Sweet Peas...................42

Snapdragon....................40

Scarlet Runner...................42

Thunbergia....................41

Vine Seeds..................41-42

Verbena........................41
Vinca .......................41

Wistaria.......................41

Zinnia.......................41

Bedding Plants

Bulbs.......................43

Insecticides-Fungicides Disinfectants

Slug Shot......................44

Grape Dust....................44

Hofstra.......................44

Sure Noxem ................44

Tobacco Dust................44

Lime Sulphur Solution.....44

Cutworm Food .............44

Black Leaf 40 ...............44

Paris Green...................44

Arsenate of Lead.. ............44

Bordeaux Mixture ...........44

Nitragin......1st. Cover ......

\section{General Supplies}

Canary Birds.................57

Bird Cages....................57

Seed Cups..........................57

Bird Cage Springs...........57

Bird Baths....................57

Bird Seed......................57

Cuttle Fish Bone................57

Bird Manna.................57

Bee Supplies...................60

Paper Bands and Pots........68

Ratnip.............................63

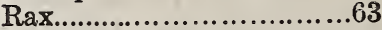

Dog Biscuits ..........................57

Poultry Foods

Scratch Food..................61

Chick Food ..................61

Laying Mash ..................61

Ground Beef Scraps .........61

Buttermilk Starting Food 61

Ground Bone...................61

Oyster Shell ..................61

Charcoal.......................61

\section{Poultry Supplies}

Leg Bands.

Toe Punch

Egg Testers.

Nest Eggs...

Grit and Shell Box...........62

Drinking Founts..........62-64

Feeders......................62-64

Avian Bacterin...................67

Don Sung...................62

Avicol..........................65

Caponizing Sets.............67

Egg Boxes.....................63

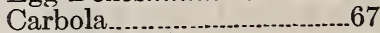

Incubators....................66

Brooder Heater...........63-65

Putnam Stove.

Carbolineum.

\section{Garden Tools}

Hand Cultivators .............59

Weeders ..........................59

Spray Pumps................58-59

Garden Plows...................60

Hudson Seeder......................60

Seed Sowers........................58 


\section{Market Gardeners, Truck-Growers Large Farmers, Attention}

We urge that you go over the Catalog carefully, make up a list of seeds you need and send to us for prices.

Our years of experience in the seed business have put us in close touch with the grower, and understanding the soil and climate of this section puts us in a much better position to serve you than any outside concern.

We carry a complete line of selected and tested seeds, and can supply your wants, quality considered, at as reasonable prices as any other seed house.

We are here to serve you, and hope you will not hesitate to call upon us.

\section{TESTED GARDEN SEEDS ASPARAGUS}

Asparagus is one of the first vegetables in spring, as well as one of the best grown in the garden. It is perfectly hardy, grows year after year from the same roots and never fails to produce a crop. Asparagus does well on any well-drained soil, but the best results are obtained from rich, deep, loamy soil.

Barr's Mammoth-The large, green stalks of this variety are tender and delicious, and are ready considerably before the common sorts. The delicacy of its color distinguishes it from the other green varieties.

Columbian Mammoth White-The b e s t white sort.

Palmetto-A very early maturing and prolific variety, producing an abundance of very large, deep green shoots of the best quality.

Prices on any of the above. Pkt. 10c, oz. 15c, $1 / 4$ 1b. 40.

\section{ASPARAGUS ROOTS}

For those who desire to raise asparagus, one of the earliest of the spring vegetables, we suggest the purchase of asparagus roots. These are ready during March, but to be sure of getting them you should reserve your stock now by sending us your order.

Our strong two-year-old roots will give the best results in the shortest time possible.

Columbian Mammoth White-Two-year-old roots. Per dozen, 40c., postpaid; by express, $\$ 1.75$ per 100.
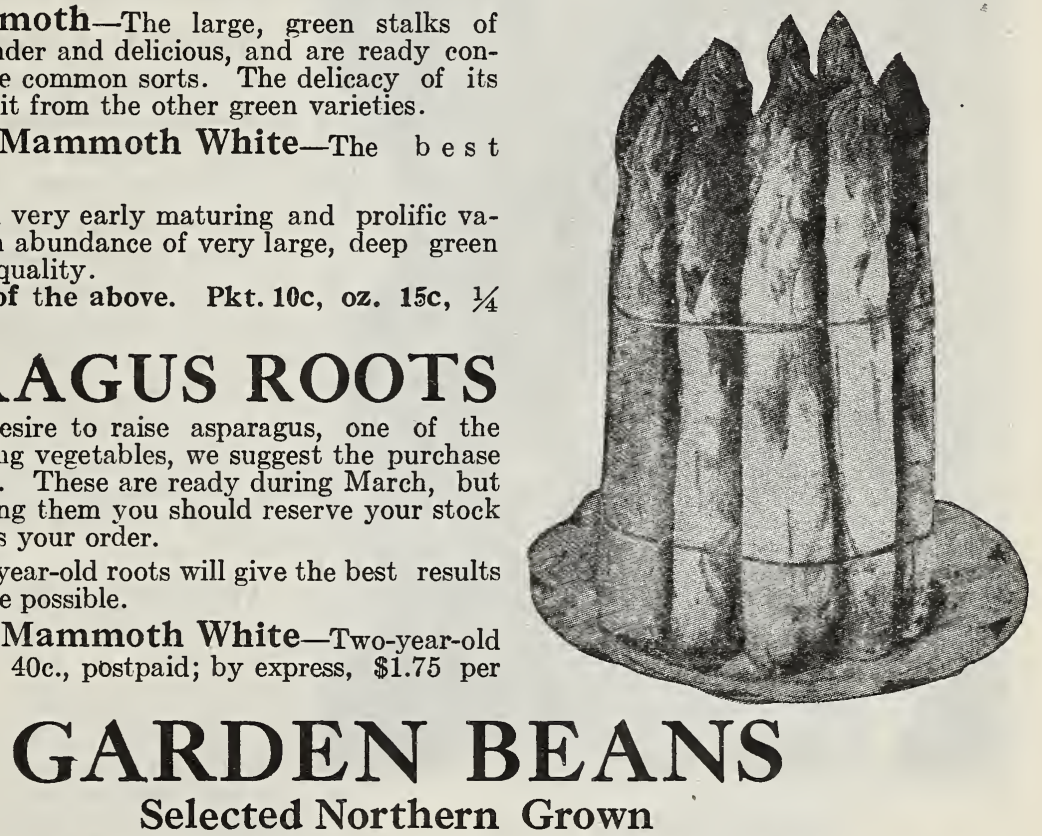

When all danger of spring frost is over is the time to plant beans, as they thrive little, if any, when the soil, days and nights are cold. Given moisture, this crop can be planted in the South in succession until the middle of August. A good, sandy loam is the best soil for beans, but they will grow well in any soil of average richness.

The bush varieties should be planted $1 \frac{1}{2}$ inches deep in drills 18 inches or 2 feet apart, 2 inches apart in the drill. When the plants are well up, thin gradually to 6 or 8 inches from each other leaving the strongest plants as much as possible. The pole variety should be planted two or three beans in a hill, 2 feet apart each way. Give them clean cultivation, mellowing the soil about them, but not going too deep, hilling broad and flat about the time they are to bear. Do not hoe them when wet from dew or rain, as this induces rust of leaves or pods.

A pound will plant 100 feet of drill; 2 bushels, or $120 \mathrm{lbs}$. to the acre in drills.

For a larger yield of Beans, use Nitragin. (See Inside Front Cover.) 


\section{GARDEN BEANS-Continued}

Tennessee Green Pod- This dwarf, early, intermediate snap bean is very popular in some sections of the South, and wherever known in other parts of the country is spoken of in terms of highest praise. The vines are large, somewhat spreading, and prolific. The foliage a dark green, with leaves large and crumpled. The pods are very long - very often 6 to 7 inches, -flat, irregular in shape, bright, but rather dark green, and of excellent quality; seed of medium size, oval, flat, yellowish brown in color. Pkt., 10c; lb., 40c; postpaid. By express, lb., 35; 10 lbs., $\$ 3.00$.

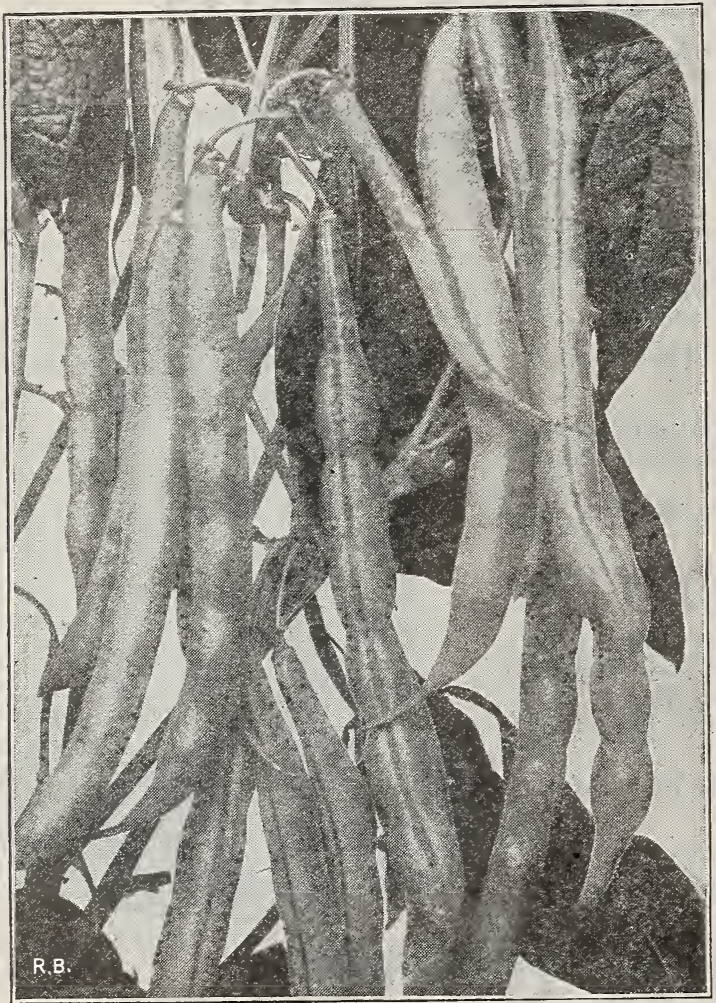

Stringless Green Pod Beans

Burpees Stringless Green PodSplendid for market and home garden. Is one of the most popular beans in America. In earliness it is in the lead, in quality it is unexcelled, and as a cropper it is unrivaled. It is stringless in reality as well as name. It is an abundant cropper and the pods are thick, round, fleshy and nearly straight. Ready for picking in 45 days. Lb., 40c, postpaid. By freight or express, lb. $35 \mathrm{c}, 10 \mathrm{lbs}$., $\$ 2.75$.
Refugee (1000 to 1) - Exceedingly heavy cropper, highly esteemed for late planting. Pods long cylindrical, light green, of good quality as snaps, mild in flavor with slight strings. Ready to pick in 55 days. Lb., 35c, postpaid. By freight or express, $1 \mathrm{~b} .30 \mathrm{c}, 10 \mathrm{lbs}$., $\$ 2.00$.

\section{Giant Stringless Green Pod} - This is a great improvement on the old-time popular favorite Valentine Bean. The pods are fully one-third longer, averaging 5 and 6 inches in length; absolutely stringless, very crisp, round, full and fleshy. It is enormously productive, its handsome pods being ready for market a few days earlier than the old Valentine. We confidently recommend it, either for the home garden or as a profitable variety to grow for market. Pkt., 10c; lb., 40c, postpaid. By freight or express, lb. 35c, $10 \mathrm{lbs}, \$ 2.75$.

\section{Round Pod Red Valentine-}

The full meaty pods are a rich color, unsurpassed in tenderness. The plants are healthy, vigorous and unusually hardy, withstanding slight frosts, which invariably kill other varieties. It permits, therefore, an early planting. It develops quickly producing handsome, long fleshy pods of extra fine quality. We recommend this variety highly to market gardeners although it is as desirable for the home garden. A thorough trial will convince our customers of the excellence of this new sort. Pkg., 10c; lb., 40c, postpaid. By freight or express, lb .35c, 10 lbs. $\$ 2.50$.

White Navy Beans-Planted in June or July, these usually make a profitable crop to grow as shelled white beans for the market. Plant in rows 3 feet apart, dropping two or three beans together 1 foot apart in the rows. Cultivate early, as they grow rapidly, but do not work them while the dew is on the foliage, and care should be used not to cultivate them deeply after 2 or 3 inches high. Do not cultivate after they begin to blossom. Carefully grown, these will prove a very profitable and successful crop. It requires about 15 pounds to the acre. Pkg., 10c; lb., 25c; postpaid. By freight or express, 10 lbs., $\$ 1,60$.

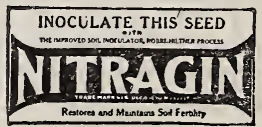




\section{GARDEN BEANS-Continued}

PENGIL POD BLACK WAX - A bushy, heavy yielding, medium early sort, bearing round, clear, rich yellow pods from 5 to 6 inches long; entirely stringless, very meaty and tender; seed black. Ready to pick in about 50 days. Pkt., 10c; lb., 35c, postpaid. By freight or express, lb. 30c, 10 lbs., $\$ 2.50$.

WARDWELL'S KIDNEY WAX-Very prolific early sort, with long, flat, brittle pods of golden yellow color. Pkt., 10c; lb., 40c, postpaid. By freight or express, lb., 35c; 10 lbs., $\$ 3.00$.

IMPROVED GOLDEN (RUSTPROOF)Very valuable rustproof strain of the Golden Wax which stands drouth remarkably well; pods rather flat, nearly straight, fleshy, and of highest quality. Pkt., 10c; lb., 40c, postpaid. By freight or express, lb., 35c; 10 lbs., $\$ 2.75$.

GURRIE'S RUSTPROOF WAX-Is the earliest to mature of either the green or wax beans. It is ready for the market in forty-five days from date of planting. Its beautiful pure golden, long, flat pods of extra fine quality are borne in abundance and attract the admiration of both planter and the consumer. Being the first in the market, it always commands most profitable prices. Entirely free from rust and blight. Pkt, 10c; lb., 35c, postpaid. By express or freight, per lb. $30 \mathrm{c}$; 10 lbs., $\$ 2.50$.

\section{Pole or Running Beans}

KENTUCKY WONDER WAX-This remarkable vigorous-growing, wax-podded pole bean is very similar to the green-podded Kentucky Wonder, but the very long pods are a little broader, very fleshy, and quite stringless as snaps. The pods are attractive light yellow and when mature are often 8 or 9 inches in length. Seed medium size, oval flattened, very irregular, dark brown. Its earliness and hardiness commend it as a pole bean, well adapted for northern latitudes. Pkt., $10 \mathrm{c}$; lb., $45 \mathrm{c}$, postpaid. By freight or express, per lb. $35 \mathrm{c} ; 10$ lb. $\$ 3.00$.

LAZY WIFE-Prolific sort, with handsome entirely stringless pods. They measure from $41 / 2$ to 6 inches in length, are thick and fleshy, and retain their rich, tender, and luscious quality until neary ripe. The white, dry seeds make excellent winter shelled beans, and extend the season considerably. Pkt., 10c; lb., 40c, postpaid. By freight or express, 35c per lb.

CUT SHORT OR CORNFIELD-Green beans; resembling those of the Bush Valentine dry beans, red-speckled. Pkt., 10c; lb., 35c, postpaid. By freight or express, 30c per lb.

DUTCH CASEKNIFE-One of the earliest of the pole varieties; white seeds; used for snaps; good green or dry; a good winter sort, productive, and a good bean for planting among corn. Pkt., 10c; lb., 35c, postpaid.

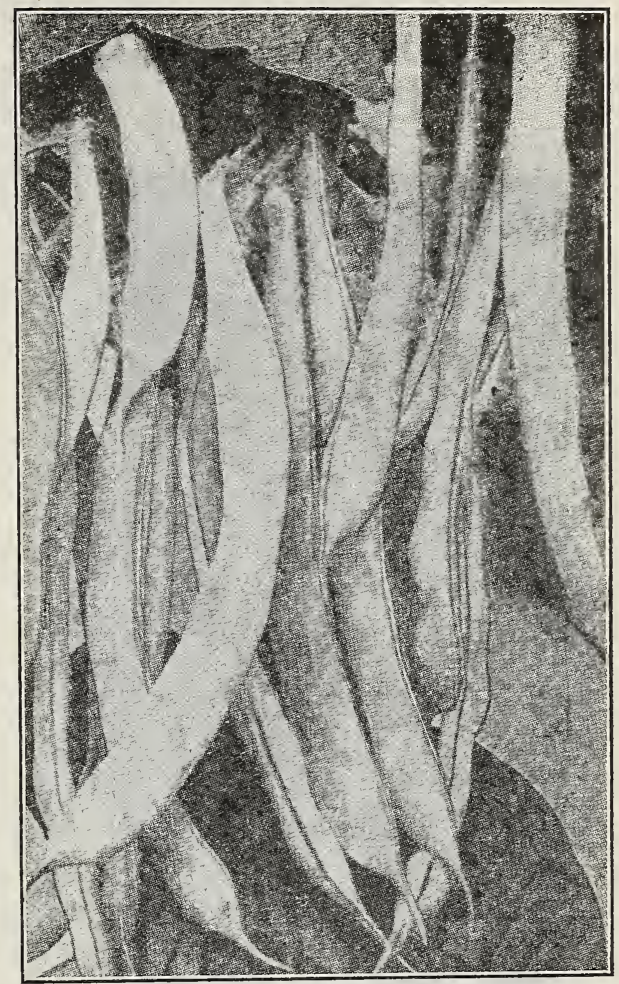

Improved Rust Proof Golden Wax Bean

OCTOBER OR HORTICULTURAL-A popular and productive variety for use as snaps or as shell beans. It is especially adapted for mountainous districts or where the season is short. Per lb., 35c, postpaid. By freight or express, $30 \mathrm{c}$ per $\mathrm{lb}$.

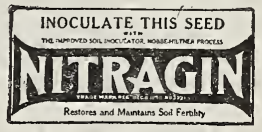

20c. Plus 2c Postage.

Inoculates from one oz. package up to eight pounds of seed. ( 3 IN ONE) Bacteria Fertilizer for PEAS, SWEET PEAS and BEANS. Insures a better quality, larger crops and faster growth. Nitragin germs feed the plant nitrogen, taking it from the air in the soil. This helps to make the plants strong and vigorous. 


\section{GARDEN BEANS--Continued}

\section{Pole or Running Beans}

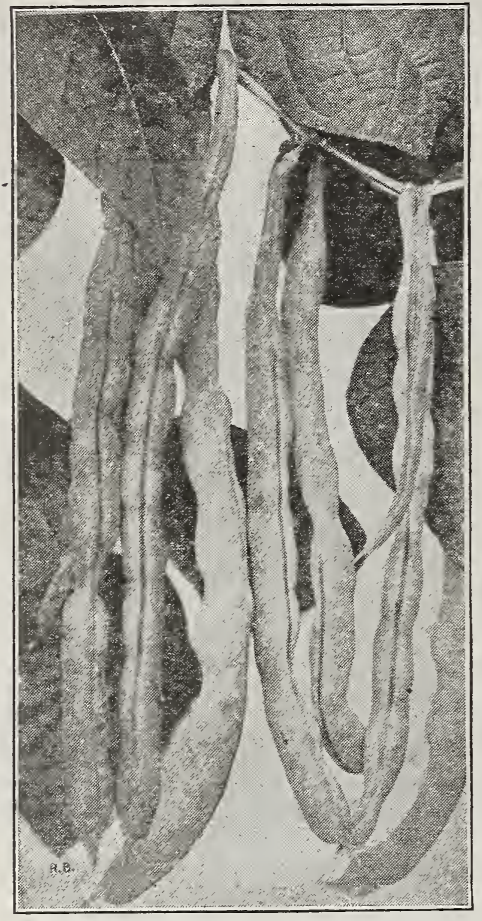

Kentucky Wonder

KENTUCKY WONDER - Brittle, stringless, meaty, delicious flavor. The plants are vigorous climbers; pods are borne profusely in clusters; they average from 7 to 9 inches long; are of attractive green color; round and very brittle when young. If the beans are picked as they mature, the vines will keep on bearing until killed by frost. Pkt., 10c; lb., 40c, postpaid. By freight or express, 35c lb.; 10 lbs., $\$ 2.75$.

WHITE GREASEBACK-Large, long pods, growing in clusters of from 6 to 12, of a silvery green, of the best quality of snaps. A good cornhill bean. Pkt., 10c; lb., 35c, postpaid.

\section{Dwarf Lima Beans}

BURPEE'S BUSH LIMA-The stout, erect bushes grow from 18 to 20 inches high and 2 to 3 feet in diameter. They are laden with large luscious beans. Pkt., 10c; lb., 40c, postpaid. By freight or express, lb. 35c.

HENDERSONS BUSH LIMA - Always early on the market and therefore, sure of a good price. This is the earliest variety, being fully two weeks ahead of any other sort in maturing . The City Farmer, anxious for an early taste of fresh butter beans on his table, and the Country Farmer keenly alive to the high prices paid for early vegetables, will both appreciate this bean. This is one of the few varieties that acclimates itself to both north and south. The beans are small and very fine for canning. Pkt., 10c; lb., $40 \mathrm{c} ; 10 \mathrm{lbs} \$ 3.00$

\section{JACKSON WONDER BUSH LIMAS-} This is the most productive and earliest of the Bush Limas. It is of true bush form, about 2 feet high, bearing greatest profusion of broad, flat pods, each having from 3 to 5 medium-sized flat, handsomely speckled beans, which cook quickly and are of superior flavor. A variety that will please everyone. Pkt., 10 ; lb., 40c, postpaid. By freight or express lb., 30c; $10 \mathrm{lbs}$., $\$ 2.75$.

\section{Pole Lima Beans}

GAROLINA OR SIEVA POLE - (Small White Lima)-Vigorous variety; very early and productive. Pods are short, flat and curved; beans white, small, and kidney-shaped. Pkt., $10 \mathrm{c}$; lb., 40c, postpaid. By freight or express, lb. $35 \mathrm{c}$.

KING OF THE GARDEN - (Large White Lima)-An improved strain of the large white, of more prolific character and with larger pods and beans. Large early crop that bears until frost. Only two plants should be allowed to one hill. Pkt., 10c; lb., 40c, postpaid; by freight or express, 35c per lb.

SPECKLED POLE LIMA-The most prolific of the Pole Limas. It blooms and bears profusely all through the season. Seeds are about the size of the Sieva, but are speckled white and brownish red. Pkt., 10c; lb., 35c, postpaid. By freight or express, lb., 30c; $10 \mathrm{lbs}$. , $\$ 2.50$.

If you want one peck (15 lbs.) or more Beans, write for prices. 


\section{BEETS}

Beets grow in moderately light, sandy soil. For very early crops, sow Crosby's or Eclipse in hot-beds and transplant the seedlings as soon as the weather is warm enough into open ground; for regular crop, plant outside as soon as the ground is in good condition; plant in drills 12 to 15 inches apart and cover about 1 inch deep. When the seedlings are 4 to 5 inches high, thin them out to stand 4 to 5 inches apart in the row. For winter crops, sow the improved Long Dark Blood in June. An ounce of seed will sow 50 feet of drill; 5 to 6 pounds to the acre.

GRIMSON GLOBE-Extremely handsome; early normal crop variety of medium size. The roots are almost globe-shaped and free from rootlets, leaving the skin entirely smooth. The flesh is of the finest quality - a rich blood red, slightly zoned, and always sweet and tender. Unequaled for table use and market. Pkt., 10c; oz., 15c; $1 / 4$ lb., 30c; lb., 80c, postpaid. By freight or express, per $1 \mathrm{~b} .75 \mathrm{c}$.

DETROIT DARK RED-Very popular sort used extensively by market gardeners as well as private planters. It matures early, and the roots are of splendid shape and good color. The tops are small and upright-growing, which makes possible close planting. The roots are globular and smooth, the skin is dark blood red, the flesh red with lighter zones. The beets are very tender, firm and crisp, and remain so for a long time. Pkt., 10c; oz., 15c; 1/4 lb., 30c; lb., 80c, postpaid. By freight or express, $70 \mathrm{c}$ per lb

ECLIPSE-Globe-shaped deep red roots, with sweet, fine-grained flesh; fit for use a long time. Pkt., 5c;. oz., 15c; $1 / 4$ lb., 25c; lb., 75c, postpaid. By freight or express, $70 \mathrm{c}$ per $\mathrm{lb}$.

IMPROVED LONG DARK BLOOD-Excellent for winter use, as it is a good keeper; flesh firm, juicy, and tender. Pkt., 5c; oz., 15c; $1 / 4 \mathrm{lb}$., 25c; lb., 80c, postpaid. By freight or express, $75 \mathrm{c}$ per $\mathrm{lb}$.

GROSBY'S EGYPTIAN-The market gardener's favorite. Fine, globe-shaped roots. Pkt., $10 \mathrm{c} ;$ oz., 15c; $1 / 4$ lb., 25c; lb., $75 \mathrm{c}$; postpaid. By freight or express, $70 \mathrm{c}$ per $\mathrm{lb}$.

EARLY BLOOD TURNIP-Coming in at the same time as the small, flat Egyptian, it is much larger and almost globe-shaped-a much better beet for every purpose. It is fine-grained, very tender, and of good, sweet flavor. The color of the flesh is a rich red, tinged with dark crimson. The roots remain in fine condition a long time after maturing. We highly recommend this as the best quality table beet. Pkt., $10 \mathrm{c}$; oz., 15c; $1 / 4 \mathrm{lb} ., 25 \mathrm{c}$; lb. $75 \mathrm{c}$, postpaid. By freight or express, 70c per lb.

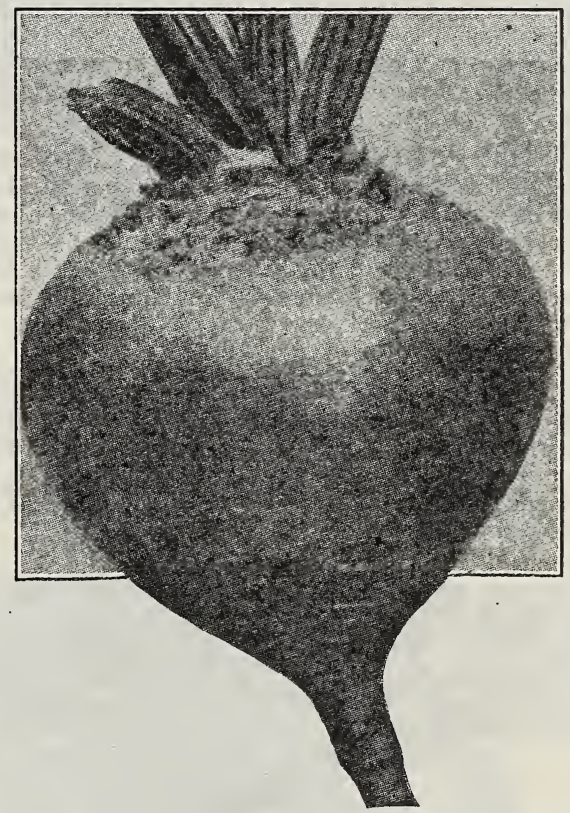

SWISS GHARD OR SPINACH BEET This delicious and useful vegetable should be in every garden and on every market stall. It is really two distinct vegetables. First the leafy part of the foliage is cooked and served the same as spinach, whilethe stalks are cooked and served with drawn butter, like tender asparagus. It grows about $2 \frac{1 / 2}{2}$ feet high. The stalks are thick and broad like rhubarb; the leaves are large and heavily crumpled, like Savoy spinach. Crisp and tender, pleasing flavor.

Pkt., 5c; oz., 15c; 1/4 lb., 30c; lb., 85c, postpaid. By freight or express, $75 \mathrm{c}$ per $\mathrm{lb}$.

ROOT GROPS FOR STOGK AND POULTRY-Mangel Wurzels and Sugar Beets are listed under Farm Seeds. See Page No. 56 of this catalog.

Spray or dust to reduce damage done to your plants by Aphis, Red Spider, Mealy bugs and Black bugs-See pages 44-58-59 for Insecticides, Fungicides and Sprayers. 


\section{BRUSSELS SPROUTS}

Brussels sprouts are a very delicate vegetable, and deserve a more general cultivation than they receive. The plant belongs to the cabbage family and should be grown and cultivated like miniature cabbages. Very hardy; improved by frost. An ounce will produce 2,000 plants.

DWARF IMPROVED-Bearing a small crop of small, solid, and tender heads. Pkg., 5c; oz. 15c, postpaid.

\section{CELERY}

Seed should be sown in February in hot-heds or in flat boxes filled with clean, mellow loam, with about $1 / 8$-inch of fine so il or sand, pressing it down firmly. Keep the soil moist constantly. When plants are fairly out of the seed leaf, transplant into another box or bed, or thin out to 2 or 3 inches apart. Plant into the open ground by the last of May or the beginning of June. One ounce will sow 300 feet of drill.

White Plume-The earliest and most easily blanched sort. While the inner stalks and heart are of pure white color without being blanched, yet the outer stalks should be tied up and the soil drawn around them, so as to produce attractive bunches. Fine for family use and the local markets. Pkt., 10c; oz., 30c.

Golden Self-Blanching-The plants are compact, semi-dwarf habit and form numerous stalks. They are heavily ribbed, of golden ye ow color, very crisp and tender. Pkt., 10c; oz., $40 \mathrm{c}$.

GELERIAC, OR TURNIP-ROOTED GELERY-Pkt. $10 \mathrm{c}$.

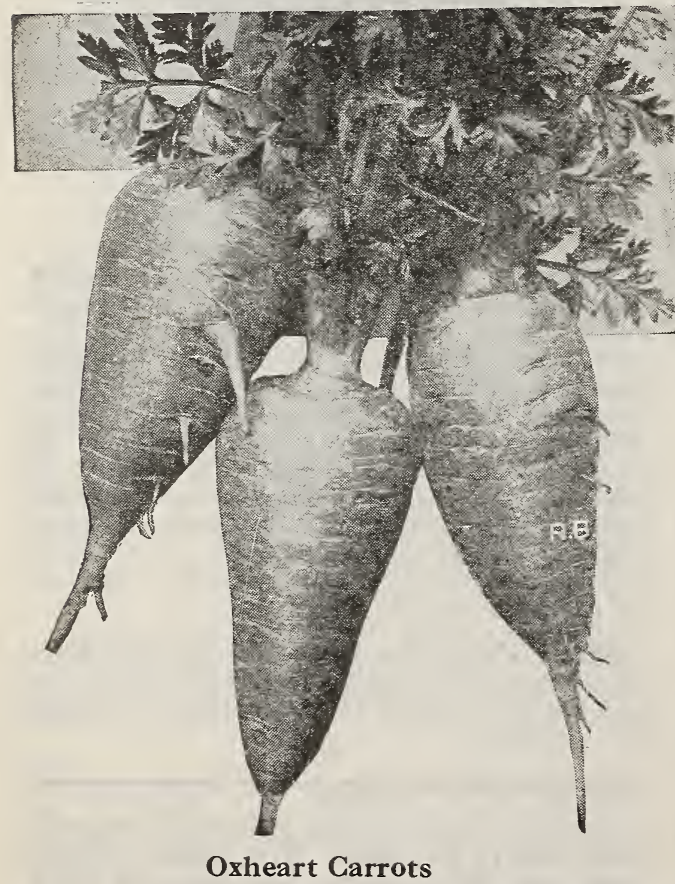

\section{GARROTS}

Carrots are said to be a beauty food. We should not like to suggest that you need to grow any for that reason, but we are quite sure that it will be of more service in this way to grow and eat a few carrots than to use a quart or so of beauty tonic.

There is no vegetable more wholesome than the carrot. It is easily grown and easily prepared for the table. The City Farmer will appreciate a row or two of carrots in his garden. The country farmer or the gardener know well the market demands for carrots.

Carrots grow best in rich, deep, sandy loam, well pulverized and deeply cultivated. Sow in March or April, in drills 15 to 18 inches apart and about $1 / 2$-inch deep, thinning out the seedings to 4 inches in the row. One ounce will sow 100 feet of row; 3 or 4 pounds to the acre.

Early Scarlet Horn-This variety is the first ready for the table in the home garden. The earliness of it makes it very valuable for growing under giass. The tops are small, dark green. The orange-red roots are short and topshaped, and when picked while young they are very tender. Pkt., '10c; oz., 20c; $1 / 4$ lb., 50c.

Danvers Half Long-An excellent market variety of medium size. The roots are of a rich orange-red color, smooth, and very handsome. Produces a very large crop. Pkt., 5c; oz., 10c; $1 / 4$ lb., 25c.

Long Orange-The best late variety for general field culture. It keeps very well, and is therefore excellently adapted for winter use. Pkt., 5c; oz., 15c; $1 / 4$ lb., 30c.

Oxheart, or Guerande-Of fine table quatities. It is the most desirable sort for growing in soils too hard and stiff for the longer varieties as it does not grow over 6 inches long, and is easily pulled by hand. Pkt., $10 \mathrm{c} ;$ oz., $15 \mathrm{c} ; 1 / 4 \mathrm{lb}$., 30c.

Market gardeners give our seeds the preference. In buying get the best, even at higher prices. You get results.

Send in a photo of your garden and write how things are growing. Your success is ours. 


\section{Carrots---Cont.}

Early Chantenay-A fine bunching carrot. One of the best early sorts, maturing between the Oxheart and Danvers. The carrots row about 6 inches in length, stump-rooted, very smooth, deep red, fine-grained, sweet, and sugary. Market gardeners should grow these for their main early crop. Pkt., 5c; oz.: 15c; $1 / 4 \mathrm{lb}$. 30c, postpaid.

\section{Cabbage}

Soil for cabbage should be a rich heavy loam, with good drainage. Such a soil when supplied with a liberal quantity of stable manure and complete fertilizers will produce excellent crops.

\section{Extra Early Varieties}

True Early Jersey Wakefield... Small, cone-shaped head; matures in from 90 to 100 days after planting. Pkt., 10c; oz., 15c; 1/4 lb., $50 \mathrm{c}$, postpaid.

\section{The Charleston, or Large Wake-} field-The best large early cabbage. This cabbage has created a sensation with the cabbage growers all over the country on account of the decided advantage it has over all other sorts. It can be the first variety sent to market, and on account of its handsome appearance will invariably bring the tip-top prices. If, however, the early market prices are low, it can be safely left standing in the field to mature into an extra large, compact, solid, magnificent cabbage, which has never failed to attract the admiration of the most skilled gardeners, and always brings better prices than any other sort harvested at the same time. Our stock is thoroughly reliable. Pkt., 10c; oz., 15c; 1/4 lb., 50c.

Copenhagen Market-The earliest large round-headed cabbage. Very popular with market gardeners; excellent for home gardens. An extra early summer cabbage, matures fully as early as the Early Jersey Wakefield, but produces larger heads, of ten averaging 10 pounds or more. The heads are ball-shaped, mild and firm, with small core, and of splendid quality. Leaves are of light green color, tightly folded together, forming a very compact head. You should give this cabbage a place in your garden. Pkt., 10c; oz., 30c; $1 / 4$ lb., 60c.

\section{Second Early Varieties}

Allhead Early-An early flat variety, with remarkably solid heads, which have few outside leaves. It is practically all head. While it is really a typical summer cabbage, it is fully as good for winter use, being a good keeper. The heads are of uniform size, uniform in color and of excellent flavor. Pkt., 5c; oz., 15c; 1/4 lb., 50c, postpaid.

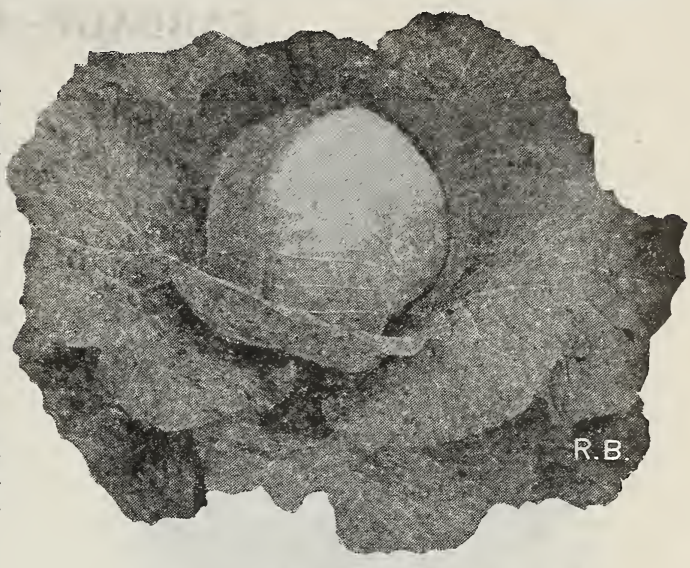

Copenhagen Market Cabbage

Early Flat Dutch-A selected strain; forming large flat heads, weighing at times 10 to 12 pounds. It is a sure header and well adapted for forcing. We consider it the best cabbage for planting in the South. Pkt., 10c; oz., 15c; 1/4 lb., 50 c, postpaid.

All Seasons--One of the best of its class. Ready for the market only a few days later than the Early Summer and is much larger. The heads are firm, solid, and of good flavor. Pkt., $10 \mathrm{c}$; oz., $15 \mathrm{c}$; $1 / 4 \mathrm{lb}$., $50 \mathrm{c}$ postpaid.

\section{Late Varieties}

Premium Late Flat Dutch-Of good flavor and verry tender; among the earliest of the winter cabbages. Pkt., 10c; oz., 15c; $1 / 4$ lb., 50c.

American Perfection Drumhead Savoy-Too little attention is paid to the Savoy cabbage in this locality, as for home gardens it is unquestionably the most desirable of all cabbages. It is used almost entirely for late planting and attains its greatest perfection in flavor after frost, when it becomes as tender and even more delicious than califlower. The heads are of medium size, borne on short stems and not as large as the ordinary late cabbage, hence it will stand closer planting. Pkt., 10c; oz., 15c; $1 / 4 \mathrm{lb}$., 50c, postpaid.

Surehead-Strain of flat Dutch; remarkable for its heading qualities; keeps well and is good for shipping. The heads are of uniform size, firm, solid, and of good color. Pkt., 5c; oz., 15c; 1/4 lb., 50c, postpaid. 


\section{CABBAGE-Continued}

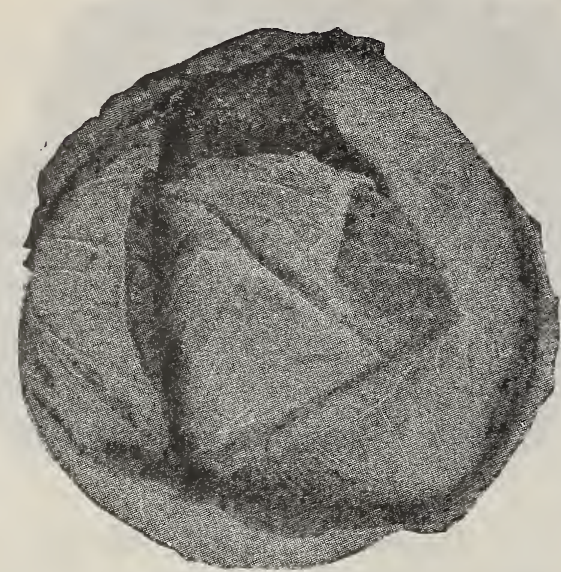

Farly Dwarf Flat Dutch

Hollander, or Dutch Ballhead-.Of vigorous, compact growth, with stem rather longer. Pkt., 10c; oz., 40c; $1 / 4 \mathrm{lb}$., $\$ 1$, postpaid.

Mammoth Red Rock-The best red cabbage for pickling or table use. Heads average over 10 pounds, always of rich red color; excellent flavor and a sure header. Give it a trial. Pkt., 10c; oz., 40c; 1/4lh., $\$ 1.00$, postpaid.

\section{COLLARDS}

A kind of cabbage, growing 2 to 3 feet high. The central leaves often used for greens. Collard seed is started under glass or in the open. Plants should be cultivated like cabbage.

Improved Georgia-Plants may be pianted at almost any time of the year, and is much hardier than cabbage. The plants may stand as close to each other in the field as 8 inches. Pkt., 5c; oz., 15c; 1/4 lb., 25c, postpaid.

SLUG SHOT kills cabbage worms, also cucumber, melon, squash, and potato bugs. Contains nothing in the least injurious. 5-1b package, not prepaid, 65c.

\section{Gentlemen:}

From the seed I purchased from you last year (Darso), I have a good field, every seed seemed to grow. Now I am wanting to sell you either part or all of the crop. We ordered a bushel of seed and have a peck left. We have never planted cotton and if I can sell this crop and make as good profit on it as people do on cotton, it will be a good "trade last" for Darso.

Myself and children do the farming and we raise bumper crops. Had the finest wheat around here, over 31 bushels to the acre. People are asking the children now

\section{Pe-Tsai Chinese or "Celery"}

Cabbage-The Chinese or "celery" cabbage, has attained great popularity in the last two years. Pe-Tsai produces beautiful, crisp, celerylike heads that blanch easily and resemble a giant Cos lettuce. As a salad, it rivals the finest lettuce, while cooked like cabbage or spinach it makes delightful "greens." Early sowing is not recommended, as during hot weather it has a tendency to run to seed without heading. Sow seed in any good soil the first of August, making rows 24 to 36 inches apart and thinning to 15 inches apart in the row. Pe-Tsai will not stand frost, so that heads intended for winter use should be stored in a cool frost-proof cellar. Pkt. $10 \mathrm{c}$; oz., 25c; $1 / 4 \mathrm{lb}$., 70c. postpaid.

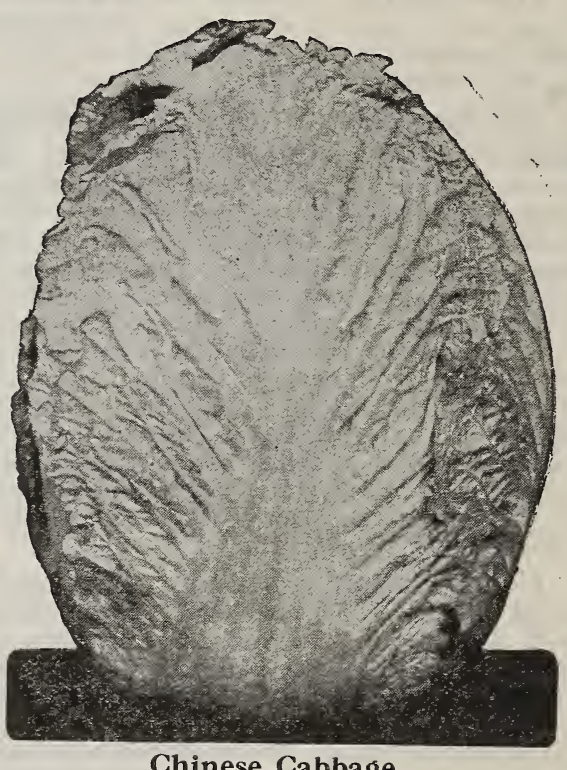

about the field of Darso, want to know what kind of kafir it is. Say! the heads look half as long as the stalks. If you wish to buy the Darso, write us when to cut and method of caring for the seed, if you care to. I will have to sell the Darso soon and buy other feed to use as it is all we have to depend on. Have a small patch of milo but none to sell. Would appreciate an answer as to what price you would give per pound for the seed.

August 19, 1924.

Mrs. Rachel Rice, Watonga, Okla., R. 2.

-For Darso, See Page 54 of this catalog. 


\section{SWEET}

\section{PERFEGTION BRAND SWEET CORN IS} NORTHERN GROWN

Corn like anything else well worth having, takes a little care to produce. A few rows of corn will supply the average home with plenty of fine roasting ears and enough over for canning and drying to last through the winter.

Be sure and plant Sweet Corn every ten days or two weeks and you will have a continuous supply of table corn in the right stage to enjoy the eating of it. Wait until the ground is warm to plant Sweet Corn. A prolonged cold, rainy spell may cause it to rot in the ground. Extra Early and Early Adams Corn may be planted as early as any field corn, Golden Bantam will also stand colder ground and weather than the other varieties. Largest yields are secured by planting rows 3 to 4 feet apart and drilling seed every eight or ten inches apart in row, cover two inches. One pound will make about 1000 plants-10 pounds will plant an acre. Cultivation is the same as for field corn, except it should not be permitted to get weedy.

Adams Extra Early-A great favorite with those who wish the first corn of the season. Produces short ears, filled with tender, white kernels of fine flavor. Pkt., 10c; lb., 30c; postpaid. By freight or express, lb., 25c; 10 lbs., $\$ 1.75$.

Adams Early-Has larger ears than the preceding; very popular in the South. Pkt., 10c, lb., 30c; postpaid; by freight or express, lb., 25c; 10 lbs., \$1.75.

Golden Bantam-A new early sweet corn, considered by many people the richest and sweetest of all corns. Some of our customers who prefer this sort to all other kinds are planting it at regular intervals all during the season, so they may have a continued supply for their table. The stalks are of medium size, with heavy foliage, for forage. It may be planted early and as late as July 20th in the Middle States. The ears are borne two to a stalk about 6 inches in length and are eight-rowed. The kernels are of golden yellow color, which at first gives the impression of field corn. However; as soon as tasted there is immediately a call for more. Our seed has been especially selected for table use. Pkt., 10c; lb., 35c; postpaid. By freight or express, lb. 30c.; 10 lbs. $\$ 2.00$.

Early Minnesota-One of the earliest sort on our list. Of dwarf habit, but very productive; small ears, with eight rows of very sweet and tender kernels. Pkt., 10c; lb., 35c, postpaid.

Stowell's Evergreen-The ears are large; have fifteen or more rows of deep, luscious kernels, and remain tender and fit for use longer than any other sort. Pkt., 10c; lb., 35c, postpaid. By freight or express, lb., 30c; 10 lbs.,\$2.25.
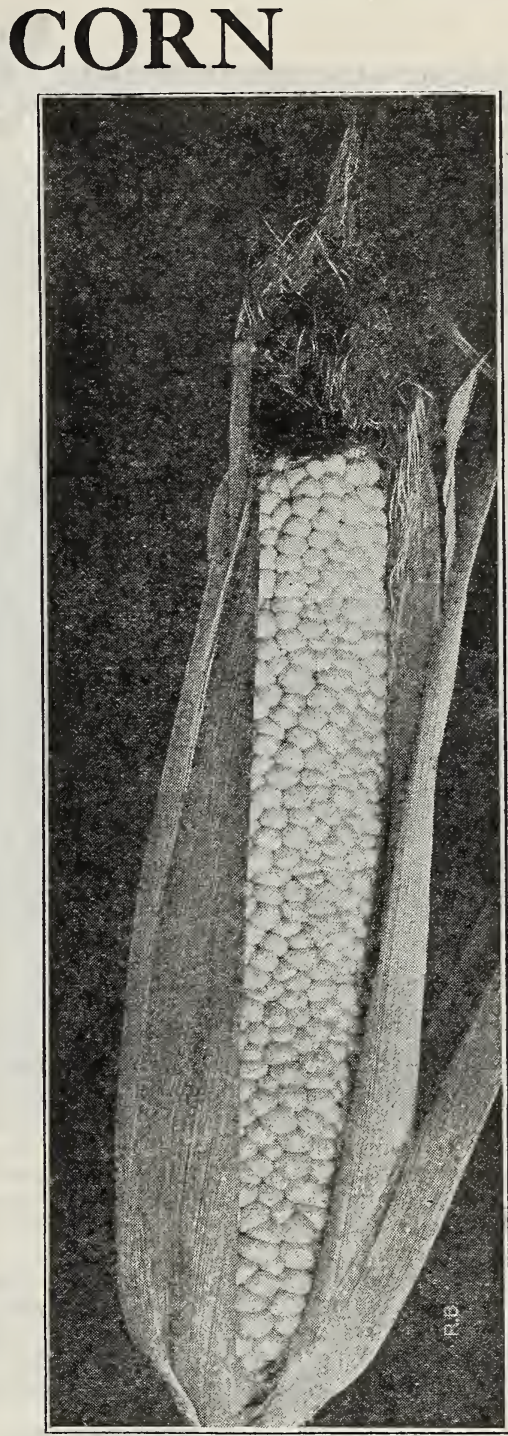

Country Gentleman Sweet Corn

Country Gentlemen-The most delicious of the late sorts. For family use it is unequaled. The medium-size ears are covered with irregularly arranged, deep, sweet kernels. Very prolific, and well liked in some localities, where it is sold on the market as the "Shoe Peg." Pkt., 10c; lb., 40c, postpaid. By freight or express, lb., 30c; 10 lbs., $\$ 2.50$. 


\section{EGG PLANT}

Seed should be started in February, in boxes in the house. Always keep the grourd warm and moist, and protect the young plants. Transplant into a rich, loamy soil when all danger of frost is past. One ounce will produce about 1,000 plants.

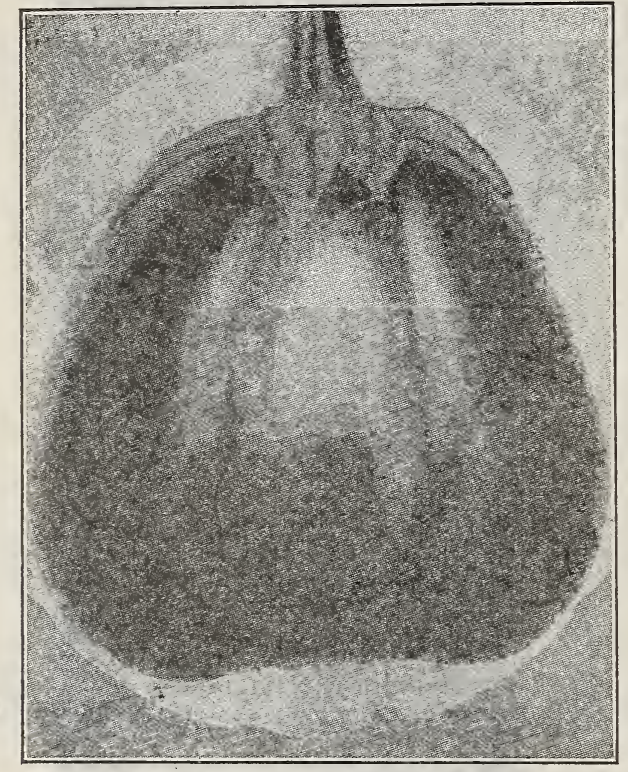

Black Beauty

New York Improved Purple-One of the best and largest varieties in cultivation. Our strain of this variety is especially fine. The plant is robust, low-growing, branching freely, and bears long, oblong-shaped fruits. There are many varieties of egg plant offered, but we think this kind better than any other. Pkt., 10c; oz., 50c, postpaid.

Black Beauty---Ten days or two weeks earlier than the preceding, with fruits just as large, of a uniform and rich, lustrous black color. Fruit develops very quickly, and planters will be pleased with it. Pkt., 10c; oz., 50c, postpaid.

\section{GAULIFLOWER}

It requires a cool, moist season for its best growth, a constant supply of soil-moisture, and rich, loamy land, well fertilized. Cultivation is the same as for cabbage. One ounce will produce from 800 to 1,000 plants.

Early Snowball-Under favorable conditions, every plant produces a magnificent white head of fine quality. Pkt., 10c.

\section{CRESS}

Sow curled or pepper grass thickly in shallow drills every two weeks. It should be cut often, and will continue to grow. Useful for salad and garnishing. One ounce of seed will sow 200 feet of drill of the pepper grass.

Extra Curled or Pepper Grass--Quick-growing and crisp, pungent flavor. Does well in dry soil. Pkt., 5c; oz., 20c.

\section{CORN SALAD}

Used for "greens" like Spinach or as a salad. Can be sown in the spring and fall. Succeeds best when sown in the early spring and in August. Can be sown in September and wintered like spinach if given a little protection.

Large Round Leaved-The best variety. Matures in four or five weeks. Pkt., 10c; oz., $15 \mathrm{c} ; 1 / 4 \mathrm{lb} ., 35 \mathrm{c}$.

\section{DILL}

Every year there is such a demand for green dill that the supply is short of the demand. Plant in any quantity, from ten feet square to fifty feet square, but not more. Make several plantings to have it for market almost constantly and sell what you can of the green dill and dry the balance. First planting may be made about May first. Packet will plant three feet square; an ounce will plant ten by fifteen feet. Pkt.,10c oz., 30c.

\section{ENDIVE}

Endive is an excellent autumn and winter salad. Sow late in spring or even July in shallow drill 15 inches apart. When plants are strong thin out to about 1 foot apart. To blanch, gather up outer leaves over certer of plant and tie together at the tips. One ounce will sow 100 feet of drill.

Improved Green Curled - Finely fringed leaves of bright green color; tender and crisp when blanched. Pkt., 10c; 0z., 15c; $1 / 4 \mathrm{lb}$., $40 \mathrm{c}$, postpaid.

\section{GARLIC}

Used for flavoring soups, sausage, etc. It is propagated by division of the roots into small parts. The bulbs are gathered in August in the same manner as onions. $1 / 2$ lb., $25 \mathrm{c}$; lb., $45 \mathrm{c}$, postpaid.

\section{HORSERADISH}

Grown for its roots, which have a pungent, mustard-like flavor. Small pieces of roots, 4 to 5 inches long, are planted for propagation. Plant in rich ground-the richer the better. $35 \mathrm{c}$ per dozen., $\$ 2.00$ per hundred.

Don't let bugs or plant lice eat up either the flower or vegetable plants you have started. Spray with Black Leaf $\mathbf{4 0}$ for plant lice, and with Bordeaux Mixture for rust, blightor fungus. We have all kinds of sprayers and remedies. See page 44, 58 and 59. 


\section{GUCUMBERS}

Plant as soon as the.weather has become settled and warm, in hills 4 feet each way. Cucumbers succeed best in warm, moist, rich, loamy soil. Prepare the hills by mixing a shovelful of well-rotted manure with the soil; plant the seeds about 1/2-inch deep. When all danger of insect attack is over, thin to about three or four of the strongest plants to the hill. Do not allow any fruit to ripen on the vines, as this will cause them to stop bearing.

Early Fortune-The fruits are almost cylindrical in form, slightly pointed at the ends, smooth and of deep rich green color, marked with distinct light green lines at the stem end; of very attractive appearance, very productive and very early. Pkt.,10c; oz., 20c; $1 / 4$ lb., 40c lb. $\$ 1.25$ postpaid.

Early Cluster -Extra prolific sort; setting its fruits in clusters of two or three. The fruit is a dark green, short and particularly suitable for pickles. Pkt., 10c; oz., 15c; $1 / 4 \mathrm{lb}$. $35 \mathrm{c}$, postpaid.

Chicago Pickle-Largely used by pickle manufacturers. Prolific, short, with fruit of medum size, dark green color, and with proninent spines. Pkt., 10c; oz., 15c; 1/4 lb., 35c, postpaid.

Japanese Climbing-The strong vines throwing out numerous tendrils, can be trained upon a trellis or poles, which will insure earlier ripening and a straight, handsome form in the large fruits. Pkt., 10c; 07., 25c, postpaid.

Perfection Hybrid White Spine-..This splendid new cucumber is the result of a cross between an English forcing variety and our American sort, Evergreen White Spine. The cukes are much darker in color than any White Spine variety, holding this color remarkably well, and also being of longer and thinner shape. It is the id eal $\mathrm{market}$ cucumber, producing under ordinary field culture beautiful fruits equaling in every way the hot-house grown product. We offer select Michigan grown seed. Pkt., 10c; oz., 40c; 1/4 lb., $\$ 1 ;$ lb. $\$ 3.00$ postpaid.

West Indian Gherkin--A very prolific, small-fruited variety, used exclusively for pickling. It is not properly a cucumber, and is of no value for slicing The fruits are 2 to 3 inches in length, thick and rounded, closely covered with spines; vines rather slender, with small foliage, but of strong growth. Pkt., 10c; oz., $20 \mathrm{c} ; 1 / 4 \mathrm{lb}$., $40 \mathrm{c}$; lb., $\$ 1.50$, postpaid.

Improved Long Green-Most widely cultivated sort; unsurpassed for general use. The cucumbers average 10 inches long when fully developed, and are fine for slicing. The smaller fruits make excellent pickles. Pkt., 10c; oz., 20c; $1 / 4$ lb., 50c, postpaid.

Davis Perfect-A superb variety. Dark glossy green, slim and symmetrical, with an average length of 10 to 12 inches. They hold color till nearly ripe when they turn white without a yellow streak on them. Quality fine as seeds are very soft when fit for table use. Very tender, brittle, and of exceptional flavor. Early

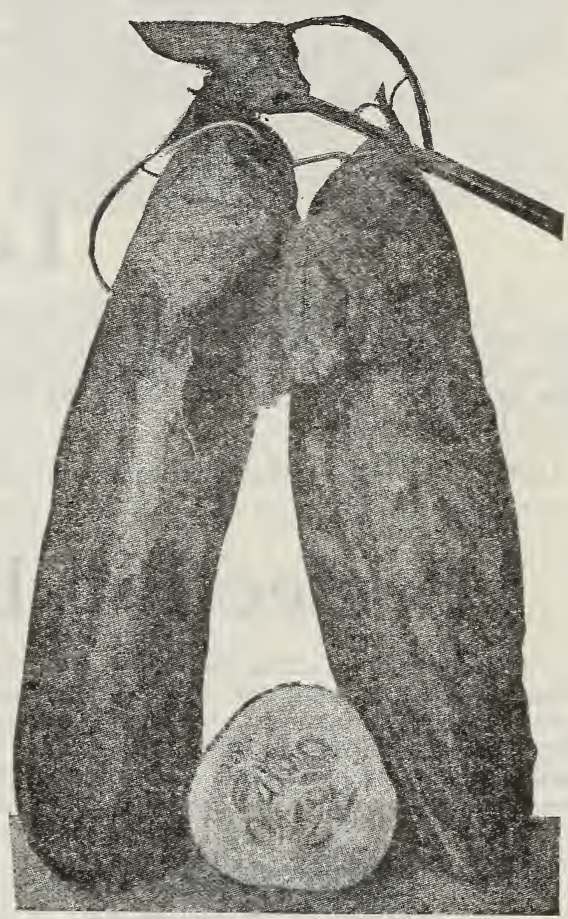

as earliest strain of white spine and out-yields all others. Pkt., 10c; oz., 20c; $1 / 4$ lb., 50c.

Improved Klondike White Spine-The vines are very vigorous and productive; the fruit is of an attractive, deep glossy green color, with light spines running from blossom end. Most desirable for the market use. Pkt., 10c; oz., $15 \mathrm{c}$; $1 / 4 \mathrm{lb}$., $35 \mathrm{c}$, postpaid.

\section{KALE OR BORECOLE}

Loose, curly-leaved type of the cabbage family; particularly noted for its hardiness. It makes excellent tender greens for winter use. In the South the most hardy variety remains in the open ground all winter. Cultivated the same as cabbage One ounce of seed is sufficient for 200 feet of drill.

Early Curled Siberian-One of the most popular varieties for home use and home market. The plant is dwarf, spreading, and very hardy, standing the winter without protection. The leaves are green, slightly tinted with purple, and of superior quality. Oz., 10c; $1 / 4$ lb., 25c; lb., 75c, postpaid. By express, $65 \mathrm{c}$ per pound. 


\section{Kohl Rabi}

Grown for its thick, bulb-shaped stalks, wnich while young, are prepared in the same manner as turnips, and which furnish a most desirable vegetable. One ounce of seed will drill 200 feet.

Sow the seed in the spring in drills $1 / 2$ of an inch deep and 2 feet apart and when the plants are a few inches high thin to 15 inches. Cultivate same as for beets.

Early White Vienna--Equally good for forcing or cultivation in the open ground; has very short tops; flesh is white, tender, and of excellent table qualities. Pkt., 5c; oz., 20c, postpaid.

Early Purple Vienna-Similar to the preceding sort, except in color, which is a bluish purple. Pkt., 5c; oz., 20c, postpaid.

\section{Leek}

A very delicately flavored member of the onion family. The leafy portion of the plant is used for flavoring soups or boiling with meats while the white, fleshy stems are boiled and either served with cream dressing or as a salad with vinegar and salad oil. Leeks prefer a rich, light soil. Cultivate the same as onions. Filling up will blanch the stalks and improve their quality. One ounce will sow about 100 feet of drill.

London Flag-A strong growing sort; hardy and excellentfor winter. Pkt.,10c;oz.,25c,pnstpaid.

\section{Perfection Brand Lettuce}

This is a salad plant of first rank. It is extensively forced in green-houses and in hot-beds in the winter and early spring and in cold-frames and out of doors later. Out of doors it is planted in succession from spring until fall. It grows better in clay, loamy soil made rich with barnyard manure. The plants should be started 12 inches apart each way. Frequently it is grown between rows of other plants like cabbage, and is matured and removed long before the other plants need the space. One ounce will plant 150 feet of drill.

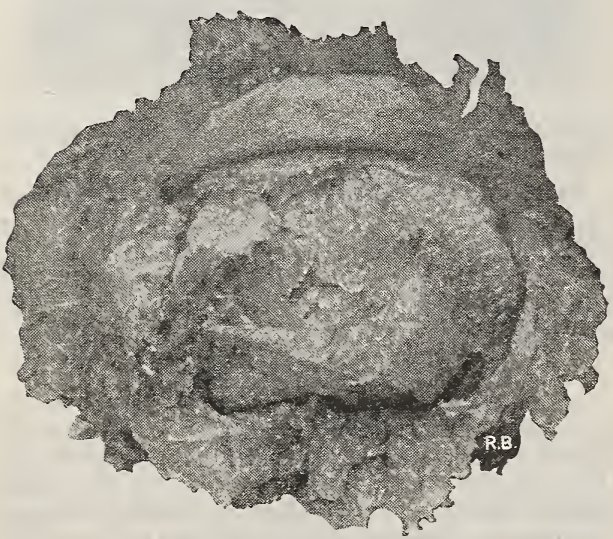

Head Lettuce

Improved Hanson-One of the best for growing during the hot summer months, as it will stand heat and dry weather to perfection. The large, solid heads weigh sometimes 2 or 3 pounds. They are of light green color outside and white within-tender, crisp, and of fine flavor. Pkt., 10c; oz., 20c; $1 / 4$ lb., 40c, postpaid.
Big Boston-.-Very distinct variety; grown largely in the South as a winter lettuce. When grown in cold-frames or houses, it forms large, solid heads, with broad, comparatively smooth and thin leaves. They are of a light green color and quite tender when well grown. Outside it is a less distinctive heading sort, the plants bearing vigorously, growing to a good size and forming loose heads. Pkt., 10c; oz., 20c; $1 / 4 \mathrm{lb}$., $50 \mathrm{c}$, postpaid.

Prize Head-Forms large, loose heads, which will not stand shipment to distant markets. The outer leaves are bright and green, shaded with brownish red. They are large and thin, attractively curled, and very tender. Pkt., 10c; oz., $20 \mathrm{c} ; 1 / 4 \mathrm{lb}$., $40 \mathrm{c}$, postpaid.

Paris White Cos-The Cos lettuce differs entirely in shape from the other varieties, the head being elongated and of a conical form, eight to $n$ in e in ches in height and 5 to 6 inches in diameter. The outer coloring of this variety is a yellowish green. To be had in perfection, it requires to be tied up, so that the center leaves may be blanched. Pkt., 10c; oz., 20 c; $1 / 4$ lb., 50c, postpaid. 


\section{LETTUGE-Continued}

Early Curled Simpson--Forms close compact bunches of effectively curled leaves. Pkt., 10c; oz., 20c; 1/4 lb., 50c, postpaid.

New York-A favorite variety. Heads very large, heavy and compact. Has a vigorous root system, which enables it to stand hot weather better than other varieties. Slow to run to seed and stands longer than some other sorts. The interior is beautifully blanched, creamy white, crisp and tender, and free from any bitterness. Pkt., 10c; oz., 30c; $1 / 4 \mathrm{lb}$., $\$ 1.00$, postpaid.

Denver Market-This is a fine, crisp, crimp-head variety. It has a slight tinge of red at the edge of the leaves. The ribs are a waxy white, being tender and free from bitterness. Pkt., 10c; oz., 20c; 1/4 lb., 50c, postpaid.

Black Seeded Simpson-Makes large bunches of curly, crisp leaves. Pkt., 10c; oz., $20 \mathrm{c} ; 1 / 4 \mathrm{lb}$., 50c, postpaid.

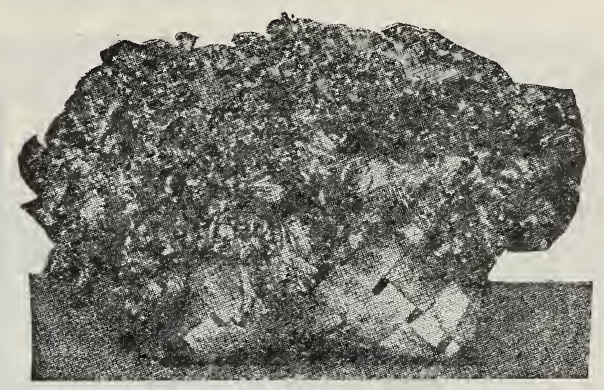

\section{Grand Rapids}

Grand Rapids-The well-known forcing variety for the Middle West, where the butterheads or cabbage varieties do not grow very well under glass. It is a loose-branching variety, forming no definate head; is extremely curly, and its light green color is very attractive. Pkt. 10c, oz. 20c, $1 / 4 \mathrm{lb} .50 \mathrm{c}, \mathrm{lb} . \$ 1.50$.

\section{PERFEGTION BRAND GANTALOUPES AND MUSKMELONS}

A warm, sandy loam is best for raising melons. Plant early in the spring, 8 seeds in each hill. After they are well started thin to about 3 strong plants to each hill. An ounce will plant 60 hills; 2 or 3 pounds to the acre. We strive to supply ruelon seed of the highest quality. We have them grown where they reach the highest point of perfection by the most reliable growers, and are in a position to offer strains far superior to the commonly sold commercial grades. Many testimonials from thoroughly pleased customers show that our efforts to supply only the best are appreciated.

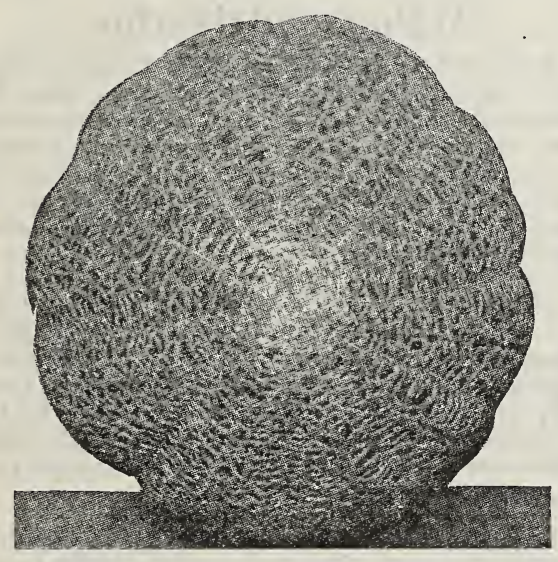

Pollock's Salmon Tint No. 10-25

Pollock's Salmon Tint No.10-25-This is the famous Cantaloupe grown so largely in California for the shipping trade. The melons run very uniform in size and the exceptionally heavy netting is laced and interlaced over the entire surface, making it an ideal shipper. The flesh is green, shading to salmon about the seed cavity, which is unusually small. The meat is solid and fine grained, flavor un. excelled. Our seed of this variety was grown at Rockyford, where it was first grown and developed. Pkt., 5c; oz., 15c; 1/4 lb., 35c; lb., $\$ 1.00$, postpaid. By freight or express, lb., 90c; $10 \mathrm{lbs}$., $\$ 7.50$. If you buy in larger quantities ask for special prices.

Osage, or Miller's Cream-One of the finest and most popular salmon fleshed Muskmelons. The fruits are large, usually nearly three times the size of the Rockyford, with skin moderately netted and of oblong shape. The flesh is of a rich golden color, very thick, fine grained and in flavor cannot be excelled. Especially well suited for heavy soil where other melons usually do not give good satisfaction, are also equally good for sandy soils. The seed we offer is very choice. Pkt., 5c; oz., 15c; $1 / 4 \mathrm{lb}$. 30c; lb., 90c.

Rocky Ford-This is the melon that made Rocky Ford famous. The vines are exceedingly healthy and vigorous, bearing an abundant supply of fruit throughout the season. The flesh is green, very deep, solid and sweet, and can be eaten close to the rind. The seed cavity is very small. Pkt., 5c; oz., 15c; 1/4 lb., 30c; lb., $90 \mathrm{c}$, postpaid. By freight or express, lib., 85c 10 lbs., $\$ 7.00$. 


\section{CANTALOUPES AND MUSKMELONS-Continued}

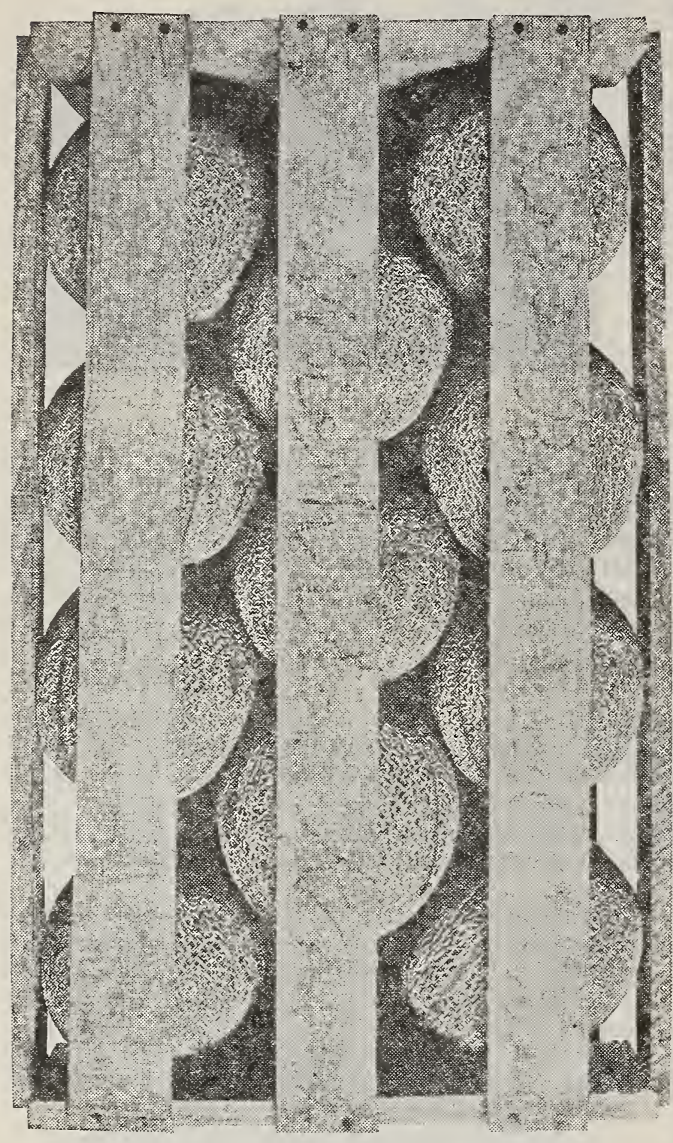

A Typical Crate of Edwards Perfecto

Edwards Perfecto-We consider its table quality equal to any cantaloupe on the market and superior to 97 per cent of all melons offered. The large pink-meated fruit was originated by one of the leading growers of Rocky Ford, Colorado, and this season the demand was larger than the supply. Edwards Perfecto is pink-meated, deliciously sweet, deep fleshed with very small seed cavity, the melon almost round, covered with deep silvery netting, shallow ribbed. It will make money for the market gardener and will command the respect and admiration of the home gardener who appreciates good things to eat. Pkt., 10c; oz., 20 ; $1 / 4 \mathrm{lb}$., 50c; lb., $\$ 1.25$.

Early Hackensack-Very early and reliable. Skin is green and thickly netted. Flesh light green. This valuable variety is ready for the market fully ten days ahead of the well-known Hackensack. Pkt., 5c; oz., $15 \mathrm{c} ; 1 / 4 \mathrm{lb}$., 25c; lb., 90c.

Improved Banana-Produces fruit of the finest quality, $1 \frac{1}{2}$ to $21 / 2$ feet long; rind thin and comparatively tough; flesh of a beautiful reddish salmon color, of excellent flavor; withstands the heat to perfection; fine fur family use. Pkt., 5c; oz., 15c; 1/4 lb., 40c, postpaid.

\section{Gold}

Gold Lined Rocky Ford-For shipping and for the home table this medium sized round, green meated sort is very desirable. The thick flesh is green with a clear gold tint next to the seed cavity. The skin is covered with a thick, gray netting. Pkt., 10c; oz., 15c; 1/4 lb., 50c; lb., \$1.25.

Honey Dew Melon-The fruits are of medium size, round or slightly oval, 5 to 6 inches in diameter and weigh about 6 pounds each. The skin is smooth with an occasional net and when fruits are ripe is creamy yellow in color. Flesh light emerald green, fine grained and of very sweet, sugary flavor. Rind thin but very firm and the fruits stand shipping remarkably well. If picked shortly before mature the fruits will keep for several weeks. Matures about two weeks later than Rocky Ford. Pkt., 5c; oz., 20 c; $1 / 4$ lb., 40 c; lb., $\$ 1.00$.

\section{Melon Cultivation}

It is just as essential in raising good melons that the ground be thoroughly and carefully prepared as that good seed be used. Good melons are dependent on rapid and continuous growth, and if the plant roots are not able to grow rapidly and obtain food, the plants are going to be checked, and the chances for a real first class melon crop are gone.

Besides the cultivation, the soil should be enriched by the application of plenty of well rotted manure or other fertilizer. For home gardens it may pay to throw a forkful of manure in each hill, but for general cultivation it is much better to have it well distributed over the whole field. The roots are long and will reach out several feet in every direction.

Keep lice under control by frequent application of Black Leaf 40 . The first spray should be made as soon as the third leaf appears, and as often as the lice reappear.

Keep the plant growing constantly. Without this the best of seed will not do you a bit more good than old cull seed. Any old seed, and any old piece of ground will grow a resem. blance of a melon but for first class, juicy fruit, good soil, good cultivation, and good seed are essential. 


\section{WATERMELONS}

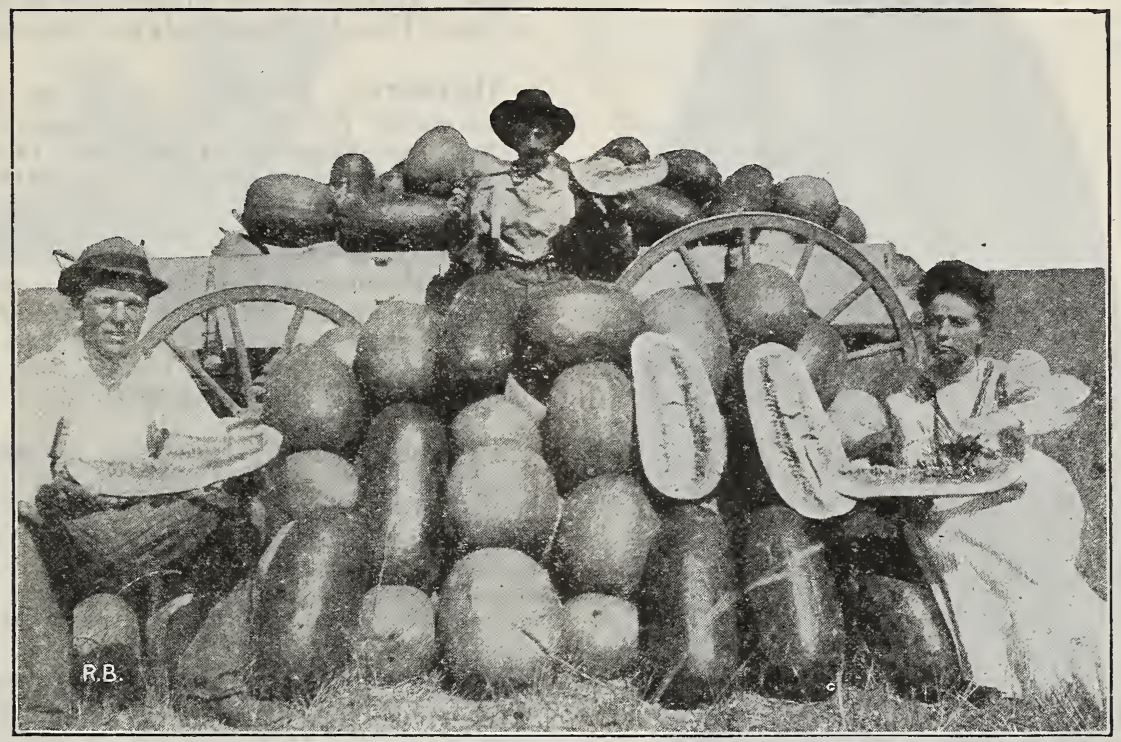

Our watermelon seed is grown especially for us in the South and selected from the very best melons. Southern-grown watermelon seed is always the best and the quality of the melons the very highest, as has been proven. Our sales on watermelon seed have shown a good increase every year, and we now supply several melon-growers' associations that buy in 100-pound lots or more. A trial order will convince you our seed is first-class in every respect.

Plant watermelons eight or ten seeds in a hill about 1 inch deep. After they are well started, thin out to two strong plants to a hill. Two shovelfuls of rich manure thoroughly worked into the soil beneath each hill will greatly increase the size of the melons.

All through this part of the Arkansas River Valley last summer the roads were lined for miles with Watermelons at almost every farmer's gate, which were in great demand bv automobile parties, who often made special trips from the cities to buy the fresh country melons. It is mighty good business training to teach the farm youth the value of a dollar and how to get it, by allowing hirn a space in the field in whichto grow melons and establish him by the side of the road in front of his house with a pile of melons of his own raising to sell to the city automobile parties.

Irish Grey - Is a distinctand very valuable melon, producing more good merchantable melons under the same conditions than any other variety, the eating quality is all that could be desired in a watermelon, the sparkling red flesh is very sweet and entirely free from hard centers or stringiness, yet the flesh is very firm and compact and will not break when sliced. The size is uniformly large. Color of rind, yellowish grey, and almost as tough as that of the citron, ripens earlier than Tom Watson, and will keep in good condition for a long time after picking and stand long distance shipping better than any other melon. Another important feature, the melon will not sunburn and will keep in good condition for several days in the sun after becoming ripe, while all dark melons will blister yellow on the top, which renders it unsaleable. Pkt., 10c; oz., 10c; 1/4 lb., 25c; lb., 80c, pustpaid.

THURMOND GRAY - It is a good producer, stands wet weather well, and so far has not been subject to the diseases that have damaged other melons. This new melon is long and thick. The rind is of a rich greenish-grey color, which makes it difficult to sunburn. It is wilt resistant. It is very uniform in growth, being the same size at each end, and makes the most perfect car pack of any of the shipping varieties. Pkt., 10c; oz., 20c; $1 / 4$ lb., 50c; lb., $\$ 1.50$, postpaid. 


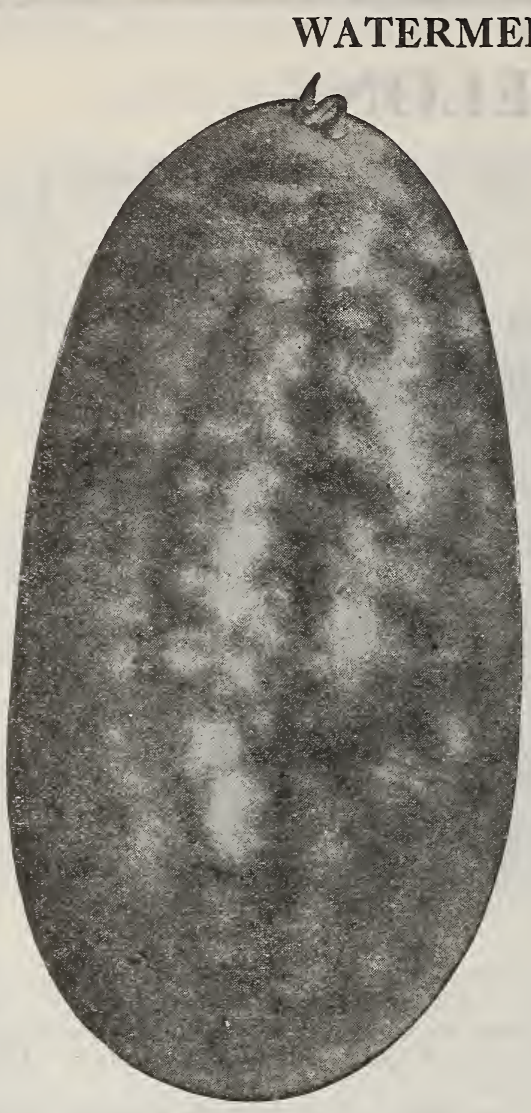

Alabama Sweet

Improved Kleckley's Sweet-One of the earliest best and sweetest-flavored melons in cultivation. On account of its thin rind, it will not stand shipment to distant markets, but it is the best that can be grown for the home and nearby markets. The skin is dark green. It is of symmetrical oblong shape, well rounded on both ends. The flesh is scarlet, firm, solid, and of delightful flavor. Pkt., 10c; oz., 15c; lb., \$1; 10 lbs., $\$ 9.00$, postpaid.

Alabama Sweet-This is a large, oblong melon; color dark green, with faint lighter stripes. Being of good size, though not ungainly, it is first class for shipping purposes. Its flavor is simply delicious; it is entirely stringless, and its outside appearance is very attractive. Its size and shape are such as to make it one of the best market melons, and we cannot recommend it too highly. Pkt., 5c; oz., 10c; 1/4 lb., 25c; lb. $80 \mathrm{c}$, postpaid.

\section{Continued}

Golden Honey-A golden fleshed melon, very tender and has a most delicious flavor. It is medium early, of large uniform size, oblong shape. This melon has no hard core or stringy sections. Pkt., 10c; oz., 20c; 1/4lb., 50c, postpaid.

Halberts Honey -A Texas melon which closely resembles Kleckley's Sweet, but darker color and more even and regular in shape. Cannot be shipped a great distance, as the rind is very brittle, but it is unsurpassed for home market and family use. It grows from 15 to 30 inches long, is dark green, slightly ridged, and blunt at the blossom end. The meat is as sweet as honey, melting, and leaves no trace of pulp. Always brings a higher price than any other melon on the market. Pkt., 10c; oz., 15c; 1/4 lb., 35 c; lb., 80c; 10 lbs., $\$ 7.00$, postpaid.

Florida Favorite - This is claimed to be a cross of Pierson and Rattlesnake. It is of oblong shape, large size; rind dark, with light green stripes; flesh light crimson, very crisp and deliciously sweet; seed light creamy white color; one of the earliest and best melons grown. Pkt. $5 c$; Oz.,10c; 1/4 lb., 25c; lb., 80c, postpaid.

Angels Kiss-The sweetest, tenderest melon in cultivation, with flesh of deepest indescribable crimson. Grows from medium to very large, oblong in shape; nearly white color, handsome and attractive. Vines are robust and strong growing. Pkt., 10c; oz., 15c; 1/4 lb., 30c; lb., 90c.

Tom Watson-The most popular shipping melon grown. The melons are large, long and dark green, like Kleckley's Sweet, but with a tougher rind, giving it excellent shipping qualities. The flesh is a rich red, solid, sweet, and luscious, and ripens up close to the rind. $\mathrm{Al}$ though a shipping melon, its fine qualities commend it to the private growers. Pkt., 5c; oz., 10c; $1 / 4$ lb., 25c; lb., 80c; $10 \mathrm{lb}$ lots, $\$ 6.50$, postpaid.

Georgia Rattlesnake -Melons are long in shape, of light green color, with dark stripes, and of uniformily large size and symmetrical shape; the rind is remarkably thin, though it stands shipping well. Pkt., 5c; oz., 10c; $1 / 4 \mathrm{lb}$. $25 \mathrm{c}$; lb., $80 \mathrm{c}$, postpaid.

NEW WONDER-It is all its name implies. Is well adapted to Southern conditions and for a shipping melon it can't be beat. The rind is tough and will withstand rough handling in transit, besides being a heavy cropper. It is a large, long, dark green melon faint stripes making a quick seller on the market. Flesh red, very crisp, solid and early. Pkt., 10c; oz., 15c; $1 / 4 \mathrm{lb}$., 40c; lb., $\$ 1.00$, postpaid. 


\section{Mustard}

Mustard is grown for greens and requires a loamy, rich soil, preferably a sandy loam. It is sown either broadcast or in drills; if it is sown broadcast, about 8 quarts of seed are required per acre; if in drills, 3 pounds per acre.

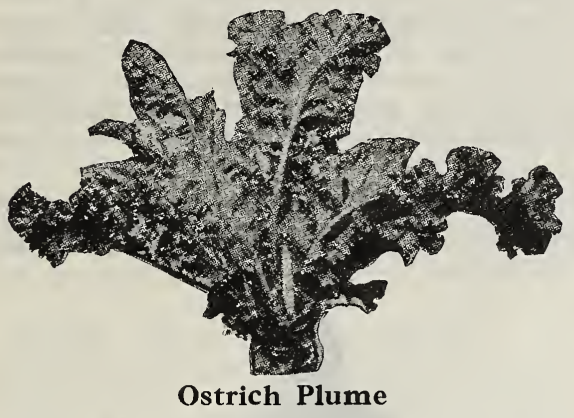

Ostrich Plume-Most beautiful variety and of very superior flavor. The leaves are beautifully ruffled and curled and curve outward like graceful ostrich plumes. They are ex- cellently adapted for garnishing. It originated in the South, and stands hot weatber exceedingly well. Plkt., 10c; oz., 15c; lb., 85c, postpaid.

Southern Giant Curled-A very, attractive curled sort, which is exceedingly popular in the South. Largely planted in the fall for greens. Pkt., 10c; oz., 15c; lb., 80c postpaid.

Elephant Ear-Desirable kind. Each plant produces extra-large leaves of good substance and of most appetizing pungency. It succeeds well also from spring sowings, but does not make so large during the warm summer as it does in the cooler fall or winter months. When they are grown in rich soil, the leaves attain sixteen to twenty inches in length; they are of light green color, with large white ribs or leaf stalks. Pkt., $10 \mathrm{c} ;$ oz., 15c; $1 / 4$ lb., 25c, lb., 90c.

\section{Okra, or Gumbo}

The young, tender seed pods of this plant are used for flavoring soups, stews, etc. They are regarded as a household necessity in the South, but are neither so well known nor so extensively used in the North. Seed should be sown when the weather has become settled, in drills 3 feet apart. Thin out the plants so they will stand from 1 to 2 feet apart in the rows. Gather the pods while they are young, as they become tough and woody when they grow older. One ounce will sow 100 feet of drill.

\section{Perkins' Mammoth Long-Podded} Okra-Pods shoot out from the stalk within 3 inches of the ground and the whole plant is covered with them to its extreme height. Pods are an intense green color, 9 to 10 inches long, very slim, and do not get hard. It is much sought by canners. Pkt., 5c; oz., $10 \mathrm{c} ; 1 / 4 \mathrm{lb}$., $20 \mathrm{c}$.

Dwarf Green-Bears pods ready for use ten days or two weeks earlier than the tall sorts. The plants are of dwarf, stocky growth, and are very prolific. Pkt., $5 \mathrm{c} ; \mathrm{oz} ., 10 \mathrm{c} ; 1 / 4 \mathrm{lb}$., 20c, postpaid.
White Velvet-Tall-growing sort, with attractive long white pods, which are round and of velvety smoothness. Pkt., 5c; oz., 10c; $1 / 4 \mathrm{lb} ., 20 \mathrm{c}$, postpaid.

We would suggest that, if convenient, you make up your orders as soon after the receipt of Catalogue as possible. It will help us to ship promptly and it will help you by giving you your goods when you want them. Placing your orders late makes delays unavoidable. But we have the facilities for handling a vast amount of business, and your order will receive our best attention, regardless of when it comes.

Gentlemen:

I am sending you photo of field of Artichokes I am growing for you, and you can conscientiously recommend the artichoke as the easiest to grow, the most prolific, and the heaviest yielding Hog feed I have ever grown. I cut and planted like Irish potatoes in March 1922. They stood the long dry summer and made 300 bushels to the acre. When grown for hog feed it is not necessary to dig or gather the crop, just turn the hogs on the patch after first heavy frost and they will root out as wanted. It is usually not necessary to plant the same patch the second year as the hogs will leave enough to grow the second crop. The land should be plowed flat and harrowed in March after hogs have been taken off for second crop. Artichokes, with plenty of good fresh water, salt and a little corn or Kafir to keep hogs teeth in good condition, will make more bacon and lard for less cost and work than any other crop the writer ever grew. Yours sincerely, W. F. Mills, August 13, 1924.

Box 508, Eufaula, Oklahoma

The photo not clear enough to make electro. See page 49 for Artichokes. 


\section{Perfection Brand Onion Seed}

One ounce will sow 100 feet of drill, 4 pounds will sow an acre. We pride ourselves on selling the very best onion seed that can be produced, and are now supplying some of the largest oniongrowers in the country. By sowing our seed, large onions can be produced direct from the seed.

CUL TURE-Sow in the early spring, in moist soil, as soon as the weather will permit, in rows 12 inches apart, and cover $1 / 2$-inch deep. If the onions grow too thick, thin to 1 inch apart, or only a very few onions will be the result. Manure highly (twenty loads to the acre being used by many market gardeners with profit), and if manure is not plentiful, some good phosphate, at the rate of 400 to 800 pounds per acre, will give good results. A top dressing of wood ashes, applied after the second weeding, is very beneficial.

SOIL-Onions need a rich loam, with a slight mixture of clay, manuring for two years previous.

MANURING-A liberal use of manure is essential and it should be of the best quality, well fermented, and shoveled over at least twice the previous summer to kill the weeds.

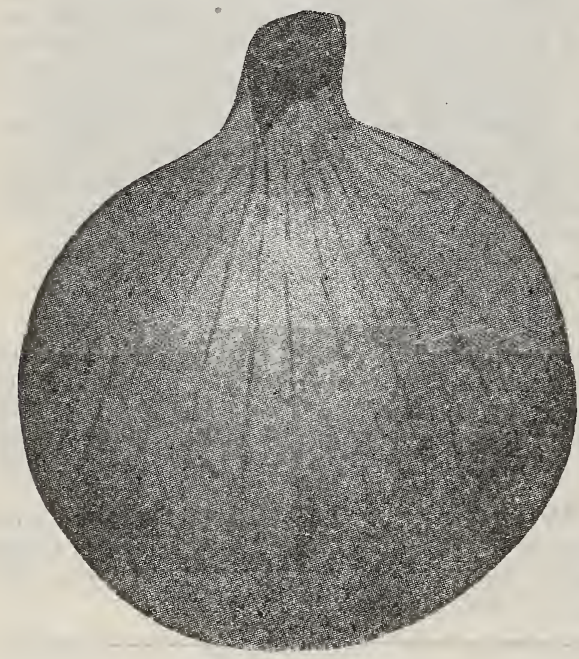

Prize Taker

Giant Yellow Prizetaker - The American-grown Giant Yellow Prizetaker is far the handsomest, most productive, most popular, and best of the yellow-skin onions. It grows in regular form, approaching the globe shape, has a very small neck, and ripens firm and hard. The flesh is pure white, firm and fine-grained, and mild in flavor. It is of immense size, measuring from 12 to 18 inches in circumference. Specimens have grown under special conditions weighing from 4 to $51 / 2$ pounds. It has proven to be of great value to farmers and gardeners, never failing to attract attention in the market, and is acknowledged to be the largest, finest-flavored, and most superior Yellow Globe onion under cultivation. Pkt., 10c; oz., 20c; 1/4 lb., 50c; lb., $\$ 1.50$.

Southport Large Red Globe--This handsome and most red-colored of all red sorts is becoming more popular every season.

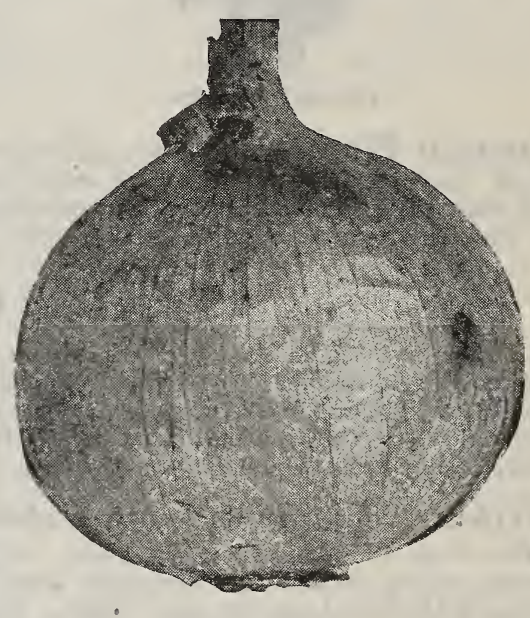

\section{Red Globe}

It is of a rich, glossy dark red, and makes a very attractive appearance. The bulbs are remarkably uniform in size and are splendid keepers. Pkt., 10c; oz., 20c;1/4 lb., 50c; lb., $\$ 1.50$.

Australian Brown - Of Australian origin, this splendid deep brown variety has proven a success where many other sorts have failed. It is adapted to a great variety of soils, and is not easily affected by climatic conditions. The bulbs somewhat resemble the Danvers in size. It is extremely early maturing six weeks before the Red Wethersfield. The flesh is firm and of mild flavor, and the ripe bulbs will keep in good condition for nearly a year after they have been harvested. Pkt., 10c; oz., 15c; 1/4 lb., 25c; lb., 90c.

Crystal White Wax Bermudas-.Genuine Teneriffe grown. A beautiful crystal white with the decided waxy appearance. It is the earliest of the Bermuda varieties, and makes large flat onions; so mild and sweet that they can be eaten like an apple. Crop very short. Ask for prices. 


\section{ONIONS-Continued}

Yellow Bermuda - It is a standard variety and grown in Texas in large quantities. Makes onions 3 to 4 inches in diameter; flattened in shape, but very thick, very mild and sweet. Pkt., 10c; oz., 50c; 1/4 lb., 1.50; lb. $\$ 5.00$, postpaid.

White Globe-The bulbs grow to good size, sometimes measuring 5 to 7 inches across and weighing from 2 to 3 pounds. They are flat shaped, but thick through, very handsome and of extremely mild flavor; of quick growth and early maturing. Pkt., 10c; oz., 20c; 1/4 lb., 60 c; lb., $\$ 2.00$, postpaid.

Large Red Wethersfield - The most widely cultivated of the red varieties; the standard winter onion in many Northern States. The bulbs are well flattened, thick through and grow to a good size. The skin is a rich glossy color, while the flesh is white, tinged with red; a most excellent keeper. Pkt., 10c; oz., 20c; $1 / 4$ lb., 50c; lb., $\$ 1.40$, postpaid.

White Portugal or Silverskin-.-An early-ripening, good sized sort, of clear, silvery-white color, of very mild flavor, and extensively grown for pickling. Pkt., 10c; oz., $20 \mathrm{c} ; 1 / 4 \mathrm{lb}$., $50 \mathrm{c}$, postpaid.

Early White Queen-The earliestripening onion in cultivation, producing handsome silver-skinned bulbs of beautiful appearance early in the summer. Largely used for small pickles, as it is of fine mild flavor. Pkt., $10 \mathrm{c} ;$ oz., 25c; $1 / 4$ lb., 75c, postpaid.

Yellow Globe Danvers - Handsome, nearly globe-shaped bulbs of pale yellow color; crisp, pure white flesh of mild flavor. Pkt., 10c; oz., 20c; $1 / 4$ lb. 55c; lb.. \$1.40, postpaid.

\section{PARSLEY}

The leaves are used for garnishing meats, fish and other dishes, and as a flavoring for soups and stews. Grows in any garden soil. Seed is of slow germination and should be planted early in spring in rows 10 inches apart. A few plants will supply a family

Moss Curled-Leaves are very ornamental, curled and crimped; also excellent for seasoning. Pkt., 10c; oz., 15c; 1/4 lb., 25c.

\section{- PARSNIPS}

This is a hardy vegetable, used for food for both humans and stock. It is grown similar. to the carrot, and requires a rich, loamy soil.
Improved Hollow Crown - A great cropper and considered the best for cultivation. The ronts are long, smooth, tender, and very sugary. Pkt., 10c; oz., 25c; 1/4 lb., 65c.

\section{ONION SETS}

Bermuda Onion Plants-Yellow, 35c per 100, postpaid. Ask for special prices in quantities.

Dark Red-Lb., 25c, postpaid; by freight or express, not prepaid, lb 20 c.

Yellow -Lb., 25c, postpaid; by freight or express, not prepaid, lb., $20 \mathrm{c}$.

White Silverskin -Lb., 30c; postpaid by freight or express, not prepaid, lb., 25c;

White Multiplier Sets - They are of a pure silvery-white color, enormously productive, frequently producing as many as twenty shoots for bunching from one bulb planted; of excellent quality and size for bunching. Lb., 40c; postpaid; by freight or express, $30 \mathrm{c}$ per $\mathrm{lb}$.

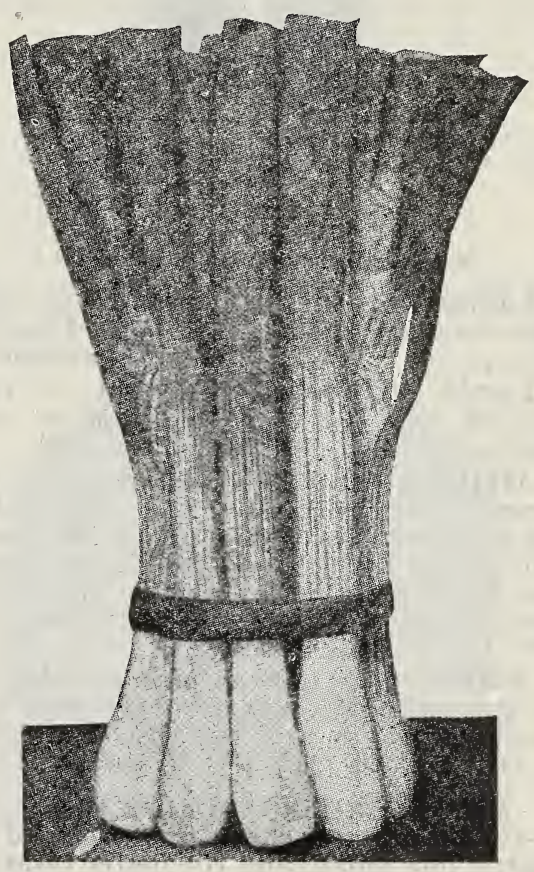




\section{Perfection Brand Garden Peas}

Peas require a good, well-worked garden soil. Well-rotted manure and wood ashes are the most suitable fertilizers. Plant as early in the spring as the ground can be worked, for the dwarf varieties, in rows about 8 to 10 inches apart and $11 / 2$ inches deep. The large varieties are sown in rows about 2 to 3 feet apart. One quart of seed is required for 100 feet of drill and $1 \frac{1}{2}$ bushels to the acre.

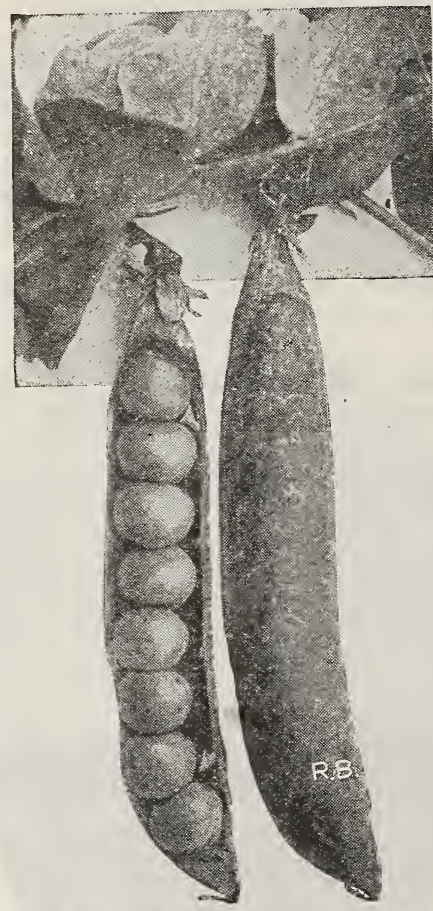

Gradus, or Prosperity

(Cut is reduced one-half size of pod)

Champion of England-For main crop or summer use, this is the standard variety. Very prolific. Pkt., 10c; lb., 30c, postpaid.

Large White Marrowfat-A very late sort that bears large quantities of well filled pods. Pkt., 10c; lb., 30c, postpaid.

Melting Sugar-(Edible pod.) In this variety, which is the best of its class, the entire pod is cooked the same way as string beans. The pods are large, flat, very brittle and tender and fine-flavored when cooked. The vines attain a height of 4 feet and are very attractive. Pkt., 10c; lb.,40c, postpaid.

Alaska - We have an enormous demand for this variety, and our sales have more than doubled within the past two years. A number of our customers plant 5 to 10 bushels of this pea. The earliest smooth pea in existence. The pods are medium in size, well filled and mature practically all at one time. Our strain is extra selected. Pkt. 10c; lb. 35c,-postpaid; by freight or express, lb., 30c; 10 lbs., $\$ 2.50$.

First and Best-(Extra Early.) The vines average 18 to 24 inches in height, setting a good number of choice pods filled with choice peas of excellent flavor. Pkt., 10c; lb., 35c, postpaid; by freight or express, lb., 30c; $10 \mathrm{lbs}$., $\$ 2.50$.

Gradus, or Prosperity-The earliest large podded pea in cultivation; the immense pods are as large as those of the Telephone, uniform and well shaped, filled with large, handsome peas. The vines have heavy stems, with large, dark green leaves, growing 3 feet in height. Pkt., 10c; lb., 40c, postpaid.

American Wonder-The plants grow only 10 inches high and produce an abundance of medium-size pods, which are filled with large, sweet peas of luscious quality. Pkt., $10 \mathrm{c} ; 1 \mathrm{~b} ., 35 \mathrm{c}$, postpaid.

Nott's Excelsior -Of compact growth with many handsome, good-sized pods, which are closely packed with large peas of unusually sweet flavor. Matures almost as early as the American Wonder and the pods are larger. Pkt., 10c; lb., 35c, postpaid.

Dwarf Telephone - Dwarf Telephone is the famous old Telephone without its long vines. It is of healthy, stocky growth and enormously productive. The pods frequently measure 5 inches in length, are broad, straight and remarkably well filled, often containing 9 or 10 peas. Pod is dark green, thick and plump. Vines grow about 2 feet high. Pkt., $10 \mathrm{c} ; \mathrm{lb} ., 35 \mathrm{c}$, postpaid. By freight or express, lb., 30 c; 10 lbs., $\$ 2.50$.

Telephone -A large sort, with tallgrowing vines. The pods are very large, with large peas of delicious flavor. Pkt., 10c; lb., $35 \mathrm{c}$, postpaid.

SMALL ORDERS-We like them. Thousands of seed-planters think that a 10 to 50-cent seed order is too small to send; it is not. We are glad to have your orders, no matter how small, and the better results in your garden make it worth while for you to send to us. Remember, there is no order, small or large, that is not welcome. 


\section{PEPPER}

The young plants are raised like tomatoes or egg plant. They should be set out after all danger of frost is over and the ground is warm. Set the plants about 2 feet apart in roms 3 feet wide. One ounce of seed will produce about 1,500 plants.

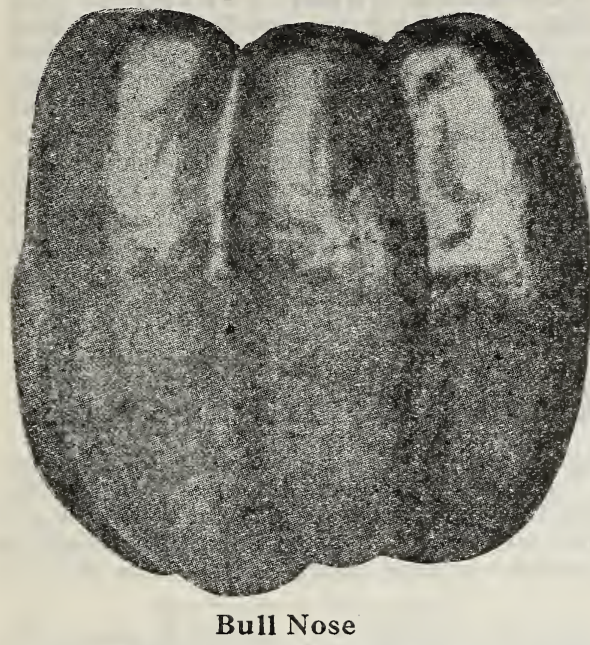

New Pimento Peppers-This is a new pepper that is largely grown in California and is fast becoming popular in the South, where it will eventually be grown largely for canning purposes. It is fine for the home garden, both green and ripe. It is so smooth and uniform in shape that the skin can be easily slipped off after burning over a hot fire a few seconds or by boiling a few minutes in hot water. It can also be pared like an apple by using a sharp knife. The green peppers can be pared best in this way. In quality it is very sweet and delicious and entirely free from pungency; in color, when ripe, it is a beautiful green. It is very productive, yielding heavy crops until cut off by frosts. It is much sought and grown by canners for pickles and pulp. Plant an ounce or so of this variety this spring. Pkt., 10c; oz., 40c; 2 ozs., 75c.

Ruby Giant-A beautiful pepper, being a cross between the Chinese Giant and Ruby King. It combines the larger size and productiveness of the Chinese Giant and the attractive shape and color of the Ruby King. The flesh is mild and sweet, and can be sliced and served with tomatoes. The fruits when ripe are a bright, glossy, ruby red color. Pkt., 10c; oz., $40 \mathrm{c} ; 1 / 4 \mathrm{lb}$., $\$ 1.50$.

Chinese Giant-This is the largest mild red pepper in existence. The strong, stocky plants are of bushy, perfect growth. The peppers are of enormous size, specimens weighing 18 ounces are found quite frequently. They are of square block form; the flesh is very thick and extremely mild. Pkt., 10c; oz., 50c; $1 / 4$ lb., $\$ 1.75$, postpaid.

\section{Large Bell, or Improved Bull-} nose-A large early sort, with thick mild flesh. Pkt. 10c; oz. 40c; $1 / 4$ lb. $\$ 1.50$, post paid.

Ruby King-A very prolific popular sort bearing splendid crops of splendid large thick peppers; of good quality for mangoes. Pkt., $10 \mathrm{c} ;$ oz., $50 \mathrm{c} ; 1 / 4 \mathrm{lb}$., $\$ 1.50$,postpaid.

Large Red Cayenne-Bright red fruits 3 to 4 inches long, very hot. Pkt., 5c; oz., 40c; $1 / 4$ lb., $\$ 1.50$, postpaid.

\section{PUMPKINS}

Avoid planting pumpkins in the garden, as they will mix with cucumbers, melons, and other vines. Usually they are planted in the corn-field, dropping three or four seeds every fourth hill, but they do better planted by themselves. Plant about 8 or 10 feet apart each way. Put some wellrotted manure beneath each hill thoroughly mixing it with the soil.

KING OF MAMMOTH PUMPKIN-Also called Jumbo, Mammoth Prize, or Mammoth Potiron. A really enormous variety and a prize winner everywhere. On good ground and under high cultivation this pumpkin frequently grows to an immense size. Not withstanding the enormous size " $t$ is one of the best pie pumpkins, having very thick sweet flesh which cooks quite dry and tender. To grow pumpkins of the largest size it is advisable to leave only one plant to a hill, leaving only one fruit to a plant, and give pumpkin plenty of room. Pkt., 10c; oz., $15 \mathrm{c} ; 1 / 4$ lb., $40 \mathrm{c} ; 1 \mathrm{lb}$., $\$ 1.50$, postpaid.

LARGE SWEET CHEESE, OR KENTUCKY FIELD-A popular and very productive variety. The ripe fruits are flat, of a rich creamy yellow color, and measure about 2 feet in diameter. Pkt., $5 \mathrm{c} ;$ oz., $10 \mathrm{c} ; 1 / 4 \mathrm{lb}$. $30 \mathrm{c}$; lb.; 50c, postpaid. By freight or express, lb., $45 \mathrm{c} ; 10$ lbs., $\$ 4.00$.

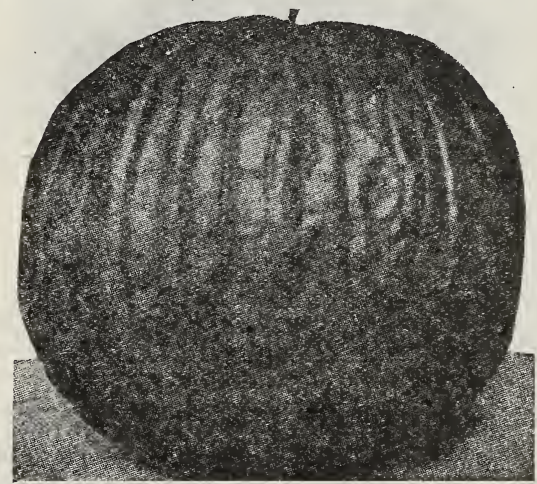

Kentucky Field 


\section{Page 26 PERFECTION BRAND SEEDS}

\section{Pumpkin--Continued}

IMPROVED GREEN-STRIPED CUSHAW -A crook-necked variety, with green and white striped skin. The flesh is of a rich yellow color solid fine-grained very thick and sweet. Pkt. $10 \mathrm{c} ;$ oz. $15 \mathrm{c} ; 1 / 4 \mathrm{lb} .40 \mathrm{c} ; \mathrm{lb} . \$ 1.25$, postpaid.

SMALL SUGAR - Hand some and prolific, of small size, averaging about 10 inches in diameter; skin is a deep rich orange-yellow, fine-grained. sweet, dry, and an excellent keeper; a nice table variety. Pkt., 10c; oz., 15c; 1/4 lb., 30c; lb., 90c, postpaid.
TENNESSEE SWEET POTATO-A good variety for making pies and for other cooking purposes. It is of medium size, and of a white creamy color. with excellent flavor. This is a good keeper. Pkt. 10c; oz., 15c; 1/4 lb., 35c. Postpaid.

JAPANESE PIE-Similar in shape and size to the well-known Cushaw, but the skin is deep green, with dark stripes running to a rich golden yellow. Fruits mature early; the large neck is solidly meaty, and the seeds are marked with curious indentations, resembling the characters of the Chinese alphabet; flesh deep vellow, of fine quality. Pkt., 10c; oz., 15c; $1 / 4 \mathrm{jb}, 35 \mathrm{c}$.

\section{Perfection Brand Radish Seed}

Our stock of radish seed is grown for us in Michigan. Great care is used in selecting this seed, and the quality is of the best. A trial will convince. Radishes are among the most valued of the early vegetables and a liberal supply should be grown in the home garden throughout the spring and summer. They develop best and quickest in light rich sandy soil. Well-rotted manure should be used and constant cultivation is necessary to insure radishes of good quality. One ounce will sow 75 feet of drill; 8 to 10 pounds per acre.

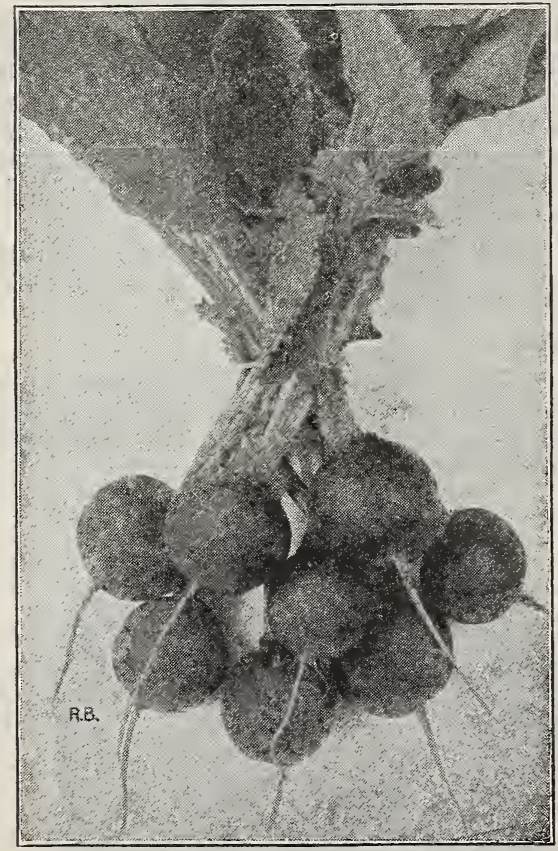

EARLY SGARLET GLOBE-This is a splendid variety for hot-bed or green-house culture. We consider it the best of the round scarlet forcing sorts. The radishes mature quickly, producing small growths of tops, and are solid and crisp; very uniform in shape. The color is a handsome bright scarlet. Pkt., 10c; oz $15 \mathrm{c} ; 1 / 4$ lb., 30c; lb., 80c; 5 lbs., $\$ 3,25$.

CRIMSON GIANT-An entirely new variety and differs radically from all others, inasmuch as the roots attain more than double the size of the other forcing varieties without getting pithy or hollow. It is very early, notwithstanding its size. Color, crimson; meat, pure white and of the best quality. The seed should be sown very thinly to permit the development of the roots. Pkt., 10c; oz., 15c; $1 / 4$ lb., 35c; lb., 90c, postpaid.

EARLY FRENCH BREAKFAST-A beautiful olive-shaped sort of bright scarlet color, with well-defined white tip; a rapid grower; very mild and tender. Pkt., 10c; oz., 15c; $1 / 4 \mathrm{lb}$., 35c; lb., 90c, postpaid.

LONG SCARLET SHORT TOP-Roots grow 5 or 6 inches long and are very attractive, crisp. Pkt. 10c, oz; $15 \mathrm{c}, 1 / 4 \mathrm{lb}$.. $35 \mathrm{c} ; \mathrm{lb}$., $90 \mathrm{c}$, postpaid. By freight or express, lb., 80c; 5 lbs., $\$ 3.50$.

CINCINNATI MARKET-A fine extra early variety, with a long, smooth root and small top. The color is a bright red, the flesh tender and delicious, even when full grown. It is undoubtedly the best long radish for shipping to distant markets. Pkt.,10c; oz.,15c; 1/4 lb., 35c;lb.,90c.

WHITE-TIPPED EARLY SCARLET TURNIP-For outdoor sowing this is the most important sort in the market, thousands of pourds being annually used. Our stock of this is the best. Handsome bright scarlet color, with white tip. Its fine appearance attracts customers and its quality always pleases. Pkt., 10c; oz., 15c; $1 / 4$ lb., 30c; lb., 75c, postpaid. By freight or express, lb. 70c; 5 lbs., $\$ 3.25$. 


\section{Radishes-Continued}

CHARTIER - In shape it resembles the Long Scarlet, but it grows to much larger size, and keeps in good condition longer than most other varieties. Pkt., 10c; oz., 15c; 1/4 lb., 30c; lb., $\$ 1.00$. postpaid.

ICICLE-The finest eating white radish; has long, slender, pure white roots, which remain fresh and crisp until they grow to a large size; tops are quite short, making it early, and allowing close planting. Pkt., 10c; oz., 15c; $1 / 4$ lb., 30c; lb., 80c, postpaid.

LONG WHITE VIENNA, OR LADY FINGER -An excellent variety of the summer radishes; long, pure white, and of mild flavor. Pkt., 10c; oz., $15 \mathrm{c} ; 1 / 4 \mathrm{lb}$, 30c; lb., $95 \mathrm{c}$, postpaid.

WHITE STRASBURG-This variety is one of the most popular summer kinds. Both flesh and skin are pure white; remains tender longer than any other variety. Pkt., 10c; oz., 15c;1/4 lb., 30c; lb. 90c. postpaid.

\section{WINTER VARIETIES}

The merits of Winter Radishes are little appreciated, probably because they are seldom grown, and few people have knowledge of their worth. These grow to large size and keep well for autumn, and winter use. Sow the seed from the middle of July until the middle of September. Include some of these with your order.

CALIFORNIA MAMMOTH WHITE Roots white and when fully matured 9 to 12 inches long by 2 to 4 inches in diameter just below the shoulder, tapering regularly to the tip. Flesh firm, crisp, well flavored, and will keep well through the winter. Pkt., 10c; oz., 15c; $1 / 4 \mathrm{lb}$., 30c., lb., 90c, postpaid.

CHINA ROSE WINTER-Of bright deep rose color; flesh firm and excellent for keeping. Plkt., 10c; oz., 15c; 1/4 lb., 30c; lb., 90c, postpaid.

LONG BLACK SPANISH-With black skin and white flesh; will keep until spring. Pkt., 10c; oz., 15c; $1 / 4$ lb., 30c; lb., 90c, postpaid.

ROUND BLACK SPANISH-The black, white-fleshed roots are practically round, about three inches in diameter. This variety is exceptionally good for storing for use all winter long. Pkt., 5c; oz., 15c; $1 / 4$ lb., 30c; lb., 90c, postpaid.

\section{Rhubarb, or Pie Plant}

It is grown either from seed or by propagation of the roots. The soil for rhubarb should be made extremely rich, using manure every other season. The seed should be sown early in the

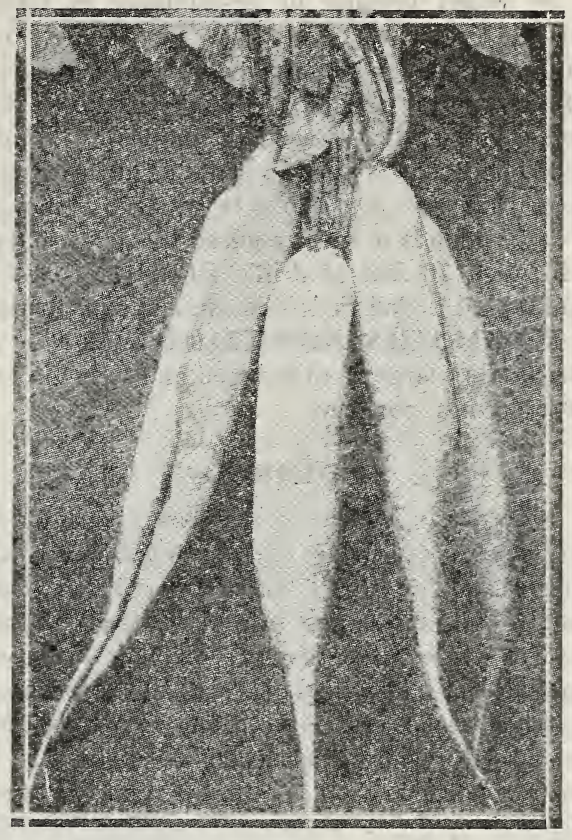

Icicle

spring in rows 12 inches apart and 1 inch deep. Thin the plants out to stand 5 inches apart and cultivate throughout the summer. In this section of the Southwest the plants get large enough to use in the fall from seed sown the previous spring, if the season has been favorable. The roots should be planted 3 feet apart in the row and with the crown about 4 inches under the soil. One ounce of seed will sow 100 feet of drill.

VICTORIA GIANT-This is a very large and late variety; with round stalks of great length and thickness; produces a succession of stalks the whole season; held high in the esteem of market gardeners. Pkt., 10c; oz., 20c; 1/4 lb., $50 \mathrm{c}$.

\section{Rhubarb Roots}

The city farmer who desires to raise Rhubarb and finds he cannot get a start easily from the Rhubarb Seed should plant the roots and grow from them. Our Rhubarb Roots are selected with special attention to their strength and hardiness. We will be in position to supply Rhubarb Roots during the month of March. We advise purchasers to place their orders with us before that time. Orders filed early will be certain of being filled. Those which come later, we can only promise to do our best to serve. See page 33 . 


\section{Salsify, or Oyster Plant}

So called because of resemblance in flavor to the oyster when cooked. Tap loot is long and resembles a parsnip and one-half the size of an ordinary parsnip. Requires a deep rich soil and the whole season to mature in. Plant seed about 1 inch deep in drills 12 inches apart; later thin out young plants to 4 or 5 inches. 8 or 10 pounds of seed required to acre; 1 ounce will plant 70 feet of drill. Roots may be dug and stored in fall or left in ground over winter.

MAMMOTH SANDWICH ISLAND-

Grows very large; well flavored and mild. Pkt. 10c; oz. 20c postpaid.

\section{Spinach}

A spring plant used for greens. Very hardy and most in demand in early spring and late fall. Leaves are large, rich and tender. Very easy culture and grows best in cool weather. Rapid growth is desirable that leaves may be strong and tender. Soil should be rich and given good coltivation. If seed is sown out of doors they should be planted as soon as ground is in good condition. For fall use seed may be sown the middle of September. One ounce will sow 100 feet of drill.

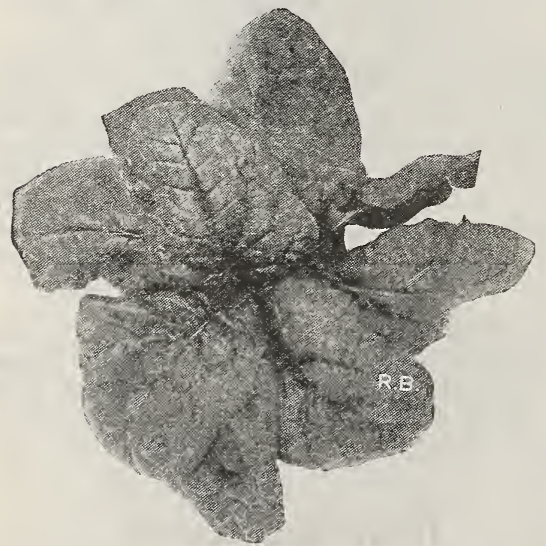

BLOOMSDALE-This is the most popular variety. The fleshy leaves are of true Savoy appearance; very hardy. Pkt. 5c; oz. 10c; lb. 50c postpaid. By freight or express $1 b$. $40 \mathrm{c} ; 10$ lbs. $\$ 3.00$.

KING OF DENMARK-The best long season Spinach remaining two weeks longer than others before lofting to seed. Plant vigorous and spreading; leaves large rounded crumpled and blistered; deep green in color. Pkt. 10c; oz. $15 \mathrm{c} ; 1 / 4 \mathrm{lb}$. 30c; lb $90 \mathrm{c}$ postpaid.
NEW ZEALAND-This is entirely different from any other variety, as it is available during the hottest months of the year sending out fresh growth after being cut cortinuously up until frost. Stems and leaves are thick fleshy tender and succulent. Very productive.Should be in every garden. Pkt. 10c; oz. 15c; $1 / 4$ lb. 35c postpaid.

\section{Squash}

Squashes require a warm fertile soil of sandy nature for best growth. Summer squashes grow mostly in compact bush form; bills for these should be about 4 feet apart; for long trailing fall and winter varieties hills should be 8 to 12 feet apart each way. If ground is not very rich two or three shovel full of well-rotted manure should be worked into each hill. Put 8 to 10 seeds in each hill about 1 inch deep. When danger from bugs is over thin to three to four of the strongest plants.

WHITE BUSH OR PATTY PAN-The best early variety. The plants are of true bush form and produce fruits very early in the season. Largely grown in the South for shipment to Northern markets. Pkt. 5c; oz. $15 \mathrm{c}$; $1 / 4 \mathrm{lb} .40 \mathrm{c}$ postpaid.

MAMMOTH WHITE BUSH-Not quite as early as the preceeding but is very much larger. It makes a strong bushy growth and bears fruit frequently 12 to 14 inches in diameter. The squashes are thick with scalloped edges. Pkt. 10c; oz. 15c; $1 / 4 \mathrm{lb} 40 \mathrm{c}$.

YELLOW SUMMER CROOKNEGK-The plants are very productive and early-bearing; skin of fruits very thickly warted and of orangeyellow color. Pkt., 10c; oz., 15c; $1 / 4$ lb., $40 \mathrm{c}$.

MAMMOTH GOLDEN BUSH-Like the Mammoth White Bush. However, the fruits are a little larger and have a pale yellow skin, with creamy flesh. Pkt., 5c; oz., 15c; $1 / 4$ lb., 40c.

HUBBARD - The most popular table variety. Fruits are of oblong shape, with attractive olive skin which is warted. Pkt. 10c;0z. 15c; $1 / 4 \mathrm{lb} .45 \mathrm{c}$.

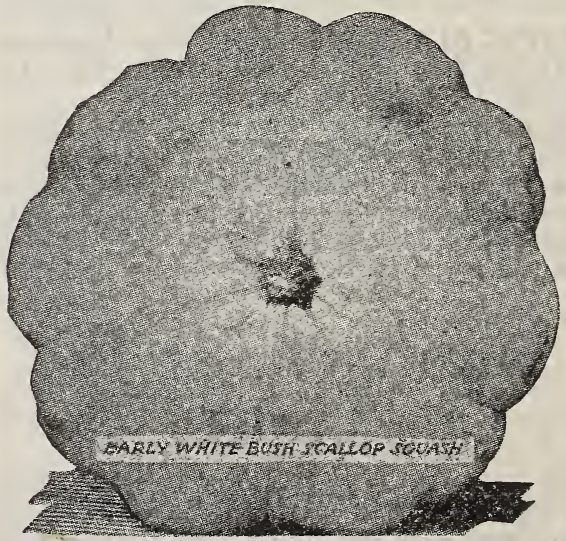

Slugishot will destroy squash bugs. 


\section{Selected Irish Potatoes-Northern Grown}

Culture-To secure the best results in growing potatoes it is necessary to plant as early as the ground can be made ready. Use a rich soil and plant in rows 3 feet apart and the sets a foot apart in the rows. A complete potato fertilizer sown into the rows will aid in harvesting the crop at an earlier date and usually shows an increased yield. Some growers who wish to harvest a very early crop sprout the potatoes before planting by cutting the potatoes into pieces of desirable size and placing them in a warm ligbt room for three or four weeks before planting in the open ground. If the weather is favorable, the shoots will start out strong and vigorous, and as soon as the plants have sent out roots they grow more rapidly than freshly-cut potatoes.

On account of market fluctuations we are unable to name exact prices. We will be pleased to have you write during the month of January or later and we will then quote prices for prompt or future shipment.

Diseases and failures in obtaining a profitable crop of potatoes are attributable chiefly to carelessness in planting poor unselected seed. The average farmer usually pays less attention to the quality of his seed potatoes than any other seed he plants. He seems to think that any old kind of potato he happens to have on hand will do for seed then wonders why his crop was a failure or the potatoes so poor and scrubby. Yet they will continue to plant this stock year after year rather than pay a fair price for some good carefully selected seed stock that would produce more and better crop.

Our Certified Seed Potatoes were grown in the Red River Valley of Minnesota and are strictly ancy stock. Should not be compared to average stock as offered by grocers and commission houses.

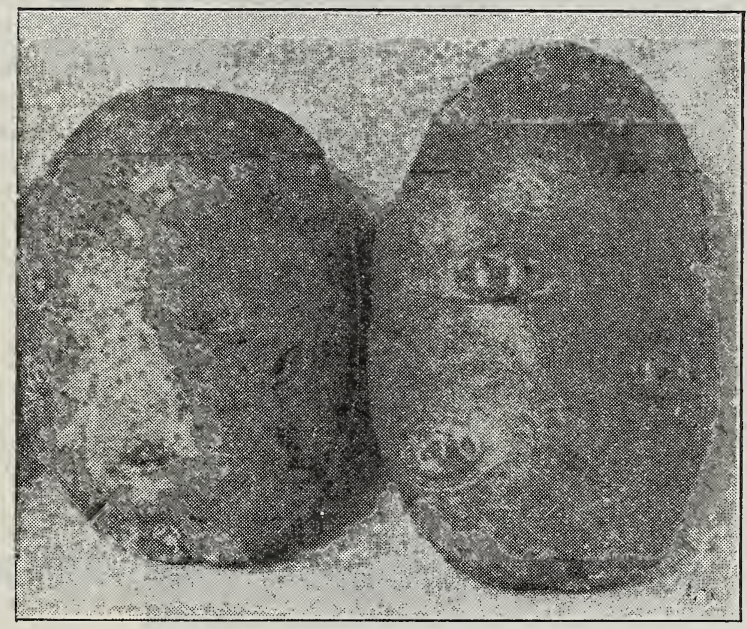

TRIUMPH-Very early. Tubers are of medium size. round and uniform in shape with but few small ones; eyes slightly deprsssed; color a beautiful light red. Its beauty productiveness and fine quality make it one of the best extra early market varieties. especially for the South.

EARLY OHIO-Our stock of this variety is grown in the Red River Valley of the North. The best variety for the Western States. and its superior has not been introduced to date. It is fit for table use before fully ripe. and can be shipped earlier than any_other white potato.

IRISH COBBLER-A variety which in recent years has attained popularity. In many soils is as early or within a few days as early as Early Ohio. and the yield is superior. Added to this last the potato is chunky, white in color and of large medium size, making it the most attractive variety by far on the early market. 


\section{Tomatoes}

Everyone likes a good Tomato and every garden should have at least a dozen hills of Tomatoes. They may take a little more work than some other vegetables, but the occasional hoeing needed is well repaid by the constant supply of delicious fresh fruit all summer long. When the first frost comes in the fall, there are usually a number of green tomatoes left on the vines, these make an excellent pickle which will be relished the whole winter. If you are not familiar with how to put up green tomatoes, our service department will be glad to tell you about it. We pay special attention to raising tomato plants for the home garden.

Culture: Sow seed in a box or hotbed early, ond transplant at least once to get good strong root growth. When danger of frost is over, set in the open ground 3 to 5 fet apart each way and cultivate thoroughly. Fruits may be had several days earlier by transplanting into small pots and then setting out the entire contents when the ground is dry and warm. One ounce of seed will produce from 2000 to 3000 plants. It greatly increases the quality and earliness of the fruit if the vines are tied to trellis or stakes to keeps the fruit off the ground. If this is not convenient it will help considerably, particularly on heavy soils to throw a little straw or litter under each vine.

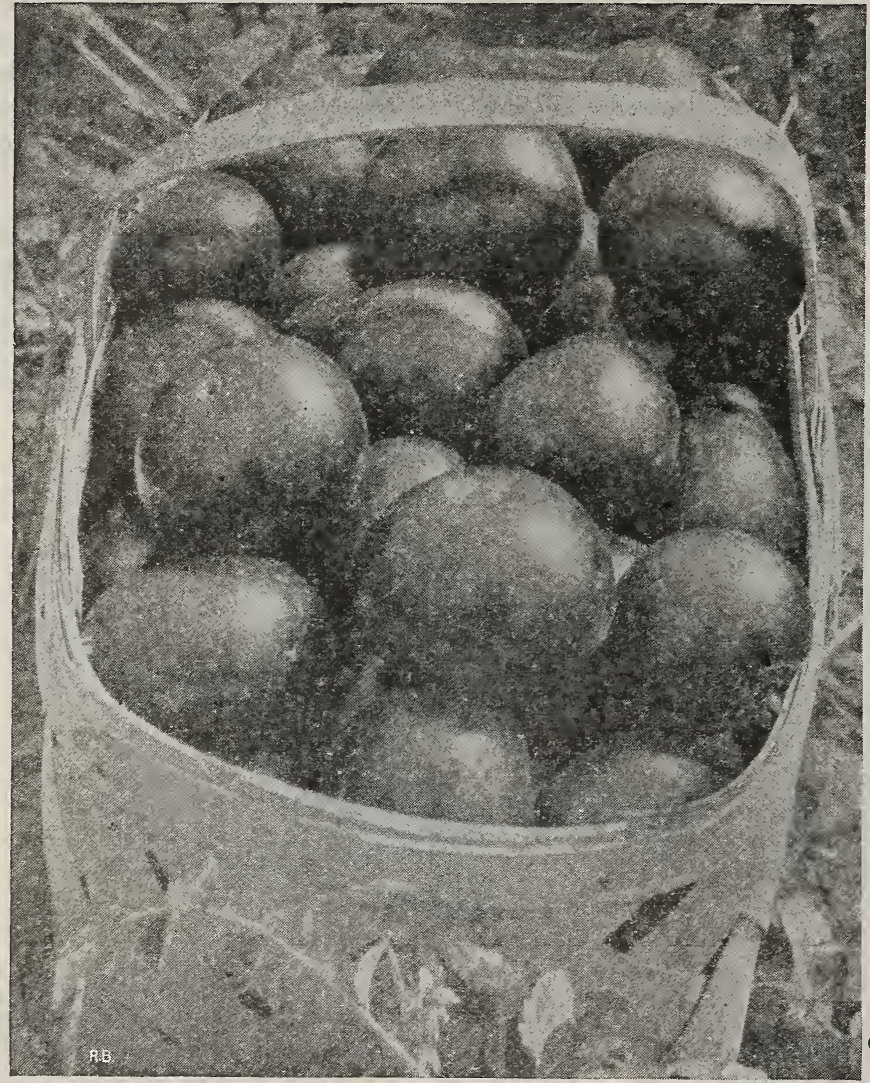

John Baer
SPARKS' EARLIANAOriginated a few years ago by one of the most successful trucksters of New Jersey, it has proven to be the best and brightest red tomato. Coming into the market before any other sort, it commands top prices. The fruits are solid, uniform in shape, and of a rich bright-red color. The tomatoes are produced in clusters, and generally can all be gathered in about three weeks from the time the first fruits ripen. They are of good flavor and contain few seeds. Pkt., 10c; oz., 25c; $1 / 4$ lb., 70c; lb., $\$ 2.50$, postpaid.

JUNE PINK-In habit and growth it is similar to Earliana. The plant is neat and compact, branching freely, with fruits ranging in clusters of 6 to 10. The fruits are of medium size and uniform, smooth, and of attractive shape, without cracks or any green core. This is an excellent shipping tomato as the skin is very tough. It will continue to bear fruit until frost. Pkt. 10c; oz. 40c $1 / 4$ lb. $\$ 1.50 ; \mathrm{lb}$. $\$ 4.50$, postpaid.

GHALK'S EARLY JEWEL-One of the best early tomatoes yet introduced. The Vines are vigorous and very productive. Fruits deep scarlet red, nearly round or somewhat flattened, smooth of large size and most excellent quality. They ripen very early, and the pickings continue through a long season. Unsurpassed for a bome garden. Plkt. $10 \mathrm{c}$; oz. 30c; $1 / 4 \mathrm{lb}$. 90c; lb. $\$ 3.25$, postpaid. 


\section{Tomatoes-Continued}

JOHN BAER - Perfection Strain. Earliest of the earliest. This seed is grown for us in the North by an experienced man that grows no other variety of tomato. This variety produces the most perfect High Crown Tomato ever grown. Entirely free from core, is an enormous yielder. Ripens right up to the stem and has no blight, no cracked, no wrinkled, no one-sided scarred fruits. When dead ripe John Baer will not burst. Has a mild, delicious sweet flavor, is almost seedless, and brilliant bright red color. Our Perfection strain of John Baer is the most perfect shipping tomato on the market. Pkt., 10c; $1 / 4$ oz., 35c; oz., $60 \mathrm{c} ; 1 / 4 \mathrm{lb}$. $\$ 1.75$ postpaid.

GOLDEN QUEEN OR GOLDEN TROPHY - It is large in size. round firm smooth, and yellow in color, with a reddish touch at the blossom end. The fruits are of splendid quality, not exceeded by any other in cultivation. Pkt., 10c; oz., 40c; 1/4 lb., $\$ 1.00$, postpaid.

MATCHLESS - A standard, largefruited main crop sort; bright red color; uniform in shape, and of superior flavor. Pkt.,10c; oz., 25c; 1/4 lb., 80c; lb.. \$2.50.

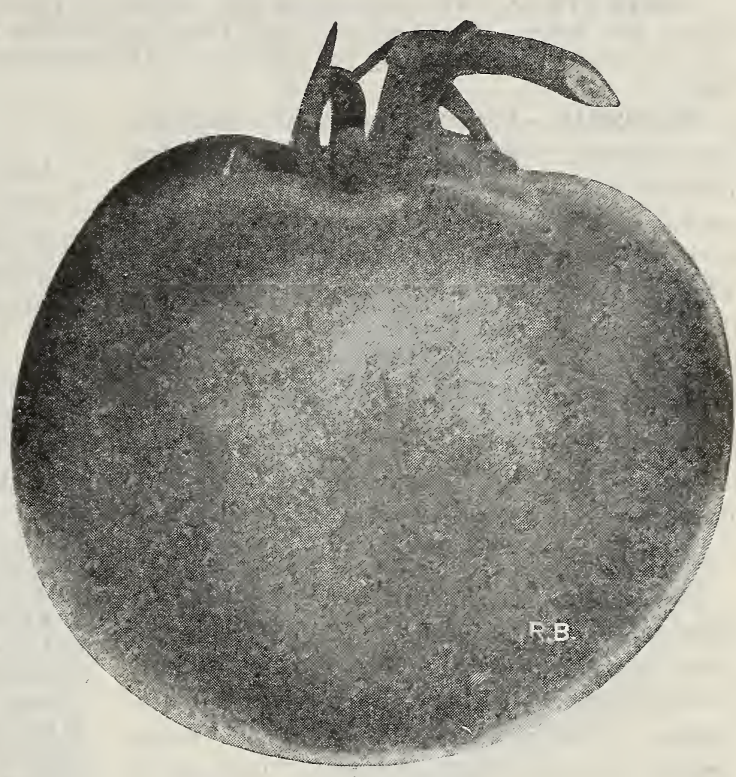

Ponderosa

BEAUTY-Large and glossy crimson fruits, smooth and never cracking: holds it size until late in the season one of the best. Pkt., 10c; oz., $30 \mathrm{c} ; 1 / 4 \mathrm{lb}$., $90 \mathrm{c}$; lb., $\$ 2.75$, postpaid.

ACME - The standard bright, pink tomato; very popular and of the best for family use. The fruits are round, very solid, uniform in size, and ripen early. Pkt., 10c; oz.. 30c; $1 / 4$ lb., 90c; lb., \$2.75 postpaid.

PONDEROSA-Largest fruited tomato in cultivation, single fruits often weighing from 2 to 4 pounds and measuring 18 inches in circumference. It is solid and meaty to the heart and has small seed cavities. For this reasor: selected seed of this variety will always be scarce. Fine for slicing and of excellent flavor. Pkt., 10c; oz., 40c; $1 / 4$ lb., $\$ 1.25$ $\$ 4.50$.

NEW STONE-Immensely popular with canners, Southern shippers, and market gardeners. It is a remarkable yielder, very firm, and of a handsome bright red color. We believe this is the most widely known variety of today. It is of excellent shape with very smooth skin, never cracking, and free from green core. Ripe fruits will keep in good marketable condition nearly two weeks after being picked. Plkt., 10c; oz., 20c; $1 / 4$ lb., 50c; lb., $\$ 1.75$ postpaid.

NEW RED ROCK TOMATO-This is one of the finest large red tomatoes ever introduced. It ranks among the later varieties, requiring about 110 days from seed-sowing to ripe fruit. It is very solid and free from excess water; smooth, and of a very fine red color. . Pkt., 10c; oz., 25c; $1 / 4$ lb., 75c; lb., \$2.50. Postpaid.

DWARF STONE-The fruit is a bright glossy red in color and is produced in clusters of four or five tomatoes. The shape of the fruit is round and ripens clear to the stem, perfectly smooth; has very few seeds, being thick and firm, of excellent flavor. It is of good size and very early. Set plants two feet apart in three foot rows. Pkt. 10c; oz. 40c; $1 / 4$ lb. $\$ 1.25$. Postpaid.

RED PEAR_Used whole for salads and preserving. Pkt. 10c; $1 / 2$ oz. 30c; oz. 50c.

YELLOW PEAR-Used whole for salads and preserving. Pkt. 10c; $1 / 2$ oz. $30 \mathrm{c}$; oz. 50c.

YELLOW CHERRY-Used whole for salads and preserving. Pkt. $10 \mathrm{c} ; 1 / 2$ oz. 30c; oz. $50 \mathrm{c}$.

RED CHERRY-Used whole for salads and preserving. Pkt. 10c; $1 / 2$ oz. 30c; oz. 50c.

GROUND GHERRY OR HUSK-Used whole for salads and preserving. Pkt. 10c; $1 / 2$ oz. 30c; oz. $50 \mathrm{c}$. 


\section{Tomatoes--Continued}

BEEFSTEAK - The fruit grows very large and very smooth. It is oval in shape rather than round like Stone. It is very solid and keeps well on the vines after ripening; has rather few seeds and ripens all over and through at one time. The color is clear deep red. Pkt. 10c; 1/2 oz. 30c; oz. 50c.

COLOSSAL-The largest of all Red Tomatoes. The Colossal will provide you with tomatoes frequently weighing two to three pounds. The solid flesh of this tomato is remarkable. There is no waste at, all and the flesh is just like beefsteak. There are very few seeds. In flavor it is simply grand. Always sweet mildly acid, melting and cool. Our Colossal should be in every garden. Pkt. 10c; 1/2 oz. 35c; oz. 60c.

ENGLISH CLUSTER-The plants are very hardy and require no more attention than other varieties. Another point of excellence is they show great resistance against blight.

The fruits grow in clusters-from nine to twentythree tomatoes growing in a single cluster and as many as ninety have been counted on one plant at the same time. The fruit is of medium size very uniform in growth, meaty, of excellent sweet flavor, making it a most desirable tomato for table use as well as preserving and canning. Pkt. 25c; oz. $\$ 1.00$.

\section{HERBS}

A few Pot Herbs and Sweet Herbs should have a place in every vegetable garden. A very small space will give all the herbs needed by a family. Culture is very simple; the best way is to make seedbed in the early spring and set the plants out in beds.

Price Per Pkt.

CARAWAY_Seeds used for seasoning........5c GATNIP ...................................... 10c. GHERVIL .................................... 10c. CORIANDER_-Seeds used for seasoning... 5c. DILL-Used for seasoning pickles............. 5c. LAVENDER-Leaves very fragrant............10 MARJORAM-Sweet.........................10c ROSEMARY - Leaves very fragrant...........10c. SAFFRON-Used for flavoring $\ldots \ldots \ldots \ldots \ldots \ldots$ c. SAGE - A highly aromatic herb ................ SAVORY Summer-Leaves and shoots used for seasoning..........................10 c. SORREL-Used in soups and salads......... $5 \mathrm{c}$. SWEET BASIL-Leaves used for flavoring... 5c. SWEET FENNEL-Seeds aromatic........... 5c. WORMWOOD-Has medicinal qualities A splendid plant for poultry...............10c.

\section{Tobacco}

Culture-The seed should be sown as early as possible after all danger of frosts in over. A good plan is to burn a quantity of rubbish and brush in the spring on the ground where the crop is to be grown, then dig and thoroughly pulverize the earth and mix with the ashes. after which the seed may be sown and covered very lightly. When the plants are about 6 inches high transplant into rows 4 or 5 feet apart each way; cultiva te thoroughly with plow and hoe.

CONNEGTICUT SEED LEAF-An old well known variety. Pkt. 10c; oz. 35c.

HAVANA-Grown from imported seed from Vuelta de Abajo. Pkt. 10c; oz. 35c.

WHITE BURLEY-well known sort. Our seed is grown on the famous limestone fields of Tennessee. Pkt. 10c; oz. 35c.

VEGETABLE SEEDS IN QUANTITY.

Market gardeners and institutions buying vegetable seeds in large quantities are requested to send us a list of their requirements, and we shall take pleasure in quoting special prices. In writing us, be sure to state quantity wanted.

DOMESTIC PARCEL POST RATES

On Seeds, Plants, Bulbs, Roots, Books, Tooles, etc. within the U. S. and Possessions.

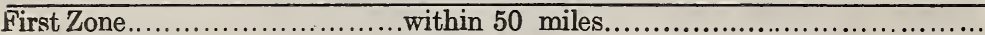

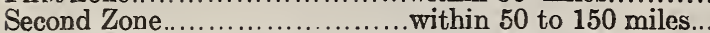

Tr.ird Zone.........................

Fourth Zone......................within 300 to 600 miles....

Fifth Zone........................within 600 to 1,000 miles.

Sixth Zone ........................... within 1000 to 1,400 miles

\begin{tabular}{l|l}
$5 \mathrm{c}$ & $1 \mathrm{c}$ \\
$5 \mathrm{c}$ & $1 \mathrm{c}$ \\
$6 \mathrm{c}$ & $2 \mathrm{c}$ \\
$7 \mathrm{c}$ & $4 \mathrm{c}$ \\
$8 \mathrm{c}$ & $6 \mathrm{c}$ \\
$9 \mathrm{c}$ & $8 \mathrm{c}$ \\
$10 \mathrm{c}$ & $10 \mathrm{c}$ \\
$12 \mathrm{c}$ & $12 \mathrm{c}$ \\
\hline
\end{tabular}




\section{TURNIPS}

The turnip is not injured by frost and makes its growth in cool moist Weather. For spring sowing plant as early as the ground can be worked and for fall sowing plant from August to October 1st in this latitude. One ounce will sow 200 feet of drill. Turnips prefer a light sandy loam. Sow in rows 12 to 18 inches apart and 1/2 inch deep. Thin out so the plants stand 4 inches apart.

EXTRA EARLY PURPLE TOP MILANFlat bulbs; develop very early in the season. They are moderate sized quite smooth and of excellent table qualities. Pkt. 10c; oz. 15c; $1 / 4$ lb. 40 c, lb. $\$ 1.00$ postpaid.

EARLY WHITE MILAN-The earliest of all. On account of its beautiful shape and extreme earliness this takes the front place among turnips. It is so smooth and neat in appearance that it gives the impression that it has been polished by hand. The foliage is scant and short. Both skin and flesh are snowy white. We have select seed of this fine variety. Pkt. $10 \mathrm{c} ;$ oz. $15 \mathrm{c} ; 1 / 4$ lb. $40 \mathrm{c} ; \mathrm{lb}$. $\$ 1.00$ postpaid.

WHITE EGG-Of handsome oval form with perfectly thin white skin. It grows very quickly and the flesh is very firm sweet and mild. Pkt. 5c; oz. $10 \mathrm{c} ; 1 / 4 \mathrm{lb}$. 30c; postpaid.

EARLY WHITE FLAT DUTCH STRAP LEAF - Matures only a week after the earliest Milan but keeps in good condition much longer. The skin is pure white the flesh is mild juicy, and of good table qualities. Pkt. 5c; oz. 10c; $1 / 4 \mathrm{lb}$. 25c; lb. 65c. postpaid.

EARLY RED OR PURPLE TOP STRAP LEAF - The standard early variety; quick-growing; flesh fine grained and sweet. Pkt. 5c; oz. $10 \mathrm{c} ; 1 / 4 \mathrm{lb}$. 25c; lb. 70c. postpaid. By freight or express, lb. $60 \mathrm{c} ; 5$ lbs. $\$ 2.50$.

PURPLE TOP WHITE GLOBE-Form large globe-shaped roots very rapidly. The upper half is of a purplish color while the lower half is of a pure white; the flesh is pure white crisp and of excellent table qualities. Pkt. 5c; oz. $10 \mathrm{c}$; $1 / 4$ lb. 25c; lb. $70 \mathrm{c}$ postpaid. By freight or express lb. $60 \mathrm{c} ; 5$ lbs. $\$ 2.75$.

LONG WHITE OR COW HORN-Roots grow half above the ground; pure white except the top. Pkt. 5c; oz. 10c; $1 / 4$ lb. 30c; lb., 80c postpaid.

LARGE YELLOW OR AMBER GLOBEGrows to a large size, and is chiefly used for stockfeeding; flesh yellow, firm and of good keeping qualities. Pkt. 5c; oz. 10c; $1 / 4$ lb., 30c; lb., $85 \mathrm{c}$, postpaid.

SOUTHERN PRIZE OR DIXIE-Makes large, round, white turnips in addition to an abundance of salad, and needs no protection. The most popular winter and spring salad turnip grown. Pkt., 5c; oz., 15c; lb., 85c, postpaid.

SEVEN TOP-Does not produce a good root, but is extensively grown in the South for the leaves, which are used for greens; very hardy and will grow all winter. Pkt.; $5 \mathrm{c}$; oz., $15 \mathrm{c} ; 1 / 4 \mathrm{lb}$., $30 \mathrm{c} ; \mathrm{lb} ., 85 \mathrm{c}$, postpaid.
IMPROVED PURPLE TOP RUTA BAGARequires a longer season in which to grow than turnips, but flesh is of superior quality and keep better. Pkt., 5c; oz., 15c; $1 / 4$ lb., $30 \mathrm{c}$; lb., 85c, postpaid.

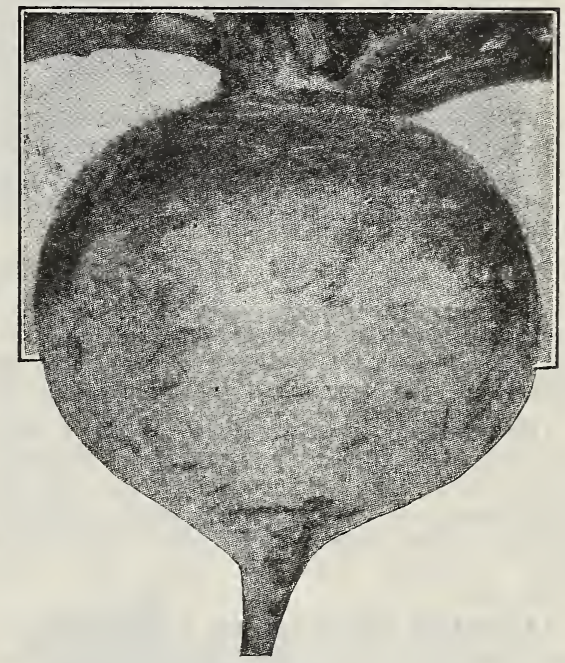

Purple Top White Globe

\section{Vegetable Plants and Roots}

ASPARAGUS ROOTS-Two-year-old roots. Doz., 50c, postpaid. By express, 100, $\$ 1.75$.

CABBAGE PLANTS-Ready after March 1st. Doz., 10c; 100 65c, postpaid. By express, $1,000, \$ 4.00$. Write us and we will give you the lowest prices on large quantities.

EGGPLANT-(New York Improved Large Purple-) Ready in Mav. Doz., 35c, postpaid. By Express, 100, \$2.75.

HORSERADISH SETS-Doz., 35c; 100,\$2.00 postpaid.

PEPPER PLANTS-(Large Sweet Bell) Ready in April. Doz., 40c, postpaid.

RHUBARB ROOTS-Strong roots, each, $30 \mathrm{c}$; doz., $\$ 2.50$. Small roots, each $15 \mathrm{c}$, doz., $\$ 1.25$, not postpaid.

TOMATO PLANTS, Transplanted-Ready in April. Doz., 35c, postpaid. By express, 100 $\$ 1.75$.

SWEET POTATO SLIPS-Write for prices. 


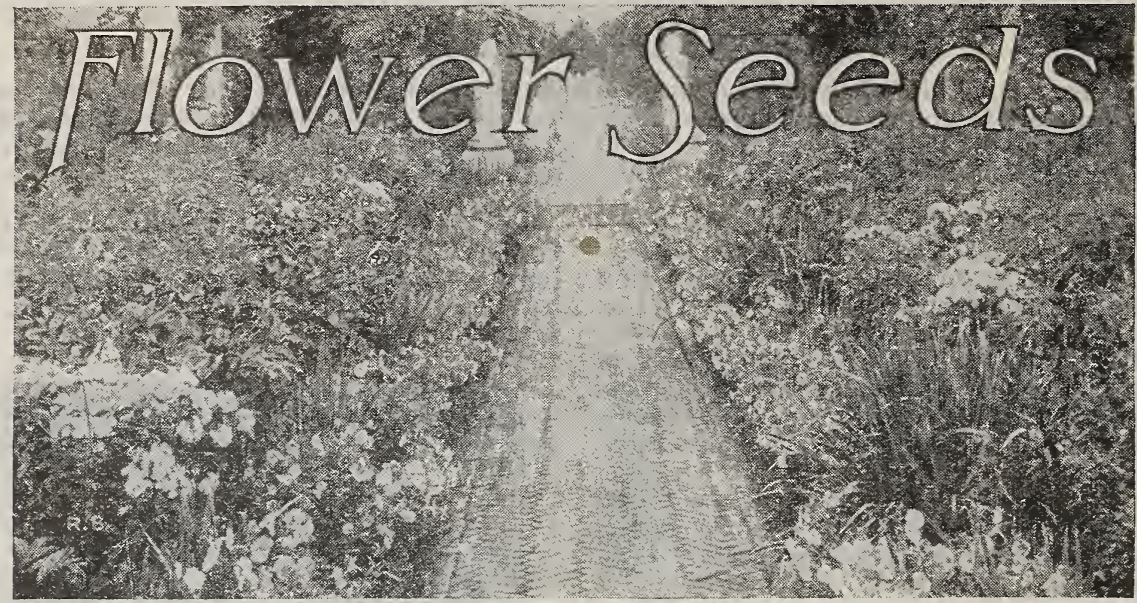

\section{SAY IT WITH FLOWERS}

No garden is complete without flowers. No home is so beautiful but what something is lacking without flowers. The beauty of a soft green carpet of grass is enhanced by a bed of waving flowers. Flowers speak a language of beauty that is understood by all.

AGERATUM (Conyzcides) - A very beautiful Mexican flower of a delicate bush-like appearance; very attractive in the garden. They bloom all summer and if sown in the fall will give winter bloom under glass. Set a foot apart. Annual, $1 \frac{1}{2}$ feet high. Pkt. 10c; $1 / 4$ oz. 25c.

ALYSSUM (Maritimum) Little Gem-A low. spreading light green plant with small

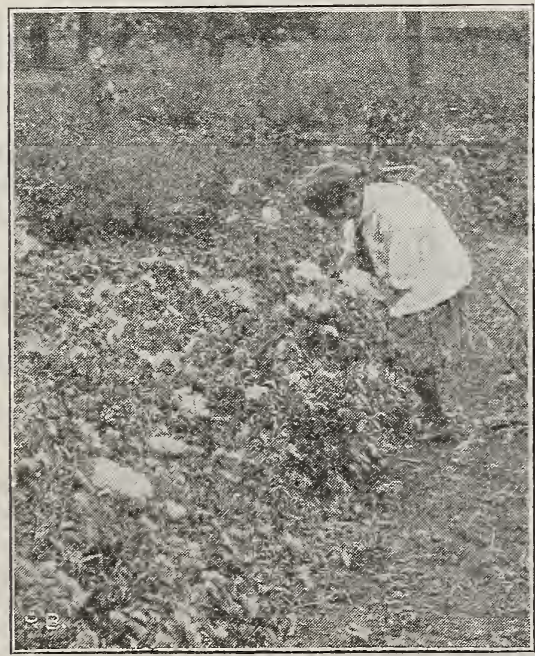

ASTERS white flowers of a peculiar delicate fragrance. Most effective in masses of plants, 1 foot apart. Hardy annual, 1 foot high. Pkt., 10c;1/4 oz. 20c.

AMARANTHUS-(Caudatus)-Foliage brilliantly ornamental, producing a striking effect in the border, as a background, or as centerpiece for beds, and is the peer of variegated plants. Annual. Should be thinned to 3 feet apart. 2 to 3 feet high. Pkt. 10c; $1 / 4$ oz., 20c.

ASTER (Composite)-The Aster is considered the queen of all flowers. For beauty and variety of form and color, it is unrivalled, and of all the flowers is best adapted to win the admiration of all lovers of floral beauty. Set a foot apart. Height $11 / 2$ feet. Annual.

PERFECTION Brand Giant Pink-Pkt. $10 \mathrm{c} ; 1 / 4$ oz. $25 \mathrm{c}$.

PERFECTION Brand Giant White-Pkt. $10 \mathrm{c} ; 1 / 4$ oz. $25 \mathrm{c}$.

PERFECTION Brand Giant Purple-Pkt. 10c; $1 / 4$ oz. $25 \mathrm{c}$.

PERFEGTION Brand Giant Mixed-Pkt. 10c; oz. 25c.

BABY'S BREATH (Gypsophila)-Per-en nial two feet. Blooms in July and August. Small flowers on branched stems so thick as to give the plants a white lacelike effect. Pkt. $10 \mathrm{c} ; 1 / 4$ oz. $25 \mathrm{c}$.

BALSAM (Lady's Slipper, Touch-me-not) -An old favorite garden flower producing its gorgeous masses of beautiful brilliant colored double flowers in the greatest profusion. Halfhardy annual. 2 feet high. PERFECTION Brand Mixed Double--Pkt. 10c; $1 / 4$ oz. 20c. 


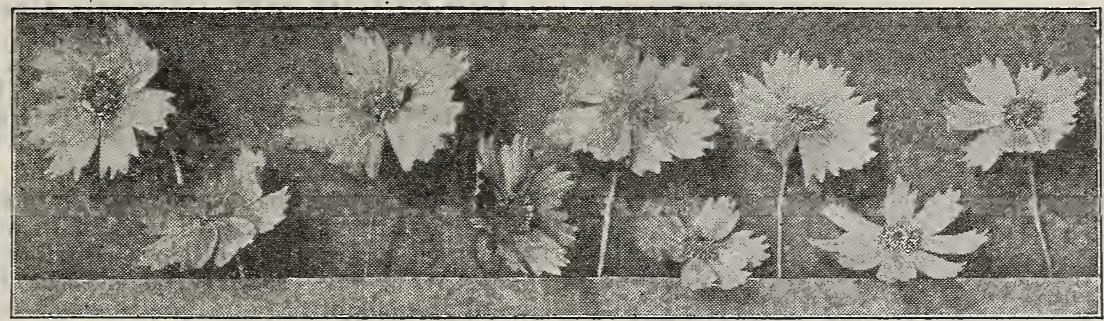

Calliopsis

CALLIOPSIS, (or Coreopsis)--Showy and fiee-flowering plants, blooming all summer and excellent for cutting and massing. Annual, 1 to 2 feet high.

PERFECTION Brand Mixed-Pkt., $5 c ; 1 / 4$ oz., 15c.

CANDYTUFT, (Iberis Umbellata)-One of the most bardy annuals, useful for cutting and is most effective when grown in a mass. As it only blooms over a limited period, successive sowings should be made at intervals of three weeks. when danger of frost is past. Sow early $1 / 4$ irch deep in fine rich soil and transplant or thin out to 9 inches apart. Height, 1 foot.

PERFECTION Brand Mixed-Pkt., $5 \mathrm{c} ; 1 / 4 \mathrm{oz}$., $15 \mathrm{c}$.

CARNATION-Marguerite-These are comparatively a new class of carnations. They are highly prized for massing in summer beds and their perfect form, beautiful shades of color and lavish profusion of bloom continue till frost. Semi-dwarf, 10 to 15 inches high. Annual. Pkt. 10c; $1 / 4$ oz., 25 c.

CELOSIA, (Feathered Cockscomb)-Annual plants of tropical origin and one of the most showy for garden decoration. Half-hardy; should not be sown till warm weather. Of easy culture.

PERFECTION Brand Mixed-Pkt., 10c; $1 / 4$ oz., 25c.

GENTAUREA GYANUS, (Mixed Bachelors Button)-One of the most popular flowers for boutonieres. It is perfectly hardy and reseeds itself, the self-sown seedlings appearing year after year. May be sown in the early spring and summer, and again in early fall for spring flowering. Of great value for cutting.

PERFECTION Brand Mixed-Pkt., $5 \mathrm{c} ; 1 / 4 \mathrm{oz}$., 10c.

CHRYSANTHEMUMS-These showy and effective garden varieties are extensively grown for cut flowers. The foliage is ornamental and finely cut. They grow 16 to 18 inches high and blossom in the fall. Annual.

PERFEGTION Brand Mixed-Pkt., 10c; $1 / 40 \mathrm{z}$ 20c.

COLUMBINE, (Aquilegia)-One of the most popular perennials easy of cultivation and flowering from early summer until frost. Very desire- able for borders and groups among sbrubbery 1 to 3 feet bigh. PERFEGTION Brand Double Mixed-Pkt., 10c; 1/4 oz., 25c.

COSMOS-Beautiful and invaluable flowering plants, blooming in the fall when other subjects are passing their best. The foliage is light and finely cut, rivaling the fern for decorative purposes. The plants continue to bloom until severe frost, producing their charming daisy-like flowers with great prodigelity. The colors are pure white, pink, and crimson.

Sow in rich soil when all danger from frost is past, and thin out the seedlings to 2 feet apart. Or, to insure early flowers, start in the house during early spring.

PERFECTION Brand Mixed-Pkt., 10c; $1 / 2$ oz., 15c.

Giant Flowered Pink-Pkt., 10c; 1/4 oz.. 20c

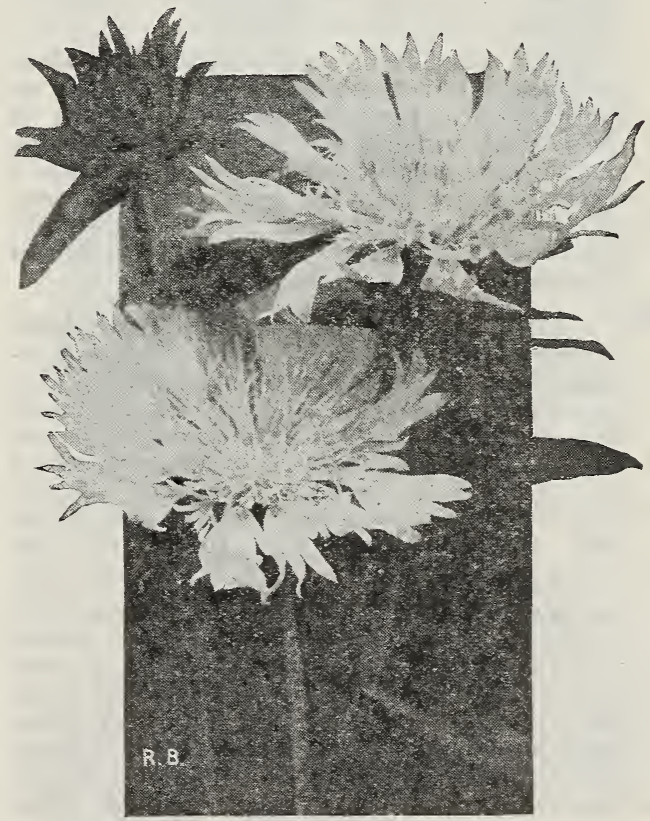

Bachelor's Button (Centaurea Cyanus) 


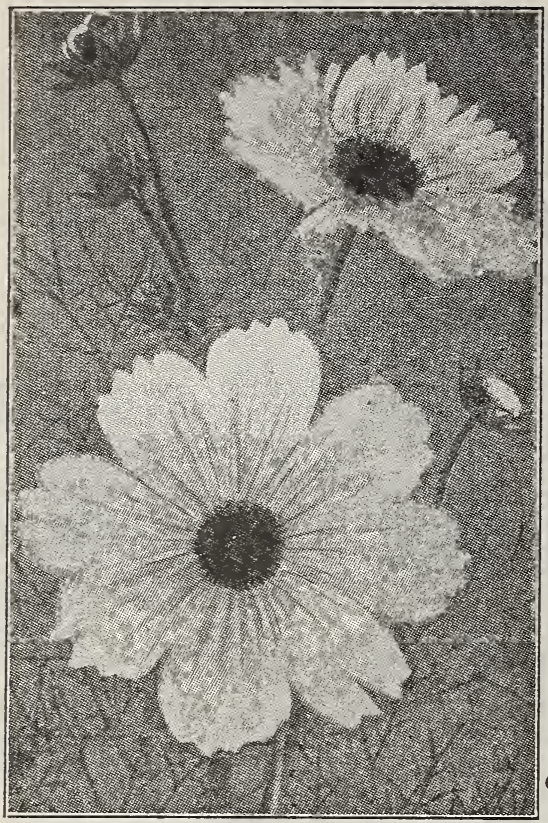

Cosmos

DAHLIA-The dablia is one of the most popular occupants of our gardens. Of great value for cut flower purposes, while for floral effects in the border they are unsurpassed.

Easily raised from seed, which will produce to flower the first season. Sow in hot bed or sunny window towards the end of March or early April, using a fine light compost, which should contain one-third leaf mould. When 2 inches high, transplant to single pots and plant out when the nights are warm. Half-hardy perennial, 3 to 5 feet. PERFECTION Brand Mixed-Pkt., 10c; $1 / 4$ oz., 30c.

SHASTA DAISY, (Chrysanthemum Leucanthemum)-Perennial Chrysanthemum, especially the Shasta Daisies, have come to stay in our gardens. They are conspicuous in mixed beds or grown in front of shrubbery and as a cut flower are without equal. They are easily raised from seed and in our latitude are most successfully treated as a biennial. Shasta Daisy is pure white, early flowering. Pkt., 10c; $1 / 4$ oz., $40 \mathrm{c}$.

EVERLASTINGS-Large, full, double, daisy like flower beads with prominent centers and stiff overlapping scales. Produces in various shades of bright yellow and scarlet on stems of good length. Desirable as dried specimens and for use in making winter bouquets. For this purpose the flowers should be gathered when on the point of expanding. Sow early in the spring; thin to one foot apart each way. Hardy annual. Two to two and one half feet high. Mixed. Pkt., 10c; $1 / 4$ oz., 25 c.
FOR-GET-ME-NOT, (Myosotis Alpestris) -The for-get-me-not is an old favorite plant, bearing clusters of star-shaped delicate blue flowers. Plants 3 to 8 inches high. Hardy perennial. PERFECTION Brand Tall Mixed Pkt., 10c; 1/4 0z., 25c.

FOUR O'CLOCKS, or Marvel of Peru, (Mirabilis)-This handsome, well-known freeflowering garden favorite does well in any soil and under almost all conditions. Produces large flowers of many brilliant colors. The flowers are at the height of perfection during the afternoon. Height two feet. Sow seeds outdoors where intended to bloom, in May. PERFEGTION Brand Mixed-Pkt., 10c; $1 / 4$ oz., 20c.

FOXGLOVE (Digitalis)-A very beautiful and interesting old-fashioned plant whose culture is very simple. The bell-shaped flowers borne on long spikes make an exceedingly handsome and stately border. Keep plants 2 feet apart. Height 3 to 5 feet. Hardy biennial. PERFECTION Brand Mired-Pkt., 10c; $1 / 4$ oz., $15 \mathrm{c}$.

GAILLARDIA, (Blanket Flower) - The perennial varieties have many daisy-like blossoms, mostly in the yellow shades with dark centers. The annual varieties are very showy and are well adapted for garden decoration and cutting.

Grandiflora, mixed. Two feet. Large flowering. Pkt., 10c; $1 / 4$ oz.,, 25c.

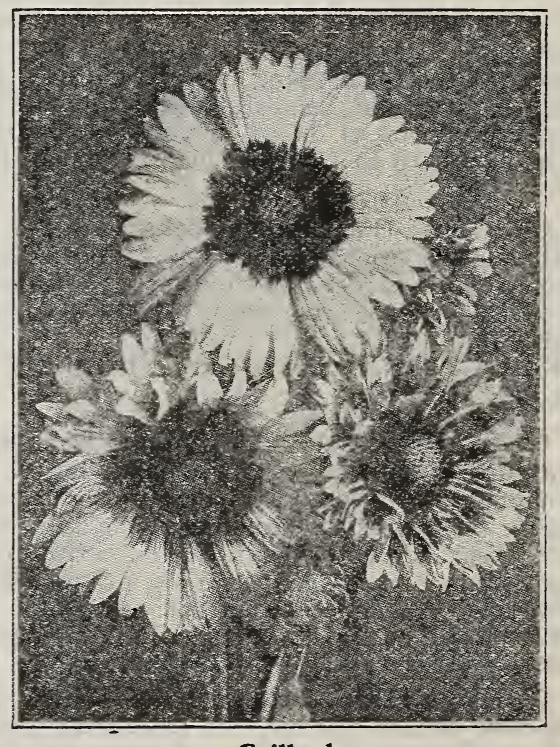

Gaillarda

GERANIUM, (Pelargonium)-These universally admired plants are easily grown from seeds and bloom the first season. Their brilliancy and succession of bloom, together with their markings, make them invaluable for either beds or pot culture. Half-hardy perennial. 1 to 2 feet. PERFECTION Brand Mixed-Pkt., 10c oz., $50 \mathrm{c}$. 
GOLDEN ROD, (Solidago Latifolia)American National Flower. Hardy perennial two to five feet. The well known golden-yellow favorite. Pkt., 10c.

HIBISCUS-Tall-growing branching plants of the easiest culture, with handsome foliage and large bell-shaped flowers measuring from 5 to 7 inches across. Blooms all season. Height 4 to 5 feet. Annual. PERFEGTION Brand Mixed -Pkt., 10c; 1/4 oz., 15c.

HOLLYHOCK (Althea Rosea)-The hollyhock is an old garden favorite. The tall stately spikes bear immense quantities of blooms, of the most brilliant colors and as double as a rose. Plant 3 feet apart and water freely. Height 5 to 6 feet. Hardy perennial. PERFEGTION Brand Double Mixed-Pkt., 10c; $1 / 4 \mathrm{oz}, 25 \mathrm{c}$.

KOCHIA (Summer Cypress)-Sometimes called burning bush. This annual plant is of surprising rapid growth, regular pyramids about 2 feet high. Leaves slender of light pea green until fall, changing to blood red and carmine. Pkt., 5c; 1/4 oz., 10c; oz., 30c.

LANTANA-Popular and rapid growing plants with large heads of variously colored and perfumed flowers. The bushy plants are completely loaded with blossoms, which are succeeded by green berries which turn to deep blue when ripe. Half-hardy perennial 2 feet high.

Perfection Brand Mixed-Pkt., 10c; $1 / 4$ oz., 20c.

LARKSPAR (Delphinium Ajaxis)-An elegant variety of this popular plant. Producing beautiful spikes of flowers in many colors which rival the hyacinth for display. The seed is better sown in autumn and thinned to 6 inches apart. Hardy annual 1 to $2 \frac{1}{2}$ feet high.

Perfection Brand ¿Double, Mixed-Pkt., 10c; $1 / 4$ oz., 20c.

LUPIN (Perennis)-Very desirable garden plants, showy and excellent for cutting. Graceful spikes 2 feet high in various colors. Annual PERFEGTION Brand Mixed-Pkt., 10c; oz. 10c.

MARIGOLD-The plants are very floriferous, becoming in fact almost a mass of color during the late summer and fall. The predominating color is yellow. marked with brown and orange. For early blooming, sow in sunny window or frame in early spring or in good rich soil in the open later. Transplant or thin out to 9 to 12 inches apart.

African Double Mixed-Pkt., 10c; 1/4 oz., 20c.

MIGNONETTE-The mignonette is a universal favorite and no other flower is so generally known for fragrance. The dense semi-globular heads of flowers on stalks about 6 inches high, making the whole plant reach to 1 to $11 / 2$ feet high. Hardy annual. PERFEGTION Brand Mixed-Pkt., 10c; $1 / 4$ oz., $15 \mathrm{c}$.

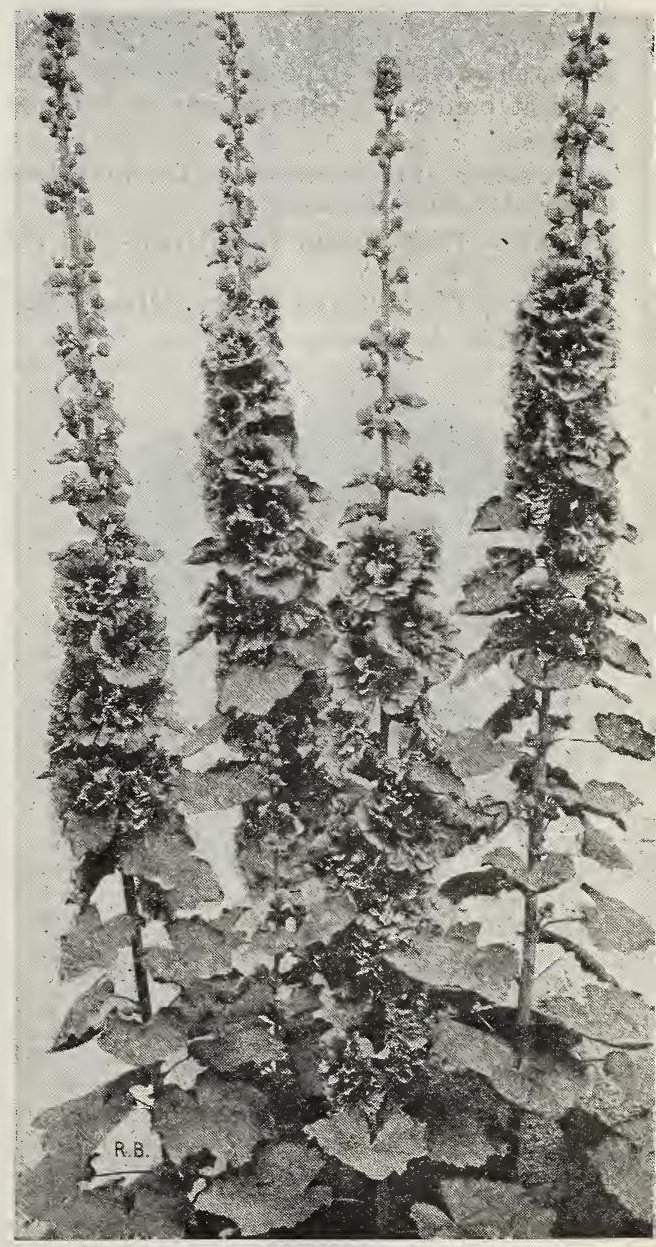

Hollyhock 


\section{Page $38 \quad$ PERFECTION BRAND SEEDS}

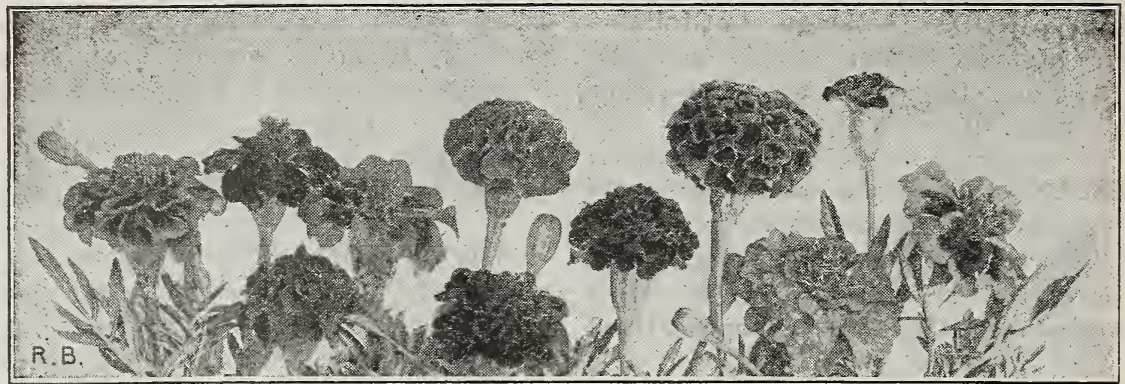

Marigold

NASTURTIUMS-We know of no flower that requires as little attention and yet gives as much pleasure as do Nasturtiums. The tall varieties can be let run on the ground or they will climb fences and trellises. The dwarf varieties make excellent borders for either vegetable or flower gardens.

The culture is most simple and the flowers are produced in amazing quantities.

PERFECTION Brand Tall Mixed-Pkt., 10c oz., 15c, $1 / 4$ lb., 30c.

PERFECTION Brand Dwarf Mixed-Pkt. 10c; oz., 15c; $1 / 4$ lb., 40c.

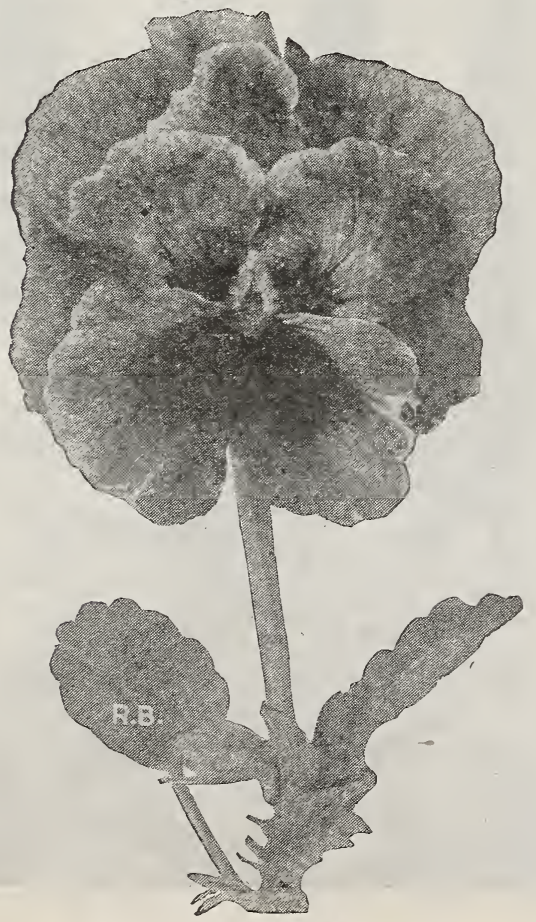

Giant Trimardeau Pansy

\section{PANSIES}

PANSIES-The pansy is a flower that is well known and highly prized in every garden. The small, dainty, highly colored little fellows are fairly easily grown and are certainly a delight either in the garden or on the table. An effective way of showing them off is to pick them with very short stems, place them in large flat, dark colored dish filled with water. The blossoms will then float on the water and if a good strain is used the many contrasting colors will display themselves to advantage.

Choice Mixed-Pkt., 10c; $1 / 4$ oz., 30c; oz. $\$ 1$.

Giant Trimardeau Mixed-Pkt. 10c; $1 / 4 \mathrm{oz}$. $40 \mathrm{c} ;$ oz., $\$ 1.25$.

PETUNIA-Petunias are unsurpassed if indeed equalled for massing in beds. Their richness of color, duration of bloom, and easy culture will always make them welcome and popular. 11/4 feet high. Hardy annual. Transplant 18 inche s apart. PERFECTION Brand Single MixedPkt., 10c; $1 / 4$ oz., 25c; oz., 80c.

Striped and Blotched-Pkt., 10c; $1 / 4$ oz., 35c.

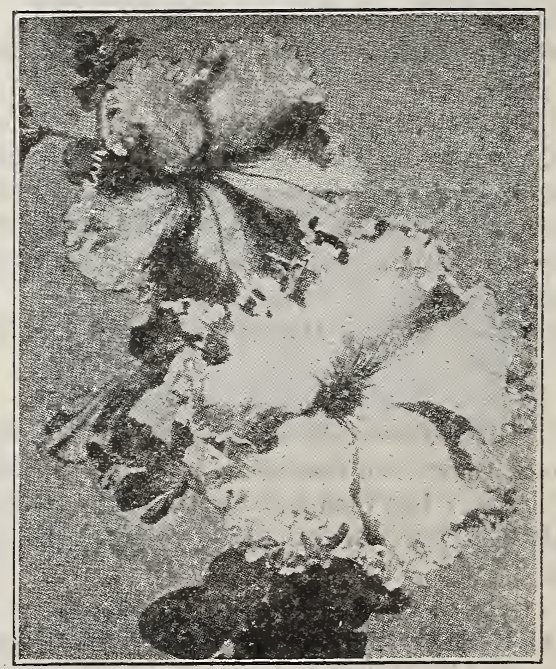

Single Petunias 
PHLOX-One of the standard bedding plants which have a place in almost every garden being unexcelled for constant profusion of bloom and diversity of colors. For early flowering sow the seeds in boxes to transplant in the border or bed when the weather is warm, and a later sowing may be made in the open ground where they are to bloom. Hardy annuals.

Phlox Drummondii Mixed-Pkt. 10c; 1/4 oz., 25c.

Star Phlox Mixed (Cuspidata)-Pkt. 10c; $1 / 4$ oz., 30c.

PERENNIAL PHLOX-These are among the finest plants for beds and borders. Mixture of all finest sorts. Pkt. 10c.

\section{Pinks or Dianthus}

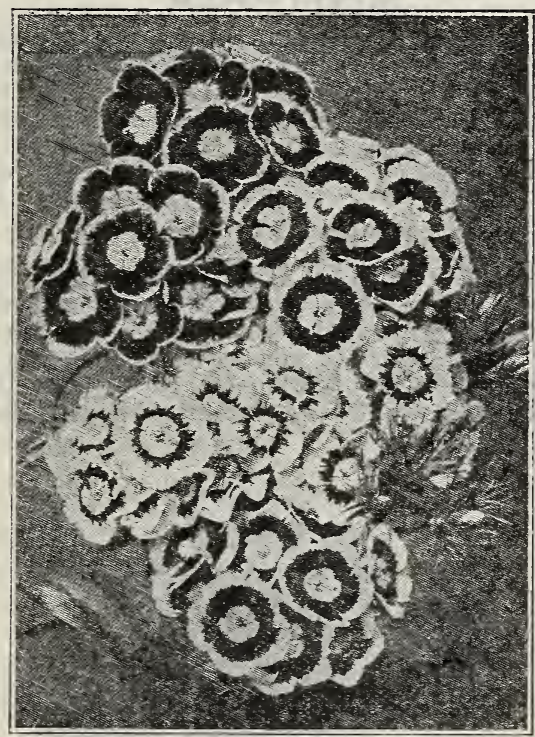

Pinks

PINKS OR DIANTHUS-A magnificent genus, embracing some of the most popular flowers in cultivation producing a great variety of brilliant colors and profusion of bloom. The varieties classed as annuals are really biennials, but are treated as annuals and may be sown out of doors, when danger from frost is past, and in a few weeks time they are a mass of bloom, continuing so until after hard frost. As a rule, they survive the winter if given slight protection, flowering abundantly the following season. They grow about a foot high and can be used in beds or borders of solid or mixed colors.

PERFECTION Brand Double Mixed-Pkt. $10 \mathrm{c} ; 1 / 4$ oz., $25 \mathrm{c}$.

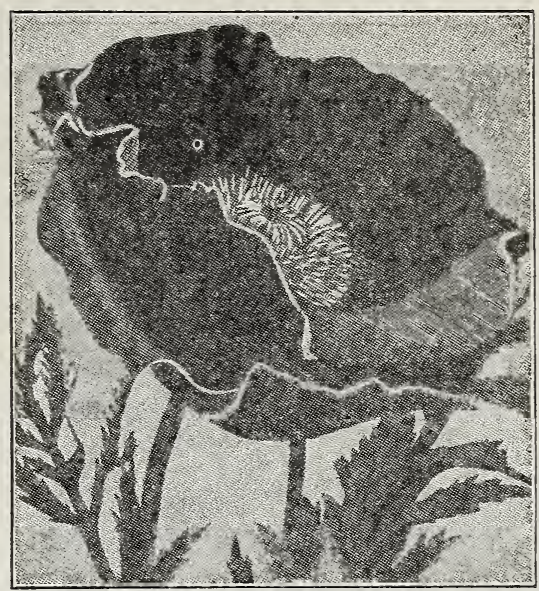

Poppy

POPPIES (Papaver)-Poppies are so wellknown that it is needless to say anything in their favor. Quite a number of the perennial varieties bloom the first vear from seed if sown early. Sowings made in May, and again several times during the spring, will produce a continuous bloom from early summer until frost. The seed should be sown where the plants are wanted to bloom, as Poppies do not take kindly to transplanting. Cover seed very lightly, and firm the soil with a flat board. When large enough thin out the plants. A sandy loam and early spring sowings produce the best flowers.

Californica Mixed-Pkt. 10c; oz., 30c.

Single Mixed-Pkt. 10s. oz. 35c.

Double Mixed-Pkt. 10c. oz. 40c.

\section{PERENNIAL POPPIES}

Mixed Oriental Poppies-For gorgeous coloring, the Oriental Poppies have few rivals among hardy plants. Their brilliant flowers produce magnificent effect, while for cutting they are invaluable. Pkt. 10c; $1 / 4$ oz., 30c.

PORTULACA - There is scarcely any flower in cultivation that makes such a dazzling display as a bed of many-hued, highly colored portulaca. In bloom all summer until frost. Beds should have full exposure to sun and plants will stand any amount of dry weather.

PERFECTION Brand Double Mixed-Pkt. 10c; $1 / 4$ oz., 50c.

PERFECTION Brand Single Mixed-Pkt. 10c; $1 / 4$ oz. 20 c; oz., 65 c.

RICINUS (Castor Bean)-This magnificent foliage plant is picturesquely sbowy and imposing, lending to the garden a truly subtropical effect. When grown single, it forms a perfect pvramid of gigantic leaves. which with the brightly colored seed pods make a perfect oriental picture. Plant 2 inches deep when all danger of frost is over. Set out or transplant 3 feet apart. $20 \mathrm{c}$. 


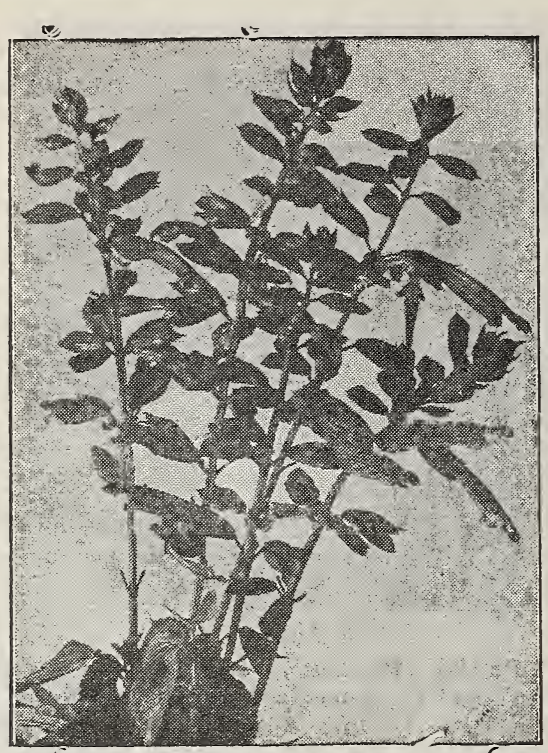

Salvia Splendens

\section{SALPIGLOSSIS}

SALPIGLOSSIS-A very showy bedding or border plant from July until early autumn. The exquisite beauty of the flowers with their rare combination of colors is a revelation. Transplant to a foot apart. Half-hardy annual, 11/2 to 2 feet high. PERFEGTION Brand Mixed -Pkt., 10c; $1 / 4$ oz., 20c; oz.. 60c.

\section{SALVIA}

SALVIA (Scarlet Sage)-One of the handsomest flowering plants we have for garden decoration, blooming in spikes from midsummer until killed by frost. Their compact bushes, literally ablaze with brilliant flowers, really have no rivals. About 3 feet high. Half-hardy perennial. Splendens-Pkt., 10c; 12 pkts., $\$ 1.00$.

\section{SCABIOSA}

SCABIOSA (Mourning Bride)-Well-known garden favorite, flowering freely from midsummer until frost. The handsome double flowers are borne on long stems, thus adding to their value as cut flowers, while the colors range from pure white through shades of pink and red to blue and black-maroon. Sow $1 / 4$ inch deep in rich soil, as soon as the ground is in good condition, when all danger from frost is past. Thin out the seedlings 6 to 8 inches apart. Seed may also be sown in frames or sunny windows for early blooming. PERFEGTION Brand Mixed -Pkt., 5c; $1 / 4$ oz., 10c; oz., 35c.

\section{SNAPDRAGON}

SNAPDRAGON (Antirrhinum Majus)The snapdragon is an old favorite border plant with dark, glossy leaves and large curious-shaped flowers, having finely marked throats, and are borne on tall spikes. Half-hardy perennial, 2 feet high. PERFECTION Brand Mixed Tall -Pkt., 10c; $1 / 4$ oz., 20 c.

\section{STOGKS}

STOGKS (Gilliflower)-A magnificent group of plants extensively cultivated for both summer and winter decoration. The extreme beauty of their flowers and luxuriant foliage, combined with their neat, graceful habit, makes them one of the most popular and useful for pot culture and bedding purposes.

PERPECTION BRAND--Large flowering mixed Pkt. 10c; $1 / 4$ oz. 30c.

\section{SUNFLOWER}

SUNFLOWER (Helianthus)-They do well in sunny positions, in any kind of soil. Seeds may be sown in the open ground as soon as the weather is suitable, or indoors in March andApril and later transplanted. California Fi P1 Double, golden yeilow. Pkt., 5c; $1 / 4$ oz., 10c.

\section{SWEET WILLIAM}

SWEET WILLIAM (Dianthus Barbatus)A well-known attractive, free-flowering plant, producing a splendid effect in bed and borders, with rich, attractive flowers borne in heads or clusters about 18 inches high. Hardy perennial. PERFECTION Brand Double Mixed-Pkt., $10 \mathrm{c} ; 1 / 4$ oz., $25 \mathrm{c}$.

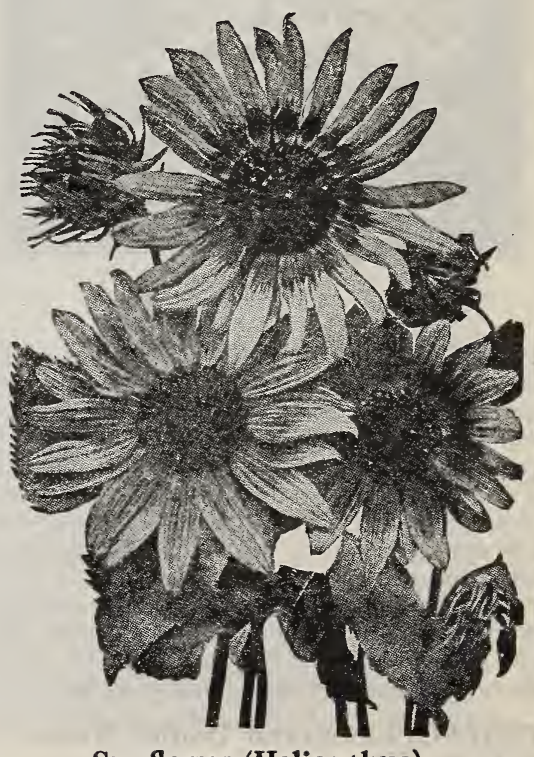

Sunflower (Helianthus) 
THUNBERGIA ALATA (Black-Eyed Susan) -A very charming and beautiful rapid-growing vine, useful for window boxes baskets or trailing over banks, etc. It blooms most profusely the entire season until frost comes the flowers being pure white, buff, orange with large dark eyes.

PERFECTION Mixed-Pkt. 10c; $1 / 4$ oz. 30c.

VERBENA HYBRIDA-One of the most beautiful occupants of our flower gardens. Blooming freely all season until frost and in the most brilliant colors. Admirable for solid beds or masses; also for edging. Sow $1-8$ inch deep in boxes or pots of fine soil, transplant to other boxes 3 inches apart, and plant out in a warm, sunny position in the border when all danger from frost is past. PERFECTION Brand MixedPkt. 10c; $1 / 4$ oz. 30c. oz. $\$ 1.00$.

Verbena Defiance-Scarlet. Pkt., 10c; 1/4 oz. 30c.

VINCA (Madagascar Periwinkle)-Handsome ornamental free-blooming very bushy plants producing round, single flowers measuring $11 / 2$ inches across. One of the most satisfactory flowering bedding plants; also a fine cut flower. PERFEGTION Brand Mixed-Pkt. 10c; $1 / 4$ Oz. 30c; oz. 90c.

WISTARIA-Hardy climbing plants making a rapid growth with purple flowers.-Pkt. 5 c; $1 / 4$ oz. 10 c; oz. 30 c.

ZINNIA (Elegans)-This plant is one of the most brilliant and showy annuals. It bears large double flowers from early summer till frost with very little attention. Provide plenty of room, at least 18 inches. Height 2 feet. Annual. PERFEGTION Brand Double Mixed-Pkt., 10c; $1 / 4$ oz., 20c; oz., 50c.

Grimson Double-Pkt. 10c; $1 / 4$ oz. 25c; oz. 70c.

\section{Flowering Vines}

Rapid climbers are excellent to shade porches cover stumps and hide unsightly places. Everyone who has a porch or room that is exposed to the hot sun all summer long will appreciate what it would mean to have a dense green vine for protection.

BALLOON VINE-Climbing vine of rapid growth with whiteflowers and seed vessels which resemble miniature balloons. Light warm soil suits them best. Hardy annual. Pkt. 10c; oz., 30c.

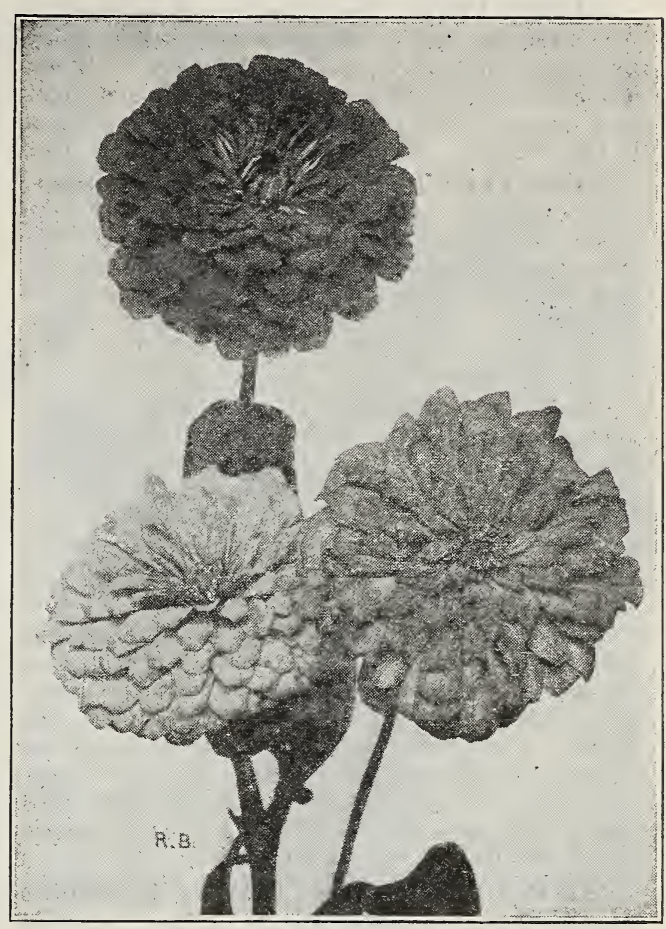

BALSAM APPLE (Momordica Balsamina) - Very curious rapid, and dense climber with ornamental foliage. Its large golden yellow fruit opens when ripe and displays its brilliant blood-red inside. Hardy annual. 10 to 20 feet. Pkt. 10c; oz. 25c.

CYPRESS VINE (Ipomoea Quamoclit)A most beautiful climber with delicate dark green, feathery foliage and an abundance of bright flowers. Planted by the side of a veranda, tree or stakes, it attains a height of from 10 to 20 feet. Annual.

Mixed-Pkt. $5 \mathrm{c} ; 1 / 4$ oz. 10c.

Red-Pkt. 10c; $1 / 4$ oz. 20c.

\section{Glematis}

CLEMATIS (Paniculata)-One of the finest hardy perennial climbers. Pure white fragrant flowers. The flowers are followed by pretty seed pods of bronzy-red. Twelve feet. Pkt. 10c.

HYAGINTH BEAN (Dolichos Lablab) (Commonly known as Jack Bean.) A splendid climber with hyacinth-like clusters of flowers, which are followed by exceedingly ornamental seed pods. Is of rapid growth and stands heat well but not the cold. Half-hardy annual, 10 to 20 feet high. Pkt. $10 \mathrm{c} ; \mathrm{oz} .25 \mathrm{c}$. 
KUDZU VINE-“Jack and the Bean Stalk." A remarkably fast growing vine with large green leaves and clusters of pea-shaped flowers. When well established will grow from forty to sixty feet in a season. The plant dies back to the ground in the winter. Hardy perennial. Pkt. 10c;

MOONFLOWER (Evening-Glory Ipomea) -Moonflowers are the most gorgeous and versatile of the climbing plants. It does well trained along the roof of a low house or veranda, and its blossoms are delightfully fragrant. If the seed are notched they will bloom six weeks from sowing. Annual. Wbite Seed-Pkt. 10c; $1 / 4$ oz. 20c; oz. 50c.

MORNING GLORY (Gonvolulus Major) -One of the most free-flowering and rapidgrowing annual climbers thriving in almost any situation. Its delicate flowers are very brilliant and beautiful with a wide range of tints and markings. Annual. Supply a support early; use either wire or cord or trellis. Height 10 to 15 feet. Japanese Imperial-Pkt. $10 \mathrm{c} ; \mathrm{oz} .15 \mathrm{c}$.

ORNAMENTAL GOURDS-Interesting and attractive when grown on trellis, pergola, or fences, etc. Of very rapid growth with luxuriant foliage and bearing most curious-shaped fruits. The ground should be very rich and six or more seeds sown in a place, $1 / 2$ inch deep; thin out to two best plants. Do not sow until the ground is warm. Gather the fruits before frost. Mixed-Pkt. 10c; oz. 25c.

SCARLET RUNNER BEAN (Phaseolus Multiflorus)-A tall twining plant, covered with crimson blossoms. As an ornamental vine over trellis, arbors, etc., very popular. Annual, growing 12 to 15 feet high. Pkt. 5c; oz. 10c.

WILD CUCUMBER-Rapid growing vine with bright green foliage and clusters of white flowers. One of the best annual climbers for covering old fences, trellises, etc. Soak the seed in water for twenty-four hours before sowing. Pkt., 10c; oz., $20 \mathrm{c}$.

\section{SWEET PEAS}

Sweet Peas are more than flowers, they are a necessity for every garden. They lend themselves readily and easily to beautifying schemes of the city and country farmer.

Location. Any location will be suitable that is wèll drained and that will get free circulation of air. Farly planting is essential with sweet peas in order to give the roots a chance to develop more rapidly than the tops during the cool weather. Early plantings produce blossoms before the intense heat of the summer comes which is likely to wilt the plants if they do not have well developed roots. Sowings should be made in furrows 12 inches deep and the seed covered with an inch of soil and the trench filled in as the plants grow. It is a help to soak the seeds in luke warm water over night before sowing. Use one ounce to twelve feet of row.
Spencer Sweet Peas-Because of such unusual size,waved or fluted appearance and charming blendings of harmonious colors. The new Spencer type may be appropriately described as Gigantic Orchid Flowered. The flowers are not only of extremely large size, but are distinct in having the outer edges of the standard and wings beautiful crumpled or waved.

Countess Spencer-Soft rose pink.

Florence Morse-Blush Pink.

King Edward-Deep rich carmine.

Juanita-Striped Lavender.

White Spencer.

Royal Purple.

All of the above 10c per packet; oz. 40c; $1 / 4$ lb. $\$ 1.25 ; 1$ b. $\$ 4.00$.

PERFECTION Brand Spencer MixedSweet Peas-Pkt. $10 \mathrm{c}$; oz. 25c; $1 / 4 \mathrm{lb} .60 \mathrm{c} ; \mathrm{lb} . \$ 2$.

PERFECTION Brand Grandiflora Sweet Peas Mixed-Pkt. $10 \mathrm{c} ; \mathrm{oz} .15 \mathrm{c} ; 1 / 4 \mathrm{lb} .35 \mathrm{c} ; \mathrm{lb}$. $\$ 1$.
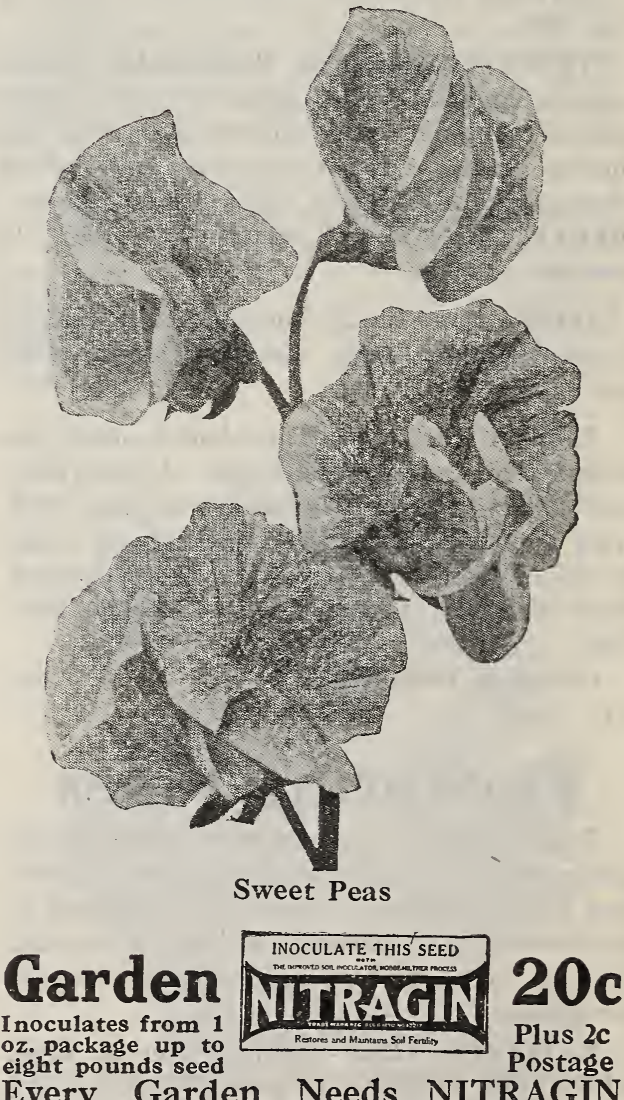

Every Garden Needs NITRAGIN (3 in one) Bacteria Fertilizer for Peas, Sweet Peas and Beans 


\section{Cannas}

BULBS FOR SPRING PLANTING

BURBANK - The flower opens like a lily with stiff petals and is four to five inches across, of a fine bright yellow with red spots in throat. Profuse bloomer. Yellow truss flowers. Green foliage, height 3 to 4 feet. Each, 10c; doz., 90c.

KING HUMBERT $-4-5$ feet. Bronze foliage Flowers large, five to six inches across. Flower a glowing scarlet or orange-red, often streaked with gold. Each, 15c; doz., \$1.25.

LOUISIANA (Pennsylvania)-Five to six feet. Green foliage. Flower a deep, vivid crimson, often with a crinkley edge and always with a silky sheen. Each, 10c; doz., \$1.00.

FLORENCE VAUGHAN-Rich golden yellow, dotted with bright red, Height, 5 feet. Each, 15c. Dozen, \$1.25.

WEST GROVE-Flower moderately large, 4 to 5 inches across, but with rather narrow petals. Large truss. Color a deep pink or faintly salmon pink. Pink truss flowers, green foliage. Height 3 to 4 feet. Each, 15c; doz., $\$ 1.25$

YELLOW KING HUMBERT-Four feet. Foliage a very dark green with flowers measuring five to seven inches across. Color of flower a deep rich yellow heavily spotted and blotched with bright red. Each, 20c; 3 for 50c.

\section{Elephants Ear}

GALADIUM ESGULENTUM-Known to almost everyone. A number of stems come from a single bulb, growing 4 to 5 feet high, with a single leaf, which often measures 18 inches or more across. Put out early in spring in rich soil, give plenty of water, and it will be a pleasure to watch its development through the season. Large bulbs. Each, 25e; postpaid, 35c.

\section{Splendid Bedding Plants}

Postpaid

Asters,PerfectionBrand,GiantMxd. $\$ 0.50$

$\$ 4.00$

Cosmos, Perfection Brand, Mixed... . .50

4.00

Larkspur, Double Mixed, Tall...... .65

Petunia, Double Mixed............... 1.00

Petunia, Single Mixed................ .50

Phlox, Drummondi, Mixed........ .50

Pansy Giant Trimardeau, Mixed.. $\quad .60$

Salvia Scarlet Sage................. .75

Snapdragon, Tall Mixed............ .65

Verbena Defiance, Scarlet............ .75

Verbena, Mixed...................... .65

Vinca or Periwinkle, Mixed .......... .75

ZinniaPerfectionBrandDoubleMxd $\quad .50$

Zinnia,Perfection Double Crimson $\quad .50$

5.00

8.00

4.00

4.00

4.75

6.00

5.00

6.00

5.00

6.00

4.00

Moonflower, White, each 20c.

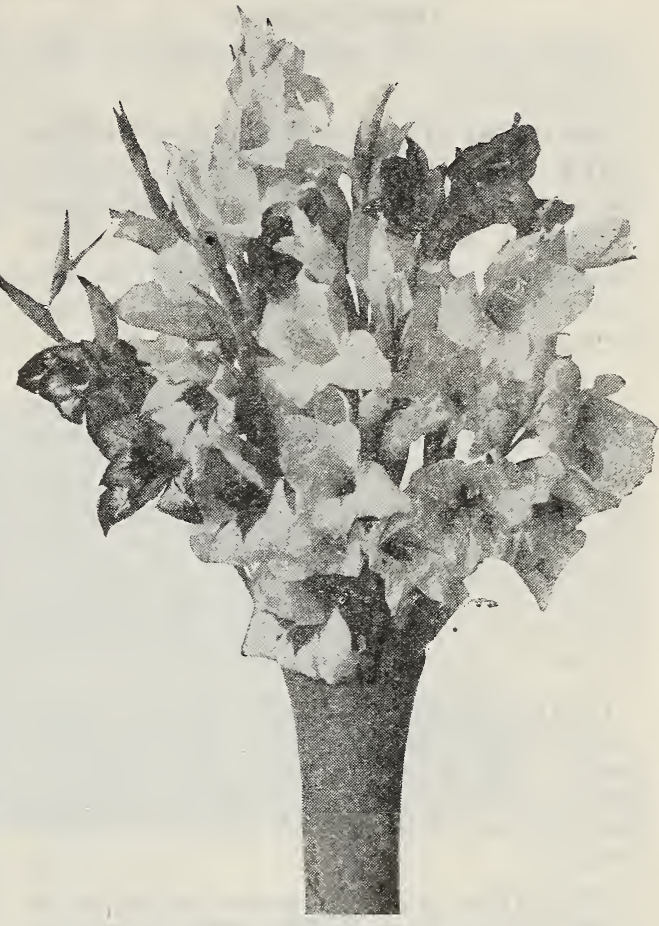

Vase of Mixed Gladioli

\section{Decorative Dahlias}

Strong Field Grown Division.

BERG VAN HEEMSTEDE-Soft Citron Yellow. 45c each, postpaid.

CATHERINE DUER-Beautiful Crimson Scarlet, 45c each, postpaid.

DELICE-Best pure bright rose pink. 45c each postpaid.

PRINGESS JULIANA-Clear White. 45c each, postpaid.

Mixed Colors-Each 25c, postpaid.

\section{Selected Gladioli}

AMERICA-The Well known pink. 10c. each; 85c dozen, postpaid.

ANNIE WIGMAN-Soft yellow. 10c each; 85c dozen, postpaid.

BARON J. HULOT-Deep violet blue $10 \mathrm{c}$ each; 90c, dozen, postpaid.

MRS. FRANGIS KING-Scarlet, 10c each; 85c dozen, postpaid.

GLORY OF HOLLAND-Pure White, 10c each; 85c dozen, postpaid.

Mixed-7c each, 60s dozen, postpaid. 


\section{Insecticides--Fungicides--Disinfectants}

\section{INSECTICIDES}

Please note that poisons cannot be sent by Parcel Post.

RED SNAPPER PLANT SOAP, with SULPHUR and NICCOTYL-Kills the insects. Keeps plants thrifty. Fish oil soap suds drives the insects away. Extract of tobacco kills by contact and absorption. Sulphur is the standard for mildew, scale and fungi. Per $1 / 2$ pound package, $25 \mathrm{c}$.

SLUG SHOT-Slug shot, used from ocean to ocean. A light composite, fine powder, easily distributed either by duster, bellows, or in water by spraying. Thoroughly reliable in killing currant worms, chicken lice, slugs, sow bugs, bugs on cantaloupes, cucumbers, etc., and it is strongly impregnated with fungicides. Packed in cartons of 1 pound each, with perforated top to dust out, $20 \mathrm{c}$, each; 5 lb., pkg., $70 \mathrm{c}$.

GRAPE DUST-A readily diffusible, lightweight powder fungicide; very efficient in destroying mildew and in preventing blights in green-houses or in the open; also for destroying the aphis and black fly. Lb. carton, 25c; 5-lb. bag, 70c.

HOFSTRA-A non-poisonous insecticide for Home, Farm or Store. Kill flies, mosquitoes, ants, bed bugs, roaches, mites, lice, fleas, potato-bugs, and cabbage worms. Spray Hofstra on flowers vegetable plants, fruit and shade trees for certain insects. Pkgs. 25c; 50c and $\$ 1.00$.

DEVOES "SURE NOXEM"-Insecticide and fungicide. For the control of many leaf eating insects. Use on cabbage, cauliflower, tomato plants, gooseberry bushes, and other vegetables and shrubs. Price, lb., duster, 20c; 5-lb., package $55 \mathrm{c}$ each.

TOBACCO DUST-For green and black aphis, fleas, beetles, etc. Splendid fertilizer and preventive for insects in the ground and around roots. For insects on plants, apply with powderduster or bellows; for worms or grubs in the soil, apply liberally to the surface and rake or strew thickly in drills before planting. lb., 10c; 100 lbs., $\$ 6.00$.

ARSENATE OF LEAD POWDER-Cannot be mailed) The best known and most extesnively used stomach poison for insects. It is safe to use on most plants, possesses good adhesive qualities, shows white when sprayed and owing to its fineness remains in suspension well in water. For general use, $1 \mathrm{lb}$., to 50 gallons of water, or 3 teaspoonsful to 1 gallon of water. Price, lb., 50c; Ask for special prices in larger lots.

PARIS GREEN-(Cannot be mailed.) ' Apply dry or in solution of water. Paris Green is a strong and the best known poison for potato bugs, half price, $1 / 2$ lb., 25c; 1 lb., 45c. Ask for prices on larger lots.

LIME SULPHUR POWDER-Used as a dormant spray against scale insects. Has certain fungicidal properties, use 10 to $12 \mathrm{lbs}$. to 50 gallons water. lb., 30c; 10 lbs., $\$ 2.00$. Ask for special prices on larger lots.

BORDEAUX MIXTURE POWDER-(Cannot be mailed.) For blight, mildew, rust and fungus diseases. For ordinary use it takes 6 lbs. to 50 gallons of water; for peach trees and trees with tender foliage use $6 \mathrm{lbs}$ to 65 to 70 gallons of water. Price lb., 40c. Special prices on larger lots.

CUTWORM FOOD-The one best food for the destruction of cutworm. It is simple and easy to use. It consists of as material that is more delicious and is much more preferred by the cutworm than the plants themselves. It is sprinkled on the ground around the plant just as it is found in the package. For plants started from seed, it is applied as soon as the first plants break ground; for plants started in a seed-bed, it is applied just after setting, such as tomato, cabbage, egg plant, cauliflower, tobacco and flowers. The one-pound package is a very convenient size to use for small gardens and flower-beds. Directions how to use on each package. lb., pkg. 35c.

BLACK LEAF 40-The insecticide so highly recommended by Experimental Stations, Destroys aphis (plant lice), thrips, leaf-hoppers on all tree, bush and vine fruits, vegetables, field crops, flowers and shrubs; without injury to foliage. You can not go wrong by ordering Black Leaf 40 for sucking insects. Price, oz. (makes six gallons spray) 35c; $1 / 2$ lb., $\$ 1.25$.

\section{Niagara "ALL IN ONE"}

A combination of materials suitable for controlling many fungus diseases, many chewing insects and many sucking insects on vegetable plants, trees, shrubbery and vines and is particularly valuable for controlling blight, mildew, red spot, all aphis, ants, mealy bugs, and bugs on chrysanthemums, peonies, etc. Is an ideal insecticide for all chewing and sucking insects on flowering plants. Price 1b., 50c, Ask for special prices on larger quantities. 


\section{Farm Seeds}

It behooves the grower to plant the very best seeds obtainable. Realizing this, it is our aim to offer the best. We contract our seeds from reliable growers in the country, who have made the growing of seeds their life-long work, and whose reputation is at stake. Then again, all seeds brought into our house are thoroughly inspected and tested before offering them,and it is necessary they come up to our high standard before we place them on the market. Our years of experience in the seed business, and methods of testing, enable us to offer nothing but first-class stock, which the grower demands and is entitled to, as the planting of inferior seeds may mean the loss of his time, labor, and money, and an entire crop.

Prices on all farm seeds subject to market fluctuations. We urge that you write us your needsand it will be a pleasure to us to quote you the very lowest prices on Perfection Brand Seeds. Remember, we are here to serve you in any capacity we can.

\section{Seed Corn}

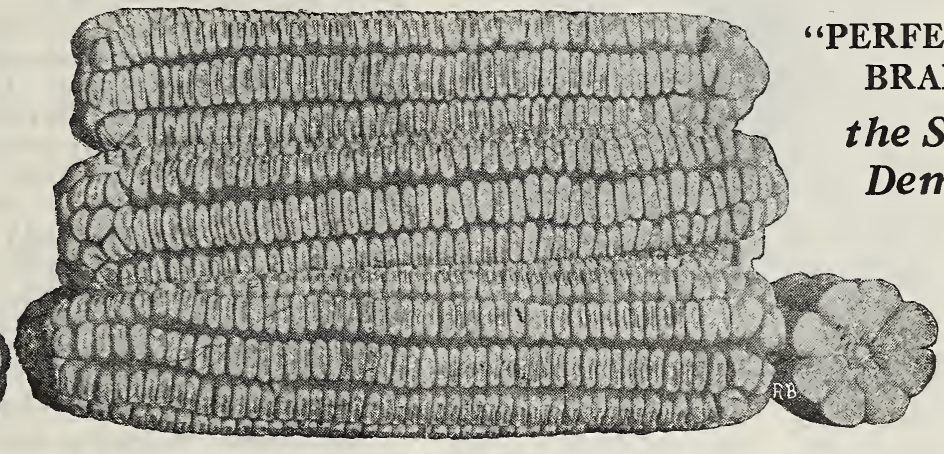

Hickory King Corn

Our stocks are grown in Iowa, Arkansas, Kansas and Oklahoma, by reliable growers.

The Iowa corn is what might be termed commercial stocks for early maturing corn. Our native corn is especially graded, tipped and butted. All are of high germination. Samples gladly mailed on request.

Our Dwarf Mexican June Corn is absolutely the best sort for late crop. Plant during May, June and July. If your spring crop has not been a success, due to unfavoroble weather conditions, you can plant Mexican June Corn as late as July 15.

No other variety of corn has the drouth resisting features of our Dwarf Mexican June Corn. The stalks under favorable conditions grow 6 to 8 feet high, and the yield range 30 to 60 bushels per acre. Of a strong growth, it sends its roots deep into the soil enabling it to resist drouth and hot summer winds better than any other sort.

\section{Northern Varieties}

Pound postpaid; peck (14 lbs.) not postpaid. Iowa Goldmine-90 days, lb., 20c; Peck $\$ 1.00$. Early Adams-75 days, lb., 20c; peck, $\$ 1.50$. Squaw Corn-80 days, lb., 20c; peck, $\$ 1.00$.

Iowa Silver Mine-90 days, lb., 20c; pk., $\$ 1.00$. Reid's Yellow Dent-90 days, lb., 20c; pk., \$1. Champion White Pearl-90 days, lb., 20c; pk., \$1.00.

ST. CHARLES WHITE-Red Cob, 120 days, lb., 20c, pk. $\$ 1.00$

\section{Native Varieties}

Reid's Yellow Dent-90 days, lb. 20c.

Golden Beauty-120 days, lb. 20c.

Bloody Butcher-120 days, lb. 20c.

Silvermine -90 days, $\mathrm{lb} .20 \mathrm{c}$

Squaw Corn-100 days, lb. 20c.

Hickory King-110 days, lb. 20c.

Hastings Prolific-110 days, lb. 20c.

Calico or Strawberry-120 days, lb. 20c.

Dwarf Mexican June White-100 days, lb.

20c.

All the above-peck $\$ 1.00$, bushel $\$ 3.50$. 


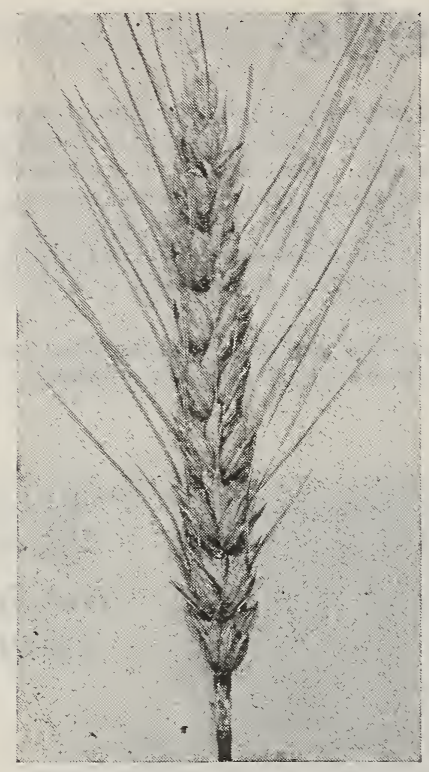

MANSURY BARLEY-It is an early sixrowed variety with strong, bright straw, bearing long, well filled heads of plump grain, ripens medium early. Sow two bushels to the acre. Market price variable. Will quote price on request.

BUR TOR EARLY WHITE MAY OATS We have found that Burt oats is one of the best for spring sowing. It is one of the earliest, if not the very earliest, of the spring oats. This gives it a long seeding season as it may be sown anywhere from the middle of February to April 15th. Our sales of this have increased largely during the last few years. The prices of oats vary. Write us for prices when you are ready to sow. Bu. $\$ 1.00$.

RED RUSTPROOF OATS-Very early; is rustprooff; does well on thin ground and does not lodge; will bear neglect or a bad season and still make a good crop. We offer only the genuine Texas Red Rustproof. Bu., 80c. Write us for prices on large quantities.

FULGHUM OATS-This is a strain of the Red Rustproof Oats grown more especially for its earliness, maturing as it does some two weeks ahead of the native strains enables you to have them cut before the native oats mature and reaching the market two weeks earlier command better prices. Fulghum Oats also make excellent winter pasture, they have an unusually heavy hay and do not winter-kill readily. It is a remarkable rust resistant and hardy in every respect. Write for prices.
KANOTA OATS-is a superior strain from Fulghum oats. Is five days earlier makes heavy yield, straw is stiffer and rust resisting. Supply limited, while they last, $\$ 1.25$ per bushel.

\section{COTTON SEED}

\section{PEDIGREED MEBANE'S TRIUMPH} Write for prices.

\section{POP GORN}

QUEEN'S GOLDEN-A fine yellow sort; pops perfectly white and very large; immensely productive: shelled.By mail, lb., 25c; by freight or express, lb., 20c; 10 lbs., $\$ 1.50$.

WHITE RICE-The most popular sort and the best. By mail, lb., 20c; by freight or express, lb., 15c; 10 lbs., $\$ 1.25$.

JAPANESE OR HULLESS-A splendid white corn, productive, having very little hard center or hull when popped. By mail, lb., 25c; by freight or express, lb., 20c; 10 lbs., $\$ 1.75$.

WHITE PEARL-Very productive; medium kernel, smooth, white, attractive. By mail, lb., 20 c; by freight or express, lb., 15c; 10 lbs., $\$ 1.25$.

\section{BUCKWHEAT}

Buchwheat is used mostly for filling fields unplanted after the first of June. The blossoms furnish a large amount of honey for bees. It is well to remember that on worn-out soils a plowed-under buckwheat field is a great fertilizer and improver. Sow $25 \mathrm{lbs}$ to an acre.

JAPANESE-A popular and standard sort. Very large grains of dark brown color; early and heavy-yielding. Choice recleaned seed. Pk., \$1.

SILVER HULL-A very prolific and early sort. Grain light gray in color. A favorite with millers on account of the white flour it produces. Pk., $\$ 1.00$.

\section{SEED RYE}

NORTHERN GROWN-Rye does best on rich, sandy soil; almost a sure crop every year. Should be sown in August or September; $11 / 2$ bushels per acre. Write for prices.

ABRUZZI RYE-Abruzzi rye has again proved its superiority for growing all through the south. It is fully a week to ten days earlier in maturity than the ordinary rye. It makes a quick, vigorous growth. Matures its grain decidely in advance of other kinds. It is only necessary for farmers to plant a field of Abruzzi by the side of a native variety to have a demonstartion of the superiority of Abruzzi in yield and plant growth.

The quality of Abruzzi rye is among the highest of all feeding crops-not as a hay crop but as a grazing crop. It grows upright, stools heavily, and does not lie flat on the ground, all of which makes it easy for the animals to graze. Cattle relish this green winter crop.

\section{Write for Quantity Prices.}




\section{Possible Failure of Soil Inoculation}

Inoculation, while giving striking benefits, is by no means a cure-all for soil troubles. The bacteria concerned require satisfactory soil conditions if they are to flourish, in a very sour soil they do poorly and their growth can readily be improved by lime. If a farmer is uncertain regarding the acidity of his soil, it is well to have the soil tested before seeding leguminous crops. For a legume, as f or any other crop, the seed-bed should be well prepared, the soil well drained, and its acidity neutralized by the use of lime.

\section{Dwarf Essex Rape}

Sow 5 to 7 pounds per acre. With the exception of alfalfa, Dwarf Essex Rape is the most valuable forage plant that has ever been introduced in the United States. As a healthy fattening food it has no equal. It stands without a rival in point of cheapness and feeding qualities. It is an annual, bearing a close resemblance in leaf and stalk to the rutabaga, but both leaves and stalks are more numerous in the rape plant and of a taller habit of growth. Dwarf Essex rape thrives best on a good soil rich in vegetable matter. Slough lands are excellent. It is the simplest crop grown. It can be sown anywhere and everywhere and at all times after danger of frost has passed.

It may be sown in early spring to provide summer pasture for stock. Plow the ground same as for turnips, and sow 5 pounds per acre broadcast, It can be sown with corn at last plowing and makes a good summer pasture after corn is cut. Every farmer should sow enough for summer pasture and save his grass pasture for fall and winter. Special prices on large quantities. Lb., 25c; postpaid. By freight or express, lb., $20 \mathrm{c} ; 10$ lbs., $\$ 1.40$.

\section{Soy Beans}

Soy beans are very erect, growing with from one to six stems or more, branching out from the roots, and reaching a beight of $11 / 2$ to $31 / 2$ feet; seldom falling down, except in very rich, loose soil. Soy beans are a remarkable drouthresister, and will do comparatively well on thin land; however, they respond very readily to moisture and rich land. Planting should not be done until the weather is warm and after the corn-planting. Soy beans as feed will take the place of oil or gluten meal. Feeding them to cows or hogs will bring astonishing results. If broadcast, $1 / 2$ to 1 bushel per acre. Lb., 20c; postpaid; by freight or express, lb., 15c; pk., 15 lb. $\$ 1.50$.

\section{Vetches}

Sand Vetch-(Also called Winter and Hairy Vetch)-This legume is the farmer's ever ready friend. Sand vetch is a very valuable forage plant, and is rapidly becoming popular as year after year farmers are learning more of its value. It is an annual, but resows itself, and will come up year after year on the same ground. Vetch is a legume, belonging to the pea family, but the vines are much longer and the foliage more abundant. It is noted for its extreme hardiness, wintering more certainly than wheat. It remains green all winter under the snow, and is ready for pasturing earlier than anything else. Drouth, heat and cold do not effect it. It is largely eaten by all kinds of stock. We earnestly recommend farmers to try it. Write us freely for any information you may require. Lb., 35c; postpaid. By freight or express, lb., 25c.

Vetch for Hay or Pasture-It yields a surprising amount of feed. Ten tons per acre are not unusual, as it makes an enormous growth. For cutting it should be sown with oats in the spring or with rye in the fall. Vetch is quite spreading, and the grain furnishes support so it can be be mowed readily. Like clover, cow peas, and alfalfa, it is very rich fodder, especially suited to milk production, as well as for growing stock. One especially good point is that it is ready for pasture extremely early in the spring. It grows rapidly and is particularly valuable in fields where clover does not thrive. When sown in April or May, it can be cut in July for hay, and the second growth will provide abundant pasture during the summer. For hay, it should be cut promptly when the first setting of the pods has filled.

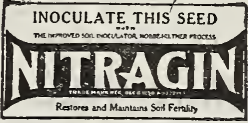

\section{The Speckled Velvet Bean}

The new 100-day speckled bean originated in south Alabama. It is exceedingly hardy, which is a most desirable feature in the earlymaturing soils, the pods staying in the field in good condition all winter, where they are used as pasturage for cattle and hogs. The bean can be grown over the entire South, and is one of the most profitable as well as less expensive crops ever produced by the Southern farmer.

It can be planted in rows with corn without injury to the latter, 5 or 6 feet apart in drills. When planted this way it invariably produces twice as much grain per acre as corn - of a higher analysis, to say nothing of the fertility it adds to the soil. Velvet beans are considered by many as one of the best legumes. They may be successfully grown on almost any soil. Land 


\section{Speckled Velvet Bean-Continued}

that has been run down or worn out from growing cotton for a number of years may be readily restored to its original fertility by growing this legume. They are among the best known for cattle and hogs and one of the most profitable grown for this purpose. Cattle will gather and get fat on it in the field is the best form of fertilizer. One of the principal factors in soil life is humus which is abundantly supplied by this legume. Humus in soil keeps it in condition to let in the rains more readily; helps to absorb and hold it; lessens baking and packing; prevents washing and bleaching; making plant-food in soil available; and is very necessary in the development of nitrogen-gathering bacteria. It also adds to the soil phosphorus, potash, and nitrogen. Nitrogen costs us, when bought, 15 to 20 cents per pound. It is estimated at about four-fifths, or about that proportion, of the air. Is this expensive? Lb. 20c, postpaid; by freight or express, lb., 15c; pk., \$1.45. Write for quantity prices.

\section{Field or Cow Peas}

The Great Soil Improver-Makes poor land rich; makes good land more productive; also makes a splendid and nutritious green forage or hay crop, enriching the soil even when the crop is cut off. Cow peas make one of the largest yielding and most nutritious crops grown. There is also no surer or cheaper means of improving and increasing the productiveness of the soil and it is really considered more economical and the best way to cut off the crop of vines and cure them as a forage or hay crop and then turn under the stubble and roots. Even when the crop is cut off, the land is left in very much better mechanical condition and the productiveness very much increased over what it was before the crop was grown.

Cream Crowder Peas-It is not only one of the earliest to mature, but also makes a largeand vigorous growth, and is one of the most prolific and best for edible peas, both for home use and market. The size of the pea is large and they are of most delicious flavor when cooked, and preferable for table use to other varieties. This also makes a quantity of vine. Price, lb., 30c, postpaid.

BLACK-EYED PEAS-A very fine table pea much in demand by market gardeners. Pods are of good size and the peas are crowded in the pod. Ask for prices.

NEW ERA-Probably the best sort for the West and North; can be sown after the wheat is taken off the ground and still produce a good crop of forage peas, besides increasing the fertility of the soil for the succeeding crop, and leaving the ground mellow and free from weeds. Ask for prices.

WHIPPOORWILL PEAS-A favorite in Oklahoma, Texas, and in the South generally. A vigorous, healthy grower, yielding an abundant crop of forage and grain. Write for prices.
CANADA FIELD PEAS-These field peas are entirely different from cow peas, requiring to be sown early in the spring and making the crop in May or June. They are increasing in popularity every year, making a most satisfactory and early-yielding forage crop. They can be sown in open weather in December, January, February and March, in the South and make large yields of nutritious food, which can be used either green or be cured for hay. They can be sown at the rate of $11 / 2$ to 2 bushels to an acre; but a light seeding of rye, oats, or barley will increase the yield and help support the pea vines when the crop comes to maturity. Ask for prices.

MUNG BEANS-Mung Beans bid fair to outrival anything yet discovered as a hay, forage and soil improving crop. Mung Beans are drouth resistant and have made wonderful crops of hay and forage where cow peas and soy beans have been killed off completely by the blistering and withering heat of an extended summer's drouth.

Mung Beans mature about fifteen days earlier than soy beans and cow peas and invariably have produced larger tonnage of hay and forage as well as large production of beans. Grows 4 to 6 feet tall and is one of the finest soil improvers discovered. 2 lbs. of Mung Beans will produce about 2 tons of cured hay. Requires about 4 lbs. per acre. Plant in rows about $31 / 2$ feet apart and 2 to 4 inches apart in the rows. Trial Packet, 10c; lb., 40c; 5 lbs., $\$ 1.75$, postpaid. Larger quantities, write for prices.

The Improved Soil Inoculator, Nobbe-Hiltner Process

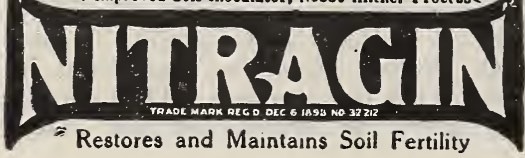

We are large dealers in Cow Peas and are in a position to quote you attractive prices in lots of one bushel to a car-load. Write us. If you have Peas to sell, send us sample stating quantity you have to offer. Make up and send us your order early. 


\section{Peanuts}

Culture-Prepare the ground well, laying it off in rows with a shovel-plow; the rows should be $31 / 2$ feet apart, and put two kernels to the hill, which are about 1 foot apart. Cultivate thoroughly, and keep the land as level as possible. Three-fourths of a bushel of unshelled nuts will seed an acre.

MAMMOTH JUMBO-This variety grows to an astonishing size. The plants make compact bushes about 18 inches high, with heavy, erect stalks and large leaves. The giant nuts have thick, heavy-ribbed shells. Lb., 35c; postpaid. Write for prices in quantities.

TENNESSEE RED-The finest variety grown. Especially adapted to the black waxy land, as well as the sandy soil. The nuts contain three large kernels in each pod, and are enormously productive. Lb., 35c, postpaid.

SPANISH-In addition to their value for growing for nuts, these are very largely used in the South as a forage and fattening crop for hogs and other stock. They are early to mature, very productive, and in the far South, where they can be planted during March and April, two crops can be made in one year, the second crop being planted early in July, the tops making a hay crop and the nuts a grain crop. They grow..more compact than the Virginia peanuts, making it possible to grow them closer, making cultivation easier also. This variety frequently yields 60 bushels of marketable peanuts and 2 tone of hay per acre. I.b., 20c, postpaid.

\section{ARTICHOKES \\ JERUSALEM ARTICHOKES-Any South-}

ern farmer who grows hogs and does not have Artichokes to feed to them is missing the profit he should receive. Jerusalem Artichokes fatten hogs quickly. (See letter on page 21 of this catalog) and it is said by some that hogs fed on Jerusalem Artichokes have never been known to have cholera. Three to four bushels are sufficient to plant an acre. The tubers should be cut into small pieces and not more than two or three to the hill. Rows should be $3 \frac{1}{2}$ to 4 feet apart and hills one to two feet. Three hundred bushels to an acre is not an unusual crop. Some farmers say Milk cows do well when fed the roots and stalks. Plant during March and April. Prices, lb., 30c; 5 lbs., \$1.25, postpaid. Ask for price on larger quantities.

\section{Sunflower}

\section{MAMMOTH RUSSIAN-Produces very}

large heads, which are completely filled with the striped grains. It succeeds everywhere, and requires very little rain to insure a good crop. It makes a large yield. It makes a good food for stock and can not be equaled as a food for poultry. Plant when the ground has become warm at the rate of 22 pounds to the acre. Lb., $35 \mathrm{c}$, postpaid; by freight or express, lb., 25c; 10 lbs., $\$ 1.75$.

\section{Our Field Seeds are all of Very High Quality}

There are several grades of field seeds on the market and prices differ according to grade. Be careful when buying, especially when you see seeds offered for considerable less than market value.

\section{Ask for Prices When You are Ready to Buy}

\section{Clover}

RED CLOVER-The most important and best known of all clovers, being used for pasture, hay, and enriching the land. For the latter purpose it is considered the cheapest fertilizer known. Lb., $40 \mathrm{c}$, postpaid. By freight or express, lb., 35c.

GRIMSON CLOVER-This is a variety, of clover that has attracted a great deal of attention in the cotton region for the past few years but the position which it will finally hold is still uncertain. It does remarkably well in Louisiana, Mississippi, and other Southern states. It is an annual, which begins its growth with the autumn rains, often givlng good grazing from November to April, when it matures its seed and dies. On favorable soils, it seeds itself, even though the ground be plowed and used for shorter summer crops like millet. Every farmer ought to plant a few acres in crimson clover. Its value is tremendous, being the best early forage and soil-improving crop we know of. Plant during August, September, October, and November at the rate of 15 to 20 pounds to the acre. It is very desirable to plant it either just before or after a good rain, as otherwise a poor stand often results. It thrives best on loose, sandy soils, and does not make a satisfactory growth on stiff or wet or poorly drained clays. It does well on poor lands and in this respect is better than red clover, adding more fertility to the soil than any other clover. It is very valuable to grow with other crops, and is often combined with rye, oats and other grair $s$ and planted in the fall by our planters. Sowing may be made in both corn and cotton fields. It is not hardy for more than one season, and must be sown every year. Inoculation is of high importance and many failures are doubtless to be attributed to lack of proper bacteria. Lb., 35c; postpaid. By freight or express, lb., 30c; 10 lbs., $\$ 2.75$.

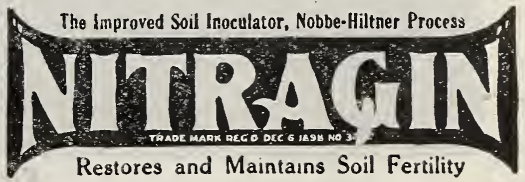




\section{Glovers-Continued}

ALSIKE OR SWEDISH GLOVER-The bead are globular, very sweet and fragrant and much liked by bees, which obtain a great amount of honey from them. It produces a great amount of herbage during the season; the stalks are rery fine; it makes a valuable hay crop where other clovers fail. Sow from 4 to 6 pounds per acre. Lb., 40c, postpaid; by freight or express, lb., 35c.

WHITE CLOVER-For lawn purposes this is very desirable on account of its creeping stems. It spreads rapidly and acts as a binder; very hardy; in permanent pastures is of considerable value. Lb., $75 \mathrm{c}$; postpaid.

\section{MAMMOTH OR SAPLING GLOVER-} (Also called Pea Vine or English Clover)-Similar to red clover, but of ranker growth and blossoms three wecks later. It will grow on many soils where the small red would prove a failure It will grow on poorer clay soils, on sandy soils, in the stony wcod, and will grow farther South than the June or common red clover. Where clover is to he sown for turning under for soil improvement, the Mammoth is by far the best as it not only roots much deeper, making a wonderful root-development. but its tap-root acts as a sub-soiler, thus putting more organic matter in the soil than can be had from the June or many other clovers. Lb., 45c; postpaid. By freight or express, Lb., $40 \mathrm{c}$.

\section{JAPANESE CLOVER OR LESPEDEZA-} Lespedeza is a summer annual that begins its growth in the middle of the spring, but dces not reach maturity until September or October. It grows successfully over the whole area from central New Jersey and southward to the Gulf.
When once established it re-seeds itself from year to year. Sow in the spring after ground warms up by scarifying with a disc harrow. Sow not less than one bushel of Lespedeza per acre of the very best re-cleaned seed obtainable; roll the field or cover seed lightly. Lespedeza and Bermuda grass mixed with Burr clover make a most excellent summer pasture. On good level land, no better hay than Bermuda can be grown. Sow the Lespedeza seed on the Bermuda sod in March or April and throughly harrow the sod. Or you can sow Lespedeza on the oats or other winter grain this spring. When the grain is ready, cut for hay or grain; let the Lesepdeza grow and make a good crop of fine hay this fall, then as the Lepedeza reseeds itself you have a permanent pasture.

Lespedeza is a legume, especially adapted to old, worn-out pastures and neglected fieldsbuilds them up and makes them profitable. Can be sown with profit on hillsides and stop that washing. All stock relish it.

Lespedeza in some soils grows 20 to 30 inches and will yield two or three tons per acre. Of course, if lands are very poor when sowed with Lespedeza you can not expect such large yields as above, but Lespedeza will enrich that poor land and will make it valuable-make it especially adapted to future cotton or corn crops. Lb., $45 \mathrm{c}$, postpaid. Write for prices on quantities.

\section{ALFALFA}

ALFALFA -is the most profitable crop by far, grown in Kansas, Oklahoma, Texas, New Mexico, Arizona, Colorado, Idaho, Utah, Wyoming and Nebraska. No other crop on a twenty year average produces nearly as many dollars per acre as does Alfalfa. In some parts of these states it is impossible to raise hogs at a cost that will permit selling them on the market and make a profit for the grower unless he can pasture the young pigs on Alfalfa.

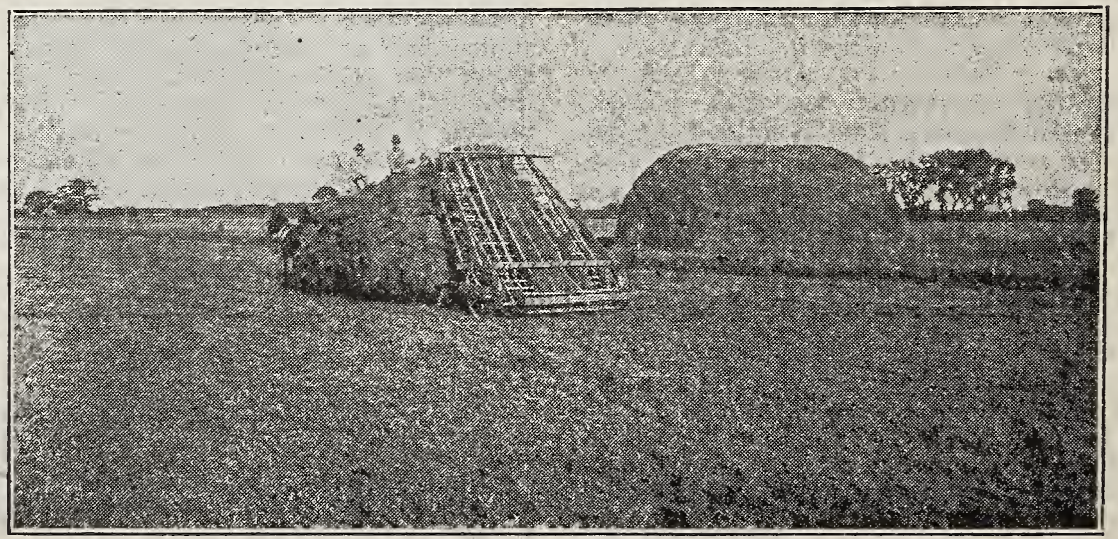




\section{Alfalfa}

It is not safe to pasture sheep, cows, or other cattle on Alfalfa, because it has a tendency to cause bloat with the consequent loss of cattle. Horses, mules and colts may be pastured on Alfalfa if necessary to use it for that purpose. Mony horse breeders pasture their mares and colts on Alfalfa throughout the growing season. Alfalfa furnishes the cheapest feed possible for this purpose.

Poultry will also thrive on Alfalfa, and it makes a very desirable addition to their feeding ration.

Many people believe that Alfalfa cannot be profitably produced in the particular section of the country where they live. We bave been shipping Alfalfo seed into thirty-six states for many years and also to several provinces of Canada, as well as to Mexico. In all of these different sections, under widely different conditions of culture, farming etc., Alfalfa hos given satisfactory results for the farmers using it. We, therefore feel certain that Alfalfa can be grown in practically every state in the United States, and that it will prove just as profitable to the farmers in the other states as it does to those in Kansas and Oklahoma. Cultivation is very simple, the essentials being well drained soil, at least eight feet to permanent water, shallow planting through barrowing and packing

Perfection Brand Alfalfa Seed is the highest grade of American grown seed, testing 99.50 $\%$ pure. Per pound, 45c; postpaid. By frt. or express, lb., $40 \mathrm{c} ; 10 \mathrm{lbs}$., $\$ 3.50$. Write for speccial price in quantities.

\section{Sweet Clover}

Sweet clover is a crop that is hardy; defies wet and drouth: never winter kills, and will grow on land that will not produce Alfalfo. Many wet, waxy soils are being farmed unprofitably by other crops, that would produce a large crop of Sweet Clover, and furthermore Sweet Clover will turn that poor land into land that will within four or five years be nearly 100 percent better for any other crop that the farmer wants to put there.

Sweet Clover has long, deep roots that permit water and air to penetrate to the lower levels of the soil and thus greatly aids the mechanical condition of the soil. As Sweet Clover is a legume it increases the nitrogen content of the soil. Wheat Corn or Alfalfa grown on a field following. Sweet Clover are greatly improved. Yields of 10,15 , and 25 percent increase are not at all uncommon.

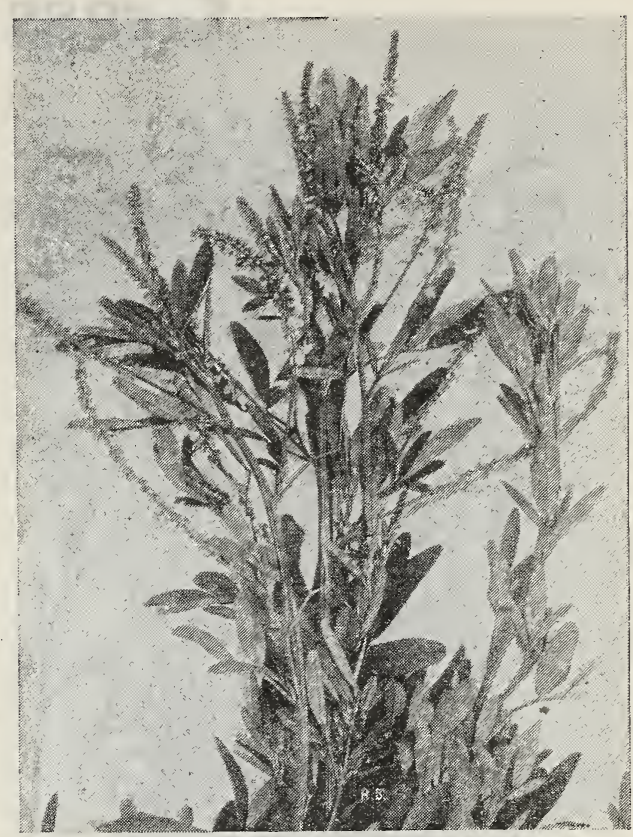

\section{Sweet Glover In Blossom.}

If you have a piece of upland or a few acres in the bend of a creek, sow Sweet Clover on it. Just disk the ground and harrow the seed in. Do not cover deeply. Sweet Clover still maintains its wild nature to the extent that it is capable of taking care of itseli. Many good stands of Sweet Clover in the prairie parts of Kansas were sown in the grass without any cultivation whatever and have proved very profitable to the owner If the field is to be grazed, stock can be allowed on it when the plants are six inches high. Sweet Clover is a biennial and not a perennial. That is, the plant grows only two years, so that this plant must be given a chance to re-seed itself the second year.

For hay and pasture Sweet Clover contains the some relative proportion of protein as Alfalfa does. Cattle, sheep, hogs and horses canall be pastured on Sweet Clover without danger of bloating. The hay will be coarser than Alfalfa and not as saleable on the market, but will contain just as much nutrition and just as much food value as alfalfa.

It can be sown either in the Spring, or Fall and it takes about twenty pounds of hulled seed to the acre-35c per pound postpaid. Write for prices in quantities. 


\section{Grass Seeds}

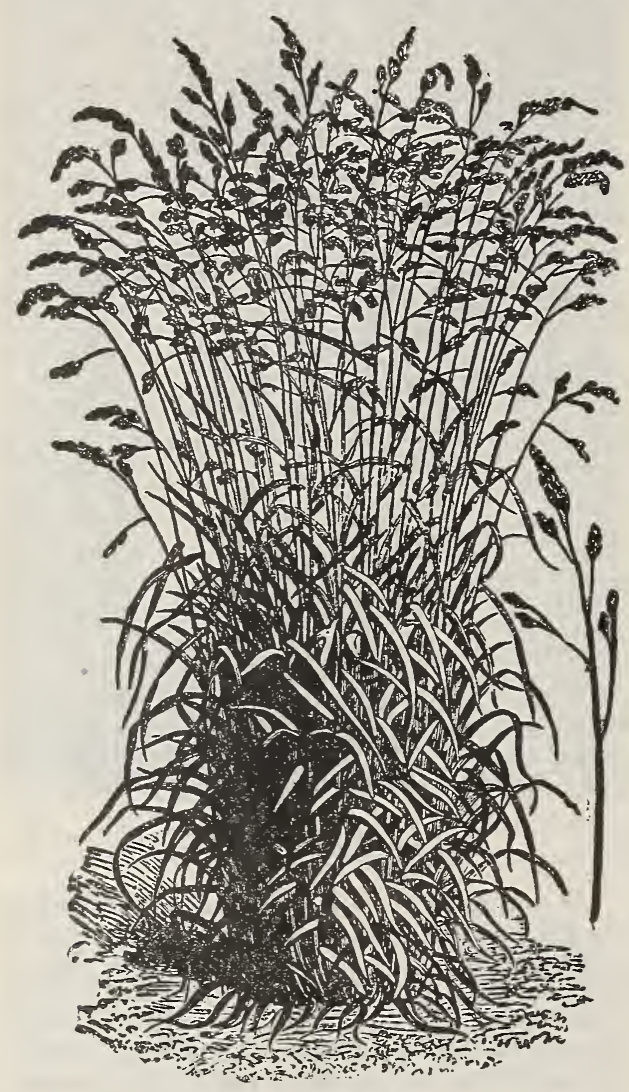

Orchard Grass

TIMOTHY - The most popular, nutritious, and salable hay grass. There are better grasses for pasture, but none for hay. Grazing close does not injure the second year's crop. Write for prices, stating quantity. Lb., 25c, postpaid; by freight or express, lb., 15 c; 10 lbs., $\$ 1.25$.

KENTUCKY BLUE GRASS-An excellent pasture and lawn grass, succeeding best on limestone land, but does well on stiff or clay soils. It is rather sensitive to heat, but not to cold weather; and on this account does best in the spring, fall or winter. It does splendidly at first-forms a compact turf, making fine pasture when once established. It is best, however, to combine other grasses with it for either lawn or pasture. Sow in the fall or spring at the rate of 2 or 3 bushels to an acre. Lb., 65c, postpaid; by freight or express, lb., $55 \mathrm{c}$.

MEADOW FESCUE, OR ENGLISH BLUE GRASS-We regard this as one of the most valuable grasses as it adapts itself to different conditions of soil and climate. Especially suited for permanent pasture; also fine for hay. It gives a large amount of early and late pasture, and when cut for hay yields from 2 to 4 tons of fine quality and very nutritious feed. It is a persistent grower; its roots penetrate deeply; it does well on wet or dry bottoms, hillsides, gravelly clay, and loamy lands. It never freezes out or winter-kills and is not easily affected by drouth Sow 15 to 25 pounds per acre. Lb., $50 \mathrm{c}$, postpaid; by freight or express, lb., $45 \mathrm{c}$.

RED TOP-Grows well in all soils, whether sandy, thin, dry lands or rich, wet soils. It is one of the most satisfactory grasses that can be sown; a fine pasture grass and is well suited for meadows. It sends out shoots at the base that take root at every joint, forming a dense, thick sod. Red Top is of great value for sowing in gullies or in soils that are inclined to wash from heavy rains. Sow 10 pounds to the acre. Lb. $45 \mathrm{c}$, postpaid; by freight or express, lb., 35c; 10 lbs., $\$ 2.75$.

BERMUDA GRASS-Bermuda is a Southern grass. It delights in sunshine and warmth. It is extensively cultivated in this section of the country for lawns. It is a small, creeping, hardy perennial, which thrives on nearly all our soils, though, like other grasses, it gives better results on richer soils. The upright flower stems vary in height from a few inches to 2 feet-according to the richness of the soil. The leaves, which are short and numerous, grow near the base of the plant. Bermuda grass is very valuable for pasture, as well as for hay crops. It grows vigorously during the hot summer months when other grasses are parched and dead. It is very difficult to eradicate when once established. One of the chief reasons why this grass has not been more extensively introduced is the fact that it has been the practice to propagate it from the roots, as it does not mature seed in this section. However, it is just as easy to get a good stand by sowing seed. The seed should be planted in the spring. Seed require 60 to 90 days to germinate. The ground should be well prepared with a good, firm seedbed, as the seed is small, and is seeded broadcast at the rate of 10 pounds per acre. Do not cover more than half an inch. The seeding should not be done too early, as the seed will not germinate if sown before the weather and ground have become warm. Lb., $85 \mathrm{c}$, postpaid; by freight or express, lb., $75 \mathrm{c} ; 10$ lbs., $\$ 7.00$. 


\section{Grass Seeds}

ORCHARD GRASS-This is one of the most valuable and widely known of all pasturage grasses, coming in early in the spring and remaining green later in the fall than any other. It grows about $21 / 2$ feet high, producing an immense quantity of leaves and forage; blooms like red clover, making it a most valuable hay. Sow $11 / 2$ bushels to an acre, either spring or fall. Lb., 40c; postpaid. By freight or express, lb., 30c.

Special Directions About Sowing-Nearly all grass seeds are very small and will not come up satisfactorily unless put in properly, and,

\section{Sudan Grass}

SUDAN GRASS-The heaviest-yielding, most drouth-resisting hay grass ever introduced. Sudan grass combines all the good features of Johnson grass and has none of the objections. Sudan grass is sown in the spring, as soon as danger of frost is past, either broadcast or in rows so that it can be cultivated. If in rows, $31 / 2$ feet apart, 5 to 6 pounds to the acre will be required; if sown broadcast, 15 to 20 pounds. It stools freely and often from 80 to 100 plants may be found coming from one seed. As a drouth-resister, it has no equal, and may be depended upon when all other grasses sucumb to dry weather. It may be mowed or cut with a binder; the latter method is preferred, as Sudan grass cures admirably well in shocks. Lb., 25c, postpaid. Write for prices in larger quantities.

\section{KAFIR}

The uplands of Kansas, Oklahoma and Texas will give much better cash returns when planted to Kafir, because Kafir when ground for feed gives practically the same feeding value as Corn. The fodder value of Kafir is much higher than corn fodder and it produces a larger tonnage per acre. We are offering several types or varieties of Kafir. Any of them will give good good results on proper soil and under ordirary moisture conditions. It does not require very much Kafir to seed an acre when drilled in rows $31 / 2$ feet apart. 2 to 4 pounds of seed to the acre is all you will need. If you want to sow the seed broadcast or drill it with a drill for fodder, use 50 to 75 pounds per acre.

DWARF BLACKHULL WHITE KAFIRLb., 20c, postpaid; hy freight or express, lb., 10c; bu., 50 lbs., $\$ 2.50$.

PINK HULL WHITE KAFIR-The earliest type of Kafir. Lb., 20c, postpaid; by freight or express, lb., 10c; bu., $50 \mathrm{lbs}$., $\$ 2.50$.

STANDẢRD WHITE KAFIR-Lb., 15c, postpaid; by freight or express, lb., 10c; bu., 50 Ibs., $\$ 2.50$.

RED KAFIR-Grows taller than the white; stalks slender, juicy and very leafy. The seed is red and smaller than the white and yields much heavier. Lb., 20c, postpaid. By freight or express, lb., 10c; bu., 50 lbs., $\$ 3.00$. again, most planters will not use enough seed to the acre. The soil should be thoroughly prepared by deep breaking and thorough harrowing until a smooth hed is made, and the ground should be settled thoroughly before sowing. After sowing the seed, very little covering should be given with a brush or harrow that will cover it lightly. If the weather is likely to be dry, the ground should be pressed over the seed, so as to bring the seed in close contact with the soil to hold the moisture until the seed gets a good start.

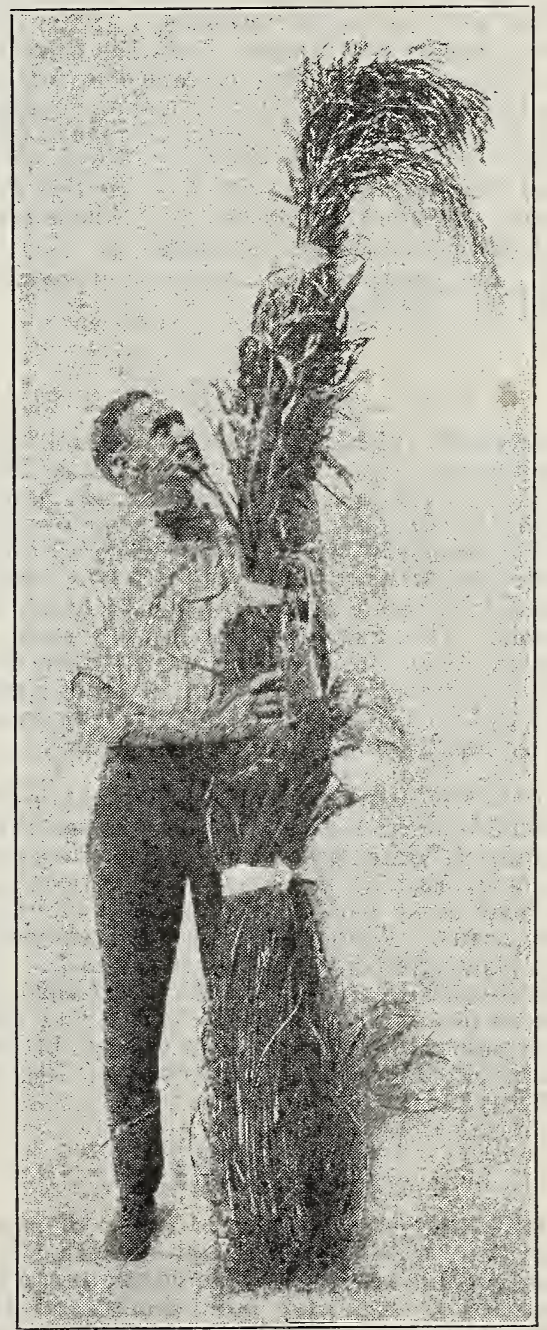

Sudan Grass 


\section{FIELD SEEDS}

\section{Darso}

DARSO-is low growing heavily foliaged, and has a large stalk which is usually tinged with red. It is remarkable for its uniformity in height and uniformity in shape and color of heads. The stalks are sweet and juicy, and chemical analysis of grain shows that the composition is very similar to that of Kafir. Darso matures earlier than Kafir, which fact has much to do with its drouth resistance. At the Oklahoma Experiment Station, Darso has been used as a safe feed crop during years of severe and continued drouths. Darso makes excellent silage, and can be used for grain, forage or silage crop. Worms do not take the Darso in the feld before harvesting as they do the other grain sorghums. Neither do chinch bugs damage Darso as they do Milo.

Lb., 20c, postpaid. By freight or express, lb., $10 \mathrm{c} ;$ bu., (50 lbs) $\$ 3.00$.

\section{Milos}

DWARF YELLOW MILO-A dwarf im. provement of the old Standard Yellow Milo. Grows 3 to 4 feet high, while the old variety grew 8 to 10 feet. Dwarf Milo is quite similar to the Standard Milo, but the heads all invariably bend over from the weight. It is not unusual for a head of Dwarf Milo to weigh one pound. The feeding value is the same as Yellow Milo. This variety seems to be more popular throughout the western plains of Kanses and Oklahoma Lb., 20c; postpaid. By freight or express lb., 10c; bu., (50 lbs) $\$ 2.50$.

DWARF WHITE MILO-Be certain the ground is warm before you plant the seed. The nature of White Milo Seed demands warm soil in order that it may make its development without a set back caused by cold nights or cold ground White Milo is a heavy grain yielder and plants grow from four to six feet high. The kernels of White Milo are soft and furnish excellent feed for all kinds of animals and fowls The grain may be fed whole or ground. Lb. 20c, postpaid. By freight or express $1 b .10 \mathrm{c}$, bu. (50 lbs) $\$ 2.50$.

\section{Hegari}

HEGARI-A new grain or forage crop similar to both White Kafir and Feterita. It is more desirable for grain than either, as the bad qualities of both have bcen eliminated. Feterita shells out pretty badly, and Hegari will not shell. Feterita is soft and pithy, while Hegari is solid and sound and with plenty of blades. Its dwarf habit of growth, 4 to 5 feet in height, and compact heads of large white grains make it rery attractive. Hegari also produces large crops of grain. The stems are rather sweet and horses and cattle eat the stalks fodder and grain if permittd to do so. lb., 25c, postpaid. By freight or express, lb., 10c; bu., $50 \mathrm{lbs}, \$ 3.50$.

\section{Feterita}

FETERITA-grows from 6 to 8 feet high The plant resembles Kafir but the stalks are much more slender. Feterita should be planted in rows three and one-half feet apart and the seed should be dropped from eight to fourteen inches apart in the row. When Feterita gets up abcut eight inches high, it branches out from four to ten sucker plants and each of these sucker plants grows up the same as the main plant. On account of this suckering habit of Feterita it should be planted thinner than Kafir or Milo. The first or main seed head ripens 15 to 30 days before the heads of the suckers are mature enough for grain. The grain is white like White $\mathrm{Kafir}$ and about twice the size. A splendid feed for poultry and other livestock. Feterita matures in from 80 to 90 days from date of planting. Feterita can be sown after wheat crop has been harvested, and in 80 to 85 days will turn out a yield of grain ranging from 15 to 40 bushels per acre, depending on the season. Feterita is a great drouth resister, and in this respect will withstand continued heat and drouth better than either Kafir or Milo.

Lb 25c postpaid. By freight or express, lb., $10 \mathrm{c}$; bu , (50 lbs) $\$ 300$

\section{Gentlemen :}

The Irish Grey watermelon seed I bought from you made more money for me than I anticipated, and next year I will plant more largely of this variety. I must ship my melon crop in order to make anything. I sold and shipped one car to a large retail store in one of the Central West cities and the day the Irish Grey melons were unloaded they telegraphed to load another car and ship immediately, and then ordered the third car. As you know, I planted the seed very late, and still, under this handicap my crop made a larger profit than neigh. bors received from sale of other varieties. Yours truly, M. T. Williams, Sept. 19, 1924. $\quad$ Medicine Lodge, Kans.

We urge early buying of all Garden Seeds. So many kinds are a short crop this season. 


\section{SORGHUM}

HONEY DRIP OR JAPANESE GANEOur grower describes this cane as follows:" This variety of cane is without doubt the best all: around cane for the Southern farmers. It is the very best syrup producer of all the varieties and is also a splendid forage crop for green feeding making excellent hay if sown in drills very thick and may be planted any time between April and August. It grows from ten to twelve feet high and is very prolific, sometimes producing 5 to 7 stalk, from one seed. Matures about the middle of August to October-owing to time of planting-but will keep green and stand, if desired until killed by frost, allowing the farmer to take his time to harvest for syrup. As a syrup producer, it has no equal, being exceedingly juicy and sweet, making from 200 to 400 gallons per acre, highly flavored. As a feed crop, it is the best the farmer can grow, on account of its immense amount of sugar, producing from two to three crops per season. One great advantage over some other varieties is, if the season is too dry for more than one crop to be raised, this first growth will not mature and fall down, but will stand until frost, retaining its soft, nutritious qualities. It has a large, open head, with bright red seed, and, if allowed to stand until late fall, each stalk will produce 7 to 8 heads, free from smut." For syrup, sow 10 pounds per acre. Lb., 25c, postpaid; by freight or express, lb., 20c; 20 lbs., $\$ 3.00$.

BLACK AMBER-90 days. the old original early variety grown almost exclusively for forage crop either alone or broadcasted with cow peas. Fodder quality. Lb., 20c; postpaid. By freight or express, lb., 15c; bu, $50 \mathrm{lbs}, \$ 2.50$.

RED AMBER-requires 90 to 105 days in which to mature seed crop. One of the most valuable kinds of sorghums for ensilage and is practically sourless when stacked out-doors. We recommend this variety to growers who want good forage or ensilage. Lb., 20c,postpaid. By freight or express, lb. 15c; bu. 50 lbs., $\$ 2.50$.

EARLY ORANGE-matures a grain crop in 110 to 120 days. It is later than either variety of the Ambers. Its stalks are heavier and shorter than either of the Ambers. Its forage quality is first class. Is very valuable for ensilage. One of the heaviest producers of ensilage of the entire sorghum family. Lb., 20c, postpaid. By freight or express, lb., 15c; bu., 50 lbs., $\$ 2.50$.

\section{OR GANE}

KANSAS ORANGE-Probably 5 to 10 days jater in maturing than early orange, more uniform in growth. Has the ability to stand storage out doors, retains its sweetness and palatability until late in the spring. Price 25c per lb.,postpaid by freight or express lb., 20c; bu., 50 lbs., $\$ 3.00$.

RED TOP or SUMAG-In our opinion this in the best variety for forage or dry hay. The stalks are much smaller than either of the Amber or Orange varieties. It requires 130 to 140 days to mature a seed crop. We do not recommend this variety for ensilage as strongly as we do the larger stalk varieties, but many of our customers say it makes very excellent ensilage. There is no better quality for forage than the Red Top. It will remain sweet and wholesome until late in May of the year following harvest. Lb., 25c; postpaid. By freight or express, lb., 20 c; bu., 50 lbs., $\$ 3.00$.

\section{SOURLESS GANE or African M i 11 e t-} is the favorite varicty in parts of Kansas and Oklahoma. Stalks of medium beight, sweet and does not sour during late winter,and retains its fine feeding quality until middle of May following harvest. We recommend it for light soils. Lb., 20c; postpaid. By freight or express, lb., 15c; bu., 50 lbs., $\$ 2.50$.

\section{BROOM CORN}

BROOM CORN-belongs to the same plant family as Cane, Kafir and Milo. It is divided in two groups, known as Standard and Dwarf. There are a good many names given to Broom Corn, which are used in localities where it is grown.

STANDARD-This variety grows from 7 to 12 feet high. It requires a different manner of gtthering the heads. The tall stalks are broken or tabled at a beight of about 3 to 5 feet from the ground and two rows are brought together in $\mathrm{V}$-shaped form so that the heads protrude just beyond the outside row or"table"as it is generally called. Lb., 25c; by frt. or express, lb., 20c.

DWARF-This variety grows $3 \frac{1}{2}$ to 6 feet in height and the head is partly enclosed in the sheath boot of the upper leaf and it is more convenient to pull the heads than the "table" way, Lb , 25c; postpaid By freight or express, lb. $15 \mathrm{c}$ ask for prices on larger quantities 


\section{The Millets}

TENNESSEE GOLDEN MILET-Golden millet makes a large-yielding and most nutritious hay crop quick-growing and easily cured. It requires, however to be seeded thickly-not less than 1 bushel per acre-and the crop should always be cut while in bloom before the seed hardens in the head. If the seed is allowed to form the stalks get hard and it does not make nearly as good quality hay, and at the same time it is more exhaustive to the land. It can be sown at any time from May first to the end of July. It matures its crop in from six to eight weeks after seeding.' Sowing Golden millet with cow peas for a hay crop seems to be increasing. Sown in this way it should be sown with some quick-maturing variety of cow peas, such as Whippoorwill or New Era, and it should be sown at the rate of $3 / 4$ bushel of millet and 1 bushel of peas to the acre. It is necessary when these crops are sown together to cut the crop at the time the millet is ready to cut regardless of the maturity of the cow peas; sown together this way, they make a much larger yield thas either crop alone, and cure up and make splendid nutritious feed. Our TennesseeGolden Millet is the best obtainable. Grows 4 to 5 feet tall with heads 5 to 7 inches long. Write for prices stating quantity.

WHITE WONDER MILLET-The seed of this wonderful millet was brought to this country from China by a Russian soldier, who served in the Japan-Russian war. He recognized the many desirable qualities of this millet, and brought a little of the seed to this country. It has been raised in Western Kansas for several years. The most striking feature of White Wonder millet is the size of the heads. The heads of this variety will run from 8 up to 18 inches, and a single head will sometimes have as many as 15,000 seeds. The yield of White Wonder millet is very heavy, this variety will yield fully half as much again as Golden millet and some growers state that it will outyield other millets 3 to 1 . Another very desirable feature is its earliness. White Wonder millet is much earlier than Golden millet and is almost as early as Siberian millet. The foliage is very heavy and the leaves broad. It produces an immense amount of excellent fodder, which cures very readilv. On account of its earliness, the immense yield of both grain and fodder, and the very vigorous growth, which leaves the ground clean, White Wonder millet will be in big demand, and we urge you to make a liberal planting this year, and get in on the ground floor. Lb. 25c, postpaid; by freight or express, lb. $15 \mathrm{c} ; 10$ lbs., $\$ 1.00$.

GERMAN MILLET-Grows very rank, generally 3 to 4 feet high. Far superior to Common millet, both in quality and yield, but about two weeks later. Drouth resisting and 3 to 4 tons per acre. Sow 35 to 50 lbs per acre. Price will be quoted on request.
SIBERIAN MILLET-Regarded as one of the best varieties for general cultivation in Western states. Matures about the same as Common Millet. Its abundant growth, leafy character of stalks and drouth resistant qualities have brought it into favor in the Northwest. Will quote prices on request.

JAPANESE MILLET OR BILLION DOLLAR GRASS-Well adapted to wet or low grounds. Produces large amounts of hay, 5 to 8 tons per acre. Will produce hay crop in 6 to 10 weeks; 4 to 7 feet high. Will quote prices on request.

\section{Root Crops for Stock Feeding}

MANGEL WURZELS-The value of root crops for stock-feeding during the winter months is being more recognized. Foremost among these are the mangel wurzels and the sugar beets, of which an enormous crop may be raised at a trifling cost per acre. The roots, if fed to the cows, will greatly increase the flow of milk; they will improve the general condition and health of all animals to which they are fed, besides saving hay. They should be planted in rows 3 feet apart in very rich soil; 5 to 6 pounds of seed will plant an acre.

MAMMOTH LONG RED-The roots of this variety grow to a larger size than those of the other sorts. They are well formed, with flesh of a hlood-red color. Very nutritious. Pkt., 5c; oz., 10c; 1/4 lb., 20c; lb., 55c, postpaid; by freight or express, lb., 50c; 10 lbs., $\$ 4.50$.

GOLDEN TANKARD-The most nutritious variety. Pkt., 5c; oz., 10c; $1 / 4 \mathrm{lb}$., 20c; lb., $55 \mathrm{c}$; postpəid; by freight or express.. lb., $50 \mathrm{c}$; 10 lbs., $\$ 4.50$.

GIANT HALF SUGAR MANGEL-This is a hybrid, or cross between the Mammoth Long Red and Sugar Beet, and in feeding value is far superior to either. As heavy a cropper as the mangels, sweeter, and much relished by cattle and hogs. Pkt., 5c; oz., 10c; $1 / 4$ lb., 20c; lb., 55c, postpaid; by freight or express, lb., $50 \mathrm{c} ; 10 \mathrm{lbs}$., $\$ 4.50$.

\section{Sugar Beets}

\section{VILMORIN'S IMPROVED-The richest}

sort in cultivation, containing, under favorable conditions, as high as 18 percent of sugar. The roots grow below the surface of the ground, are small to medium size, and yield several tons per acre. Fed to cows, they will improve the quantity of millk wonderfully. Lb., 70c; postpaid; by freight or express, lb., 60c; 10 lbs., $\$ 5.00$.

KLEIN WANZLEBEN-The roots are a little larger than most varieties, as well as hardier and more easily grown. Lb., 55c, postpaid; by freight or express, lb., $50 \mathrm{c} ; 10 \mathrm{lbs}$., $\$ 4.50$. 


\section{Supply Department}

\section{CHAMPION DOG FOODS}

Are Clean Enough for Human Consumption Pure Cod Liver Oil is used in Champion Biscuits.

Champion Dog Biscuit is composed of clean, sweet meats-twenty-five per cent more than in any other dog food-and the choicest of cereals and ground grains; all perfectly blended in the proportions best suited to the needs of the dog. Being heavy with protein - the real esential basis of all dog foods-Champion Dog Biscuit is most nourishing. It is truly "The Balanced Ration" in every sense.

Champion Dog Biscuit is intended as a regular and steady diet. Being a balanced ration, it supplies food elements necessary to produce smooth, glossy coats, regular habits and general good condition. Champion Dog Biscuit builds bone and sinew, imparts strength and stamina.

Also Special Biscuits for puppies, and Kibbled Dog Food.

GHAMPION DOG FOODS Per Lb. 25 Lbs.

Puppy Biscuit .\$0 15

$\$ 300$

15300 $\begin{array}{lll}\text { Kibbled Dog Food .. } & \mathbf{1 5} & \mathbf{3} \mathbf{0 0} \\ \text { Dog Biscuit ........... } & \mathbf{1 5} & \mathbf{2} 85\end{array}$ $\begin{array}{lll}\text { Kibbled Dog Food .. } & \mathbf{1 5} & \mathbf{3} \mathbf{0 0} \\ \text { Dog Biscuit ........... } & \mathbf{1 5} & \mathbf{2} 85\end{array}$

$100 \mathrm{Lbs}$. $\$ 1000$ 1000 1000 900

Ask for prices in large quantities.

\section{Perfection Dog Food}

Per 100 Pounds..

\section{Spratt's \\ Widely Used}

Per Lb. 25 Lbs. 100 Lbs.

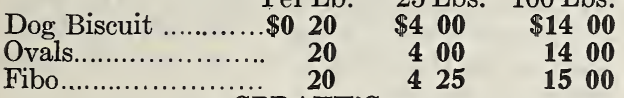

\section{The Well Known Remedies}

Per Package

Worm Capsules. $\$ 060$

Digestive Tablets.

60

Distemper Tablets.

60

Tonic \& Condition...

Cough Tablets.

Diarrhoea Tablets

Ear Canker Ointment............................

Eczema Tablets.

Flea Powder.

Flea Soap.

\section{GANARY BIRDS}

Our prices are always in accord with the quality; that is why we say that if a bird does not sing, you can exchange it. Write us about what you want.

You may be sure that in ordering from us you will get the best the market affords as our Bird Department buys only the very best. For the present the following prices are quoted F.O.B. Wichita, subject to stock being unsold.
Imported St. Andreasberg Roller

singers................................. \$15 00

Each

Imported Hartz Mountain singers.......... 1000

Native Hartz Mountain singers............... 700

Native Hartz Mountain Females............. 200

Imported St. Andreasberg Females ......... 5

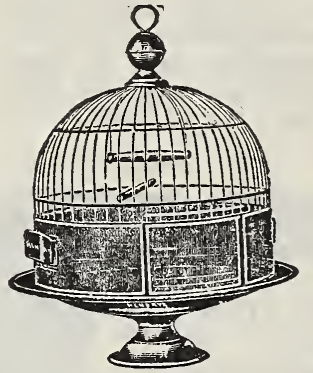

No. 275

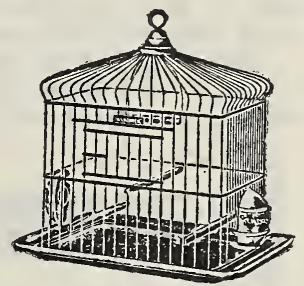

\section{CAGES}

We carry a fine line of Hendryx Cages and stands. Nothing better. Space permits listing a limited number only. We illustrate only two cages. We have as many kinds of cages as there are kinds of birds.

Round Brass Cages, No. 274 ............. \$4 35

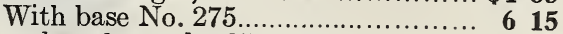

and seed guards, No. $276 \ldots \ldots \ldots \ldots \ldots . \quad 7 \quad 35$

Round Brass Cages No. $1274 \ldots \ldots \ldots \ldots \ldots \ldots \ldots .4 \quad 15$

With flat bottom, No. $1275 \ldots \ldots \ldots \ldots \ldots . .535$

and seed guard No. $1276 \ldots \ldots \ldots \ldots \ldots \ldots .6 \%$

Square Japanned No. $159 \ldots \ldots \ldots \ldots \ldots \ldots \ldots, 2 \quad 15$

Without seed guard No. $161 \ldots \ldots \ldots \ldots \ldots . . .2 \%$

Without seed guard No. 163.............. 315

Oblong Japanned No. 166 ...................... 215

Without seed guard No. $167 \ldots \ldots \ldots \ldots \ldots . . . .270$

Without seed guard No. $168 \ldots \ldots \ldots \ldots \ldots . .315$

Also round white ivory and white striped green cages same sizes as round brass cages at 25 cents higher price than the brass.

\section{BIRD SUPPLIES}

Seed Cups, No. 1 Flint Glass, Each......... \$0 20

No. 2 Opal Glass, Each........................ 25

75 Brass Bird Cage Springs, Each................. 35

60 Bird Bath, Opal......................... 25

40 Perfection Mixed Bird Seed, Per Lb......... 20

25 Canary Seed, Per Lb.......................... $\quad 20$

Hemp Seed, Per Lb.......................... 20

Rape Seed, Per Lb........................... 20

Sunflower Seed, Per Lb....................... 20

Cuttlefish Bone, Each...................... 10

Bird Manna, Each...15c., Doz. Pkgs......... 160

If seeds are wanted by mail, add postage.

Parcel Post Charges on remedies in small quantities, minimum of $10 \mathrm{c}$; larger quantities at regular zone rates packing usually requires an additional pound. 
HORN SEED SOWER-Sectional Tube Style. Has a heavy canvas bag with strap to go over shoulder. The tube is in three sections and of a graduating diameter. Length is 30 inches. Full directions with each machine. Price $\$ 1.25$ each.

CAHOON SEEDER-Easily the leader in its class. Strongly built; sows wheat, oats, barley, and all grain and grass seeds five times faster than by hand. Price, each $\$ 5.00$.

THE GYGLONE SEEDER-Sows all kinds of grain and seeds perfectly-oats, cow peas, millet, etc. Each, $\$ 2.50$.

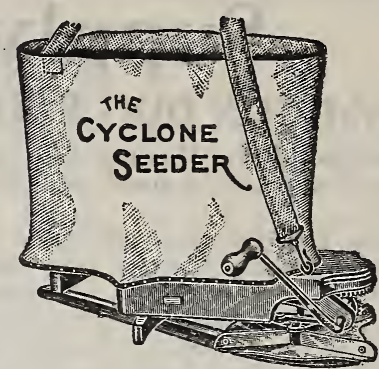

HUDSON JUNIOR SPRAYER

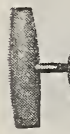

CONTINUOUS SPRAYER-This sprayer is popular because it delivers a fine, even spray continuously. All working parts are brass. Tank is heavy tin. Price, $\$ 1.00$ each.

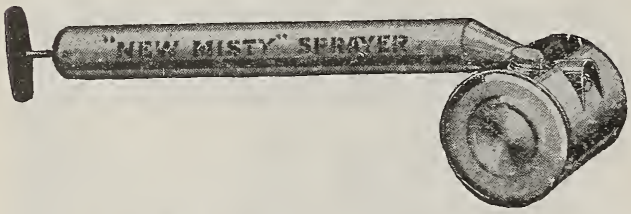

THE NEW MISTY SPRAYER-A general purpose sprayer for farm, stable or garden uses; handles fly oils, bug poisons, and disinfectants; has large, powerful pump; lined can screw; made of heavy tin: holds 1 quart. Price, 60c.

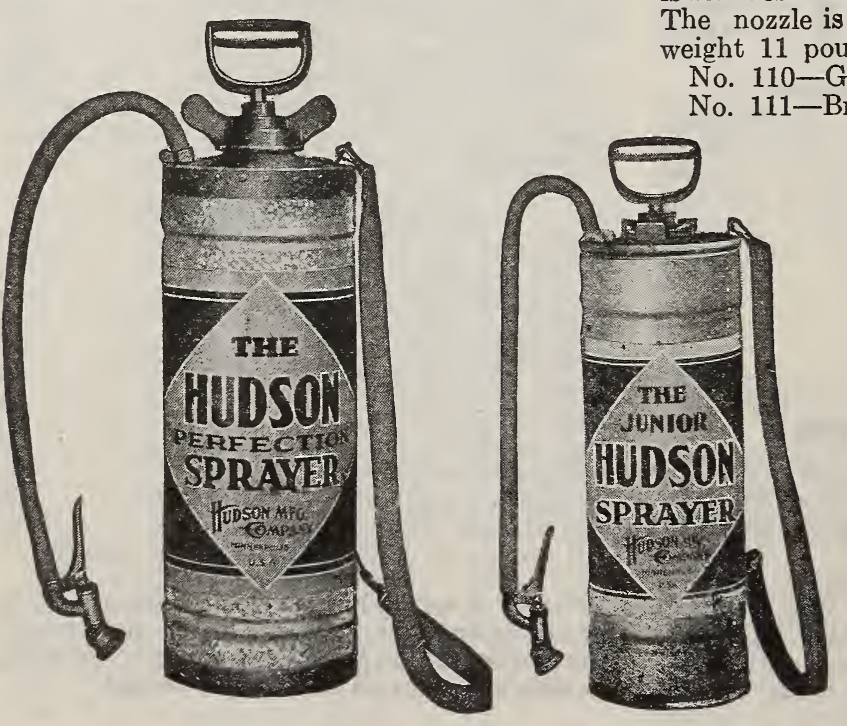

The Junior Sprayer is made for the man who needs a high pressure compressed air sprayer smaller than the Perfection. Tank capacity about $2 \frac{1}{2}$ gallons. Nozzle is the same as used on our Perfection. Shipping weight $8 \mathrm{lbs}$ No. 140-Galvanized Tank $\$ 5.50$ each No. 141-Brass Tank \$8.00 each

PERFEGTION SPRAYER-For work of any kind requiring a high pressure compressed air sprayer the Perfection is supreme. It can be used around the house and yard, in the barnyard and outhouses, on truck farms, in vineyards, potato, onion and melon fields and in all sizes of orchards. Will work worders for the farmer in treating his cattle, hogs, poultry and sheep, etc.

The tank is built like a steam boiler. All seams are riveted and soldered to withstand the high pressure it develops. $7 \frac{1}{2}$ inches in diameter, 20 inches high; capacity 4 gallons. The pump is seamless brass tubing. The valve is brass. The nozzle is automatic in action. Shipping eight 11 pounds.

No. 110-Galvanized Tank,\$6. 5 each.

No. 111-Brass Tank, $\$ 9.50$ each.

POWDER SPRAYER-This pattern is very popular in the home for applying Roach powder and similar preparations Price $45 \mathrm{c}$ each.

It is necessary to be prepared to fight any and all kinds of insects, blight, fungus growths, blotch, bugs, vermin and other destructive pests. This may be accomplished by possessing a sprayer capable of performing the work you find it necessary to do. We sell many dozen Standard spray pumps each season, and the demand for Compressed air Sprayers is increasing each season. 


\section{HUDSON BARREL PUMP}

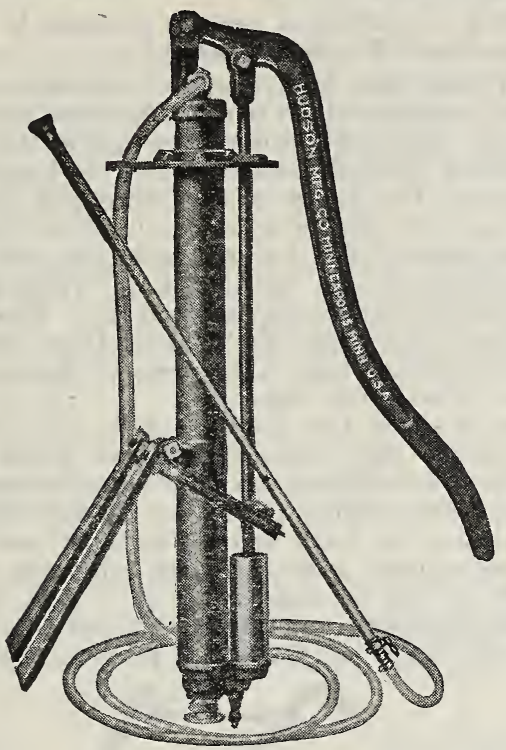

This pump will meet every requirement of a perpendicular barrel pump. It is powerful, light and durable, and will maintain a working pressure of $200 \mathrm{lbs}$. Has capacity for two lines of hose if desired.

Cylinder, seamless brass tubing, $13 / 4$ in.diameter, 7 in. long. Air chamber, high carbon steel 2 in. diameter, 30 in. long. Valves, bronze balls, easily removed for cleaning. Agitator, swinging type, driven with each stroke of the handle. Discharge equipment, $12 \frac{1}{2} \mathrm{ft}$. of $1 / 2$ inch spray hose and Ideal angle spray nozzle. No. 4A Pump as above, price $\$ 14.50$.

\section{EUREKA SPRAY OUTFITS}

Develops working pressure of 200 pounds and is equipped with a large air pressure tank to maintain high pressure and steady discharge. Our regular No. 4 Pump is used, mounted on side of barrel tank. 50 gallon. Pressure tank, 10 inches in diameter and 24 inches long. Boiler steel with welded seams; tested under pressure of $275 \mathrm{lbs}$. Wheels, 30 inches diameter. 2 inch tires. Frame, steel tubing, handle of same material. Discharge equipment, $12 \frac{1}{2}$ feet, $1 / 2$ inch spray hose, and 8 foot iron pipe extension angle. Ideal spray nozzle and leakless shutoff valve. Weight, securely crated, $270 \mathrm{lbs}$. No. $2 \mathrm{E}$, Price $\$ 47.50$.

\section{STANDARD SPRAY PUMP}

The Standard is made entirely of brass. No Leather Packings. No Iron Castings to Rust or Decay. Nothing to get out of order. Its plan of operation is different from other types of spraying apparatus, since the hose is used on the suction end instead of the discharge end. This makes it possible to use the pump with a bucket, barrel, tank or knapsack, depending upon the number of trees or the kind of spraying to be done For bucket use a $31 / 2$-foot length of hose is supplied. To use it with barrel or tank for a large orchard, a longer hose up to 25 or 30 feet is desirable. For spraying young or scattered trees or truck crops such as potatoes, tobacco, etc., the knapsack and short extensions are used. With these attachments the Standard will spray potatoes one row at a time at the rate of an acre an bour or better. The Standard is provided with a set of three nozzles. The Standard with $3 \frac{1}{2}$ feet hose and full set of nozzles, $\$ 5.00$. Knapsack attachments, $\$ 3.00$.

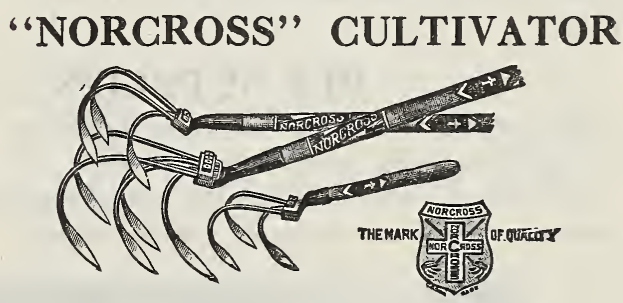

Will cultivate closer to plants without injuring them than any other type of implement known, leaving the soil level, loose and untrampled. The sharp, tapering shovels enter the ground easily and are so arranged, one with another, as to literally tear up every inch of soil from one to five inches deep.

Three sizes and prices: No. 55, 5-prong, $4 \mathrm{ft}$. handle, wt. 3 lbs. each $\$ 1.25$. No 33, 3-prong, $4 \mathrm{ft}$. handle, wt. 2 lbs., each 85c. No.11"Midget," 9-inch handle, wt. 12 ounces, price 50c. (Midget by Parcel post, prepaid for 60c.) 


\section{Hudson Drill Seeder and Cultivator}

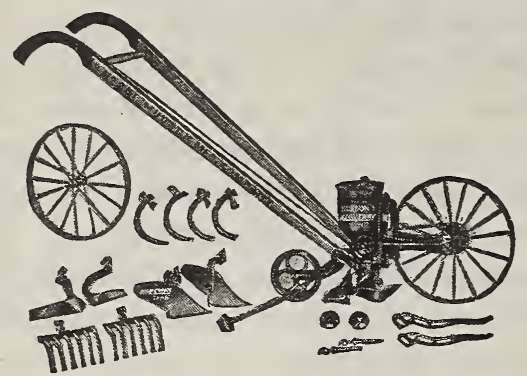

The seed regulator is now made entirely of brass with openings die cut instead of being cast or moulded. As a result it can be regulated perfectly. The seed flow adjustment is the heart and soul of a seeder for if the seed is not dropped uniformly, the crop will be irregular and poor. It will sow any seed from beans down to the smallest garden variety, and is a practical combination which can be changed in a moment from

\section{GARDEN PLOWS}

The high wheel garden plow is a universal favorite with the truck farmer or gardener where the work is sufficient to justify separate machines for seeding and cultivating. It has all the equipment for plowing and hilling, raking and cultivating either wide and shallow or narrow and deep. 24 inch high wheel is used which makes traction very easy. No. 242, each, $\$ 4.65$.

\section{BEE SUPPLIES}

Bee-keeping is a most desirable pursuit for both pleasure and profit by either man, woman or child.

We carry a complete line of Bee Supplies and issue a separate eatalogue, which we will gladly mail on request. sowing in continuous rows to dropping in hills spaced from 4 to 24 inches apart.

A brush force feed of selected bristles is used, and is guaranteed not to injure the most delicate seeds. The seed flow is in plain sight so that the operator can tell instantly when the hopper is empty. The furrow opening shoe and furrow are adjustable for depth up to 2 inches The handles have a plow handle grip, and are adjustable to suit the operator. Wheel is 16 inches in diameter with a broad tire. Frame is eable iron with tubular arch. Hoes, shovels and plows are hich grade steel; all shanks are made of malleable iron.

As a seeder this machine opens the furrow drops the seed, closes the furrow, packs the carth and marks the next row all in one operation. The seeding parts can be detached by removing two bolts, and the machine then becomes a single or double wheel cultivator, rake plow or hoe as desired. It is a neat, wellfinished machine, and will give entire satisfaction. No. 201 Seeder and Cultivator, price each $\$ 15.00$.

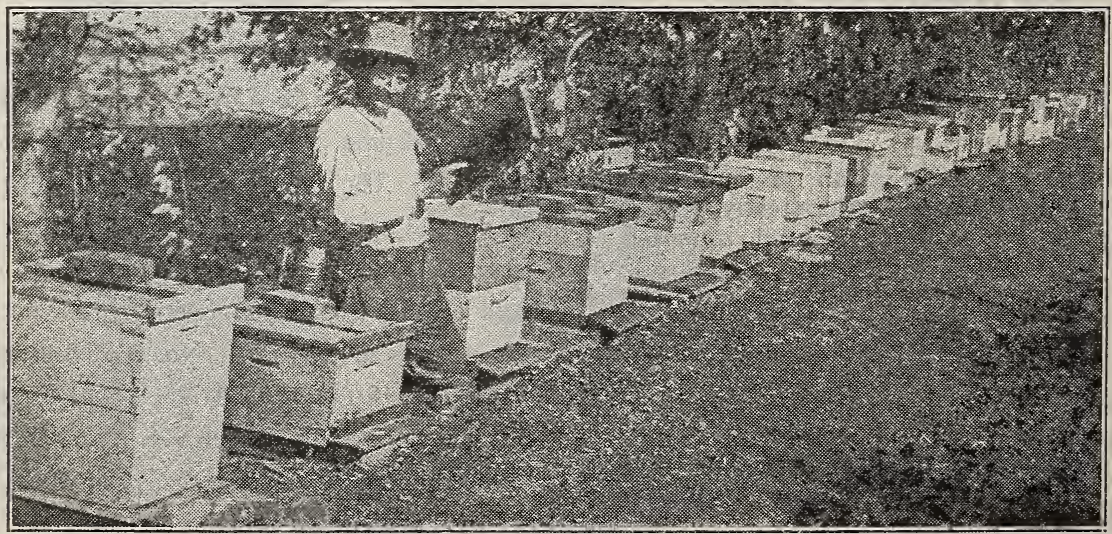




\section{Poultry}

PERFEGTION BRAND SGRATCH FOODFor laying hens; keeps them in good health the year around. Produces good results. Our Poultry Food is made of good, sound grains and seeds, all cleaned and screened before mixing, and is without dust, meal, or waste of any kind. Market prices.

\section{PERFEGTION BRAND GHICK FOOD-} Chicks properly started on good, wholesome food are the ones that reach maturity. Perfection Chick Food is the right food for chicks, comprising small grains, grit, charcoal, and beef scrops. Market prices.

\section{PERFECTION BRAND LAYING MASH-} An excellent egg-producer; strong in egg-making qualities; nothing like it to make hens lay in winter. Market prices.

GROUND BEEF SCRAPS-Feed three times a week at the rate of about a handful to every three birds in the morning meal of hot food, or keep in a hopper before the fowls, allowing them free access all the time.

Lb., 10c; 25 lbs., $\$ 1.75 ; 50$ lbs., $\$ 3.00 ; 100$ lbs., $\$ 5.00$.

DARLING'S MEAT CRISPS-A clean, wholesome meat concentrate for poultry; $75 \%$ protein guaranteed. Per sack of $25 \mathrm{lbs}$., \$2.50.

FINE GROUND BONE - For mixing once a day with soft food, this is unsurpassed. Lb., $10 \mathrm{c} ; 10 \mathrm{lbs} ., 75 \mathrm{c} ; 100 \mathrm{lbs}$., $\$ 4.75$.

CRACKED POULTRY BONE-Made from fresh, pure, clean bones, and it should be fed to the poultry daily-about one handful to every five fowls, like grain or any other food. Lb., 10 c; 10 lbs., 75c; 100 lbs., $\$ 4.75$.

PERFEGTION GRUSHED OYSTER SHELL - To a large extent, will supply the necessary material for grinding their food and at the same time the lime for egg shells. Chemical analysis, together with the reports from experienced poultry men, show that ordinary grain and green food supplied to the laying hens do not contain enough lime for egg shells. It requires several times as much lime as is ordinarily fed, if good, strong egg shells are to be produced. Crushed oyster shells will supply this lime, if kept continually before the fowls, trusting them to eat the amount necessary. The judgement of fowls can be relied upon in this respect. $50 \mathrm{lbs}$., 75c; $100 \mathrm{lbs}$., $\$ 1.25$.

\section{PERFECTION BRAND GHARCOAL-}

Specially prepared for poultry. Feeding charcoal purifies the blood, prevents disease, and is a sure cure for sour crop, diarrheoa, etc. Put up in two grades, fine granulated, for use in mash mixtures, and coarse, for hopper feeding. Lb., 10c 25 lbs., $\$ 2.00$.

\section{Foods}

\section{Conkey's Buttermilk Starting Food}

\section{The Original}

\section{Makes Husky Chicks}

A ready prepared feed for baby chicks and all self-feeding young fowls. Composed of buttermilk, pinhead oatmeal, a special wheat middlings whole cornmeal, corn feed meal and granulated bone. Contains all elements needed for safely starting baby chicks, ducklings, goslings, noults, pheasants, quails, grouse, etc.

\section{FEED IT FIRST 8 WEEKS}

Conkey's is all the chicks need the first eight weeks except greens, charcoal, grit, clean water, and some fine scratch grains in the litter for exercise. Give grit and water from the start. During the second week add green stuff and in the fourth week finely cracked chick grains, like CONKEY'S CHICK GRAINS. Write for prices.

Conkey's White Diarrhea Remedy will prevent the most fatal of all diseases of young chicks, 60c. Roup remedy 60c. Cholera remedy 60 c. Add $5 \mathrm{c}$ for postage.

\section{Quisenberry Quality Butter- milk Starting Food.}

The first feed given your chicks should be this marvelous Buttermilk Starting Food. It changes puny, weak chicks into husky broilers and early layers. Grows two-pound broilers quicker than any other feed. Almost half of every hatch die each year because people insist on feeding little chicks indigestible grains and worthless mashes.

It's made from pure dried butter-milk, oat flour, high grade meat scraps, bone meal and the choicest ingredients which contain just the right amount of vitamines and food elements mixed in the right proportions to insure the best results.

If you start your chicks right, the rest is easy. The first eight weeks is the most critical time in the life of any chick. Don't attempt to feed your baby chicks the same feed that you would use for growing stock or laying hens any more than you would think of feeding a human baby bacon, cornbread and beans. A baby chick grows thirty times as fast and its digestive organs are therefore more delicate and work more rapidly than the human baby's; therefore; save loss by starting your chicks on the right kind of food.

Ask for the lowest price when in the market for any of our Poultry Foods. 


\section{Poultry Supplies}

GHAMPION LEG BANDS-The oldest and most popular band on the market. The band is made in one piece in two sizes, adjustable to to fit any fowl. They will stay where you put them. Held by double lock, it is impossible for them to lose off. Made of best quality aluminum. Price, postpaid, 12 for 15c; 25 for 25c; 50 for $40 \mathrm{c} ; 100$ for $75 c$.

ASSORTED COLORED GELLULOID LEG BANDS-Doz., 15c; 50 for 50c; 100 for $85 \mathrm{c}$.

VICTOR BANDS-In colors with large printed numbers. 55c per dozen; $\$ 4.00$ per 100 .

\section{Money Back Poultry Punch}

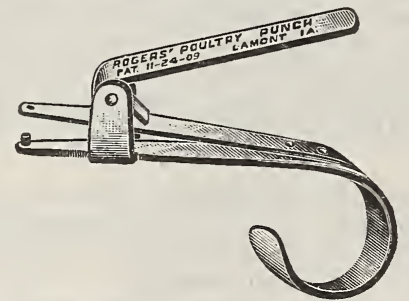

The cut is two-thirds size of punch.

The only guaranteed chick marker on the market. It hangs handily when marking the chicks so that the operator can readily see what he is doing. Price, postpaid, 40c.

PETTY'S PERFEGT POULTRY PUNCH -All steel nickle plated. Punches clean; hole right size; will not bruise foot. Price, 25c, postpaid.

CHINA NEST EGGS-With these eggs there is no danger of getting stale eggs mixed with the fresh ones, nor the hens eating them and acquiring the habit of eating eggs. 5c each, 12 for $50 \mathrm{c}$.

ANTI-LIGE NEST EGGS-A standard-size nest egg and lice-killer combined. Rids laying hens of lice and mites. Inexpensive to use. 10c each; 80c per dozen.

EGG TESTERS-Each $25 \mathrm{c}$.

AUTOMATIC FOUNTAIN AND GHIGKEN FEEDER - (Patent applied for). This appliance for chicks feeds, water, grain, grit etc.,automatically. It is an absolutely sanitary fountain made to fit any half-gallon, quart, or pint Mason jar. We do not furnish the jars. Price $15 \mathrm{c}$, each; $\$ 1.60$ dozen. Shipping weight, 6 ounces each.

\section{Ask for Poultry Supply Catalogue.}
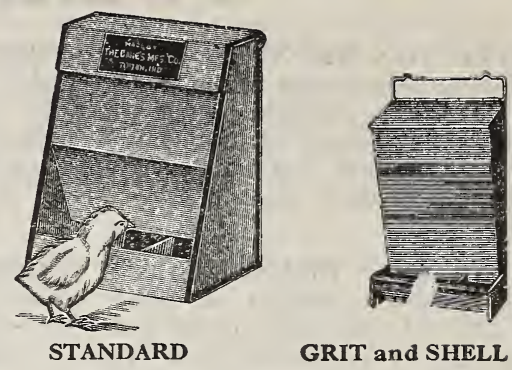

GRIT and SHELL BOX

GHICK GRIT AND SHELL BOX-Growing chicks should have grit, oyster shell, and - charcoal always before them; and for this purpose our Chick Grit and Shell Box is indispensable.

It is made of galvanized steel, with three compartments. Height, $71 / 2$ inches; width, 6 inches, depth (front to hack), 4 inches at bottom and 2 inches at top. Price, 75c. Shipping weight, 2 pounds. Large size for growt fowls, \$1.10. Shipping weight, 4 pounds.

STANDARD GRIT AND SHELL BOXThis grit and shell box has slanting front, inclined top and round bottom to trough. For large fowls, we recommend the three-compartment hopper described above. Price, \$1.25. Shipping weight, 2 pounds each.

\section{Round Baby Ghick Feeders}

The most popular baby chick feeder on the market. The top fits snugly, yet it can be easily taken apart for cleaning and filling. Made in two sizes.

No. 11-Diameter 6 inches, with 8 holes, $20 \mathrm{c}$ each.

No. 12-Diameter $81 / 4$ inches, with 12 holes, $35 \mathrm{c}$ each.

STONEWARE DRINKING FOUNTAINS1-Gallon size, each 50c. 2-Gallon size, each 85c.

\section{DON SUNG}

Don Sung (Chinese for egg laying) is a scientific tonic which improves the hen's health makes her stronger and more active and tones up the egg laying organs.

Don Sung is easily given in the feed, and costs nothing to try. It is used by thousands of successful poultry raisers the world over.

Regular size, 50c. Large size, $\$ 1.00$; holds 3 times the $50 \mathrm{c}$ size. Special size, $\$ 5.00$; bolds 6 times the $\$ 1.00$ size. 


\section{POULTRY SUPPLIES-Continued}

\section{LITTLE PUTNAM STOVE}

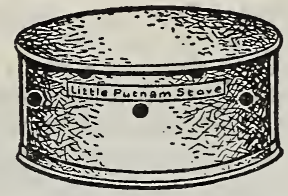

The Putnam Stove is nine inches in diameter and four inches high. The oil tank holds three pints of oil and burns three to four weeks without refilling or any other attention. The wick never needs trimming. The Little Putnam Stove is used under the drinking vessel in the poultry house to keep the water from freezing during the winter months. It is also used as the heat element in the Putnam Home Made Oat Sprouter. It is absolutely fire safe and non-explosive. If it is tipped over it will go out. If it becomes buried in the litter it will go out.

The stove has to be filled but a few times during the entire winter and never requires trimming. Complete plans for making Oat Sprouter at a total cost of $\$ 2.49$ furnished with each stove.

Little Putnam Stove, each $\$ 2.50$ postpaid.

\section{BROODER HEATER}

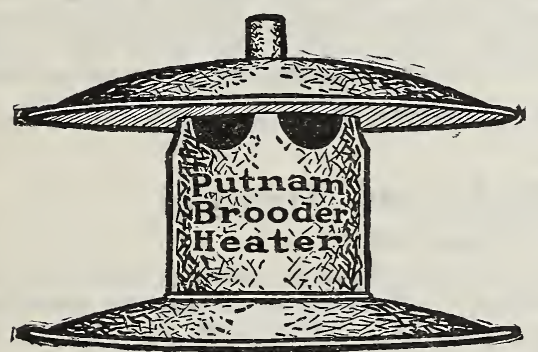

This fire-safe Putnam Brooder Heater is the heart of the Putnam Home Made Brooder. It requires tending only once a week and can be relied upon to deliver a regular supply of heat. Complete plans for making a practical Brooder with each Brooder Heater. Price, $\$ 4.75$, postpaid.

\section{RAT NIP}

\section{Kills Rats Every Time}

Rat Nip has no parallel for successfully destroying rats. It has an attraction for rats that they cannot resist. The odor and composition of Rat Nip is such that rats will scent it far away and when found they eat it ravenously. $2 \frac{1}{2} \mathrm{oz}$. package, 30c. As this is poison it cannot be sent by mail.

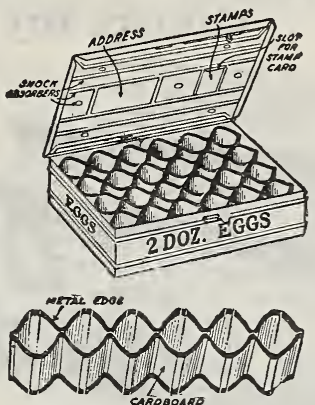

SELL EGGS BY MAIL

to Your Friends Shipped in Aluminized METAL EGG CRATES

Indestructible; pays for itself in a few shipments; lasts for years; makes interchangeable shipping easy. Buy yours now and realize more money for your eggs. Your friends want them.

The Metal Egg Filler is a wonder. A new invention and cannot be beat for safely carrying eggs by mail. Light in weight but strong.

2-dozen egg size, Each, \$1.50. 3-dozen egg size, $\$ 1.75$. 4-dozen egg size, $\$ 2.00$. 6 dozen egg size, $\$ 2.50$. Add postage for 4 pounds to the price of each box.

\section{Farmers Friend Wooden Egg Carrier}

Is complete with fillers. Great for shipping eggs by parcel post or express or delivering eggs to market. Adjustable Cover, Patent Combination Cover fastener and lifter combined. 12-dozen size, price, $\$ 1.25$.

\section{The Eyrie}

A box that is self-locking cannot be tampered with, impossible to pilfer after it is filled. Placing the handle in socket locks the box. You can stand on it after locked without damage to contents.

Prices: No.1-1 setting, each 40c., per dozen, $\$ 4.25$.

\section{The Sefton}

Two layers corrugated paper to protect the eggs from damage.

1 dozen size, each 15c; per dozen, $\$ 1.50$.

4 dozen size, each $35 \mathrm{c}$; per dozen, $\$ 3.75$.

RAX

You can surely and quickly put an end to all the rats and mice about your place. They will die outdoors. An important feature is that RAX is not a poison. It is harmless to human beings, house pets, chickens and other domestic animals, but deadly to rats, mice, gophers, field mice, and all members of the rodent family. Its effect is that sometimes entire droves in a locality. are completely wiped out. They do not die in buildings but in the open, where they go in search of air and water. It is simple to use and does the work effectively and with absolute safety. Price $75 \mathrm{c}$ a bottle, postpaid. 


\section{POULTRY SUPPLIES-Continued Cymaco Dry Mash Feeder}

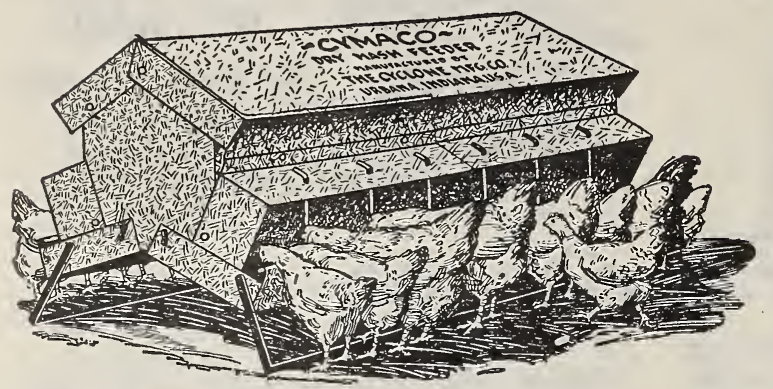

Cymaco Feeders are adjustable. On each end are two thumb screws by which the flow of feed may be regula. ted to accommodate either fine or coarse feed from hopper to trough.

Feeding from both sides, the $\mathrm{Cy}$ maco accommodates twice the number of hens at the same time as the ordinary hopper feeder.

Suspended from the dirt and weather guards on either side of the feeder, are agitator rods which pass through the lower part of the hopper, with the

The illustration is of the 24-inch Cymaco Feeder. Their superiority is eviderced by thousands of poultrymen and farmers using them.

The first outstanding feature of Cymaco Feeders is their sturdy and practical construction. They are built of galvanized steel with enameled steel legs, which hold the feeder away from the ground and dirt. They may be set anywhere in poultryhouse or yard, and are weatherproof. ends extending into the feed, so that fowls feeding, move the agitator and stir the feed, thus keeping it from clogging.

No. 12-12 inches long, with two feet feeding capacity; holds one-half bushel. Shipping weight, 11 pounds. Price, $\$ 2.50$.

No. 24-24 inches long, with four feet feeding capacity; holds one bushel. Shipping weight19 pounds. Price, $\$ 3.50$.

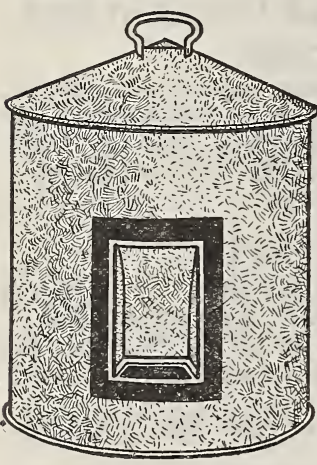

\section{Royal Thermic Fountain}

Royal Thermic Fountains are made of the best quality of galvanized iron with double walls and packed with an efficient insulating material; keeps the water warm in winter and cool in summer; insulation is completely 2 round the inside tank. Extra heavy malleable handle, well fastened, for carrying. Special reinforced bottom $3 / 4$ inch off the ground. Extra wide and deep pockets. Inset pocket and cone top, keeps water in drinking pocket clean. Well crated and absolutely guaranteed.

No. 2-2 gal. size; packed one to crate, shipping weight, 18 lbs., Each, $\$ 3.50$; postpaid, $\$ 4.00$.

\section{Royal Ghick Feed Troughs}

\section{Three Sizes}

These Feed Troughs can be used for chicks or growing stock and are used abundantly under brooders for the feeding of starting feeds and

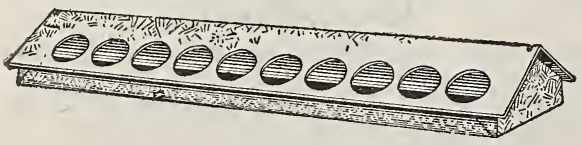

Length 12 inches, 14 feeding holes, Each 25c, Postpaid, 35c.

Length 18 inches, 22 feeding holes, Each 35c, Postpaid, 45c.

Length 24 inches, 30 feeding holes, Price $45 \mathrm{c}$, Postpaid, 55c. chick feeds of any kind. They are made of the best quality prime sheets galvanized iron accurately stamped with dies. Two heavy beads are placed in the bottom of the pans and one up each end over the tip that catches the top, which strengthens the trough considerably and makes it as substantial as any trough made. Some users prefer these to the slide top trough, as they eliminate the possibility of the feed sliding off. The holes are punched round close to the bottom, without rough edges, so that the chicks can feed readily without having to attempt to get in the feeder.

\section{Royal Mason Jar Fount}

Made of extra heavy galvanized iron. No solder used. Verv substantial pan with heavy rolled edge; electric welded center; can be used for chick feed as well as water. We do not furnish the glass jars. Each, 15c; postpaid, 20c., dozen, $\$ 1.15$, postpaid, $\$ 1.30$. 


\section{POULTRY SUPPLIES-Con tinued}

\section{TESTED THERMOMETERS}

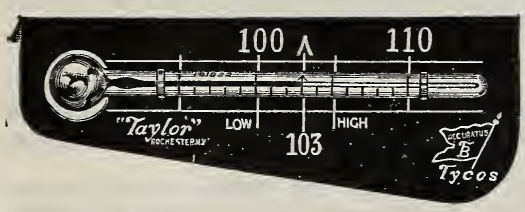

The best incubator or brooder is useless unless the thermometer used therein is accurate. Hundreds of hatches in incubators fail because of inferior thermometers. A large number of chickens are killed in brooders owing to defective or worthless thermometers. The thermometers listed herein are manufactured especially for us, and are thoroughly tested and seasoned before they are shipped.

Tycos Certified Incubator Thermometer Engraved tube, every fifth line and figure stamped on the scale. Each one accompanied by maker's certificate of accuracy. Each $\$ 1.25$.
Taylor Brothers Incubator Thermometers, 75c each, postpaid, 90c.

Taylor Brotbers Brooder Thermometers, 65c each, postpaid 75c.

\section{UP-TO-DATE IMPROVED BLUE FLAME HOVER}

\section{Sure-Safe-Easy to Operate \\ FEATURES OF THE UP-TO-DATE HOVER}

Canopy-The Canopy is made from highest quality Galvanized Steel. Supporting legs are inside so as to give a more free access, also equipped with a raising and lowering bail which can be regulated with a rope or chain from ceiling.

Regulating Disc-Will at all times give a positive circulation of air underneath the hover which is very essential. The damper can be regulated to control the volume of air, and can be removed entirely leaving a 5-inch opening allowing a full view of flame and heater.

Base-Is steel stamped with the entire heater assembled and bolted to base which makes it more rigid and always level.

Draft Protector-This is very essential, as many chicks are lost from chilling when fire is blown out. It also keeps the chicks from coming in contact with any of the adjustments that control the burner, so the flame is always steady and even burning.

Air Duct--This feature is a good one. The air is drawn through the perforated plate underneath the Fuel Bottle passing through this long duct it is superheated before entering the burner, which not only gives a more even heat but a greater volume of heat from the same amount of fuel.

Oil Control Governor-This is the most improved feature of all, the governor prevents the flooding of the burner at all times. The fuel supply is always under perfect control, causing a smooth even burning flame, so the heat is always uniform regardless of weather conditions.

Valveless and Positive Oil Level-Once the burner is adjusted, the climatic conditions have no effect on the burner or flame.

Our improved heater is completely assembled on stamped steel base which will not warp, and all working parts are kept in perfect alignment.

We furnish the Up-To-Date asbestos lighting ring which is especially made for extreme heaters, and which are interwoven with many strands of small wire. These wicks do not deteriorate by their long use, for when they become carbonized it is only necessary to remove them from the burner, and place over a gas blaze or put into a coal fire and the carbon is burned off. You then have a new wick again. This can be done many times.

32 inch Canopy, 300 chicks, each $\$ 1350$

42 inch Canopy, 500 chicks, each. 1550 52 inch Canopy, 1000 chicks, each.

\section{AVICOL}

Most people lose half of every hatch and seem to expect it. Chicken cholera or white diarrhoea is the trouble.

Avicol is easily given in the water for either the prevention or treatment. Thousands of poultry raisers who have used Avicol are unanimous in their praise of it.

Price, 50c; large size, $\$ 1.00$, holds $2 \frac{1}{2}$ times the $50 \mathrm{c}$ size. 


\section{OLD TRUSTY INGUBATORS}

We keep these Incubators and Brooders in stock at all times, and any-order will have prompt attention. We have the several sizes that are manufactured. These Incubators for several seasons have outclassed anything in the Incubator line. So far as the cost is concerned, one batch will pay for the machine - the rest of the season is clear profit. Also the poultry business goes right along with any other business you are interested in and its profits are just that much ahead.

PRICES:

60 (70) egg, metal covered.

100 (120) egg, metal covered

1785

200 (240) egg, metal covered. 2725

We are distributors for Old Trusty Incubators and Brooders. We make same prices and same terms as factory and can make quick delivery. Send bank draft or money order.

\section{QUEEN INGUBATORS}

\section{STANDARD MACHINES}

The "Queen" Standard Incubator has been popularly known for the past twenty-three years, is an Incubator built upon principle and sound common sense.

Every detail of this machine has and is so carefully looked after that there is positively no chance for error in the materials used or in the construction details. Write for complete catalog.

No. 1- 85 egg

No. $2-135$ egg

No. 3-180 egg.

4400

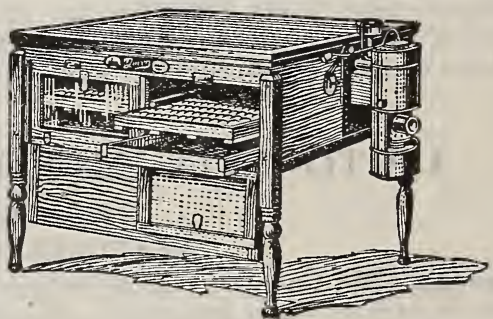

No. $4-275$ egg

$\$ 5775$

No. 5-400 egg.

6800

No. $21-130$ Egg Style K.................... 27.50

No. 22-220 Egg Style K.

36.75

\section{COAL BURNING HOVERS}

No. $1-500$ chick size.

$\$ 2150$

No. 2-1000 chick size

2550

\section{You will be entirely satisfied.}

\section{LITTLE BABY GRAND INGUBATORS}

\section{Egg Capacity, All Metal}

For the back yard poultry raiser wanting to make the most money out of a few chickens, this small incubator renders ideal service and gives satisfaction.

Unique and superior in construction. Beautiful in appearance; excellent in hatching qualities. The most reliable and easiest to operate small incubator ever offered. It has a glass window in top so thermometer can be seen without opening, and the chicks can be seen hatching without opening machine. It has positive heat and moisture regulation, and is equipped with a moisture receptacle for applying additional moisture when needed. Has double top, well insulated and packed; double side walls, with a free circulation of hot air between the walls all the time, making an equal distribution of heat through the machine at all times. The ventilation is perfect, supplying warm, fresh air to all parts of egg chamber at all times. Shipped by express or parcel post. Weight in carton, 20 pounds. Price each, $\$ \mathbf{7 . 5 0}$.

\section{The Oakes Economy Brooder Hover}

\section{All Steel, Light, Strong, and Durable.}

It furnishes plenty of heat with a small flame and is guaranteed to give satisfaction in every respect. The Economy Hover is complete in itself, and can be used anywhere, as it stands on a level floor-no platform, false floor, or other preparation necessary.

\section{PRICE}

No. 1 Hover (18-inch drum) without cage, $\$ 6.50$

Shipping weight, about 14 lbs.

No. 1 Hover, with wire cage, $\$ 9.00$

Shipping weight, about 25 pounds.
No. 2 Hover (22-inch drum) without cage, $\$ 10.00$ Shipping weight about 32 pounds.

No. 2 Hover, with wire cage, $\$ 13.00$ Shipping weight, about 43 pounds.

Prices do not include postage, express or freight charges. 


\section{Poultry Supplies--Continued}

\section{VACGINATE NOW}

For the Prevention and Treatment of Roup, Chicken Pox, Diphtheria, Canker, Colds, Catarrh, Cholera, etc.

Vaccination is simple and easy. An adult with one child as a helper can vaccinate 150 to 200 fowls an hour.

Vaccination is the one safe, inexpensive and scientific method of controlling these diseases. It reduces losses to a minimum and saves a large percentage of birds already infected.

\section{THE ORIGINAL}

\section{A. S. L. AVIAN MIXED BACTERIN}

is produced only by the American Scientific Labratories, Inc., under Veterinary License No. 165, issued by the U. S. Department of Agriculture.

60 doses, $\$ 2.00 ; 250$ doses, $\$ 5.00 ; 500$ doses, $\$ 7.50$; Syringe and Needles, $\$ 1.50$, postpaid, with full instructions.

Properly stored, A. S. L. Bacterin will retain its potency until the date shown on package-two years from date of manufacture.

FREE-New customers ordering both syringe and bacterin (any size) will be given FREE a $\$ 1.00$ package of GALLI-CURA TABLETS, the real White Diarrhea and other bowel disease preventive. Start the season right. It will pay you to vaccinate every bird you own.

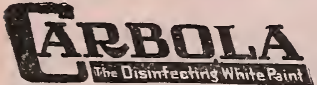
$\triangle$ WHITE paint and powA erful disinfectant in powder form. Quickly mixed with water-no waiting or straining. Applied with brush or sprayer to all surfaces.

Does not flake or peel off. One pound covers 100 square feet. Agricultural colleges and experiment stations highly recommend it for cleanliness and prevention of disease in -

Poultry Houses: To paint and disiniect side walls, ceilings, roosts and brooders. Helps keep the biros free from lice and mites and the buildings clean, light and sanitary. The dry powder is an excellent louse powder.

Barns and Stables: To paint and disinfect side walls, ceilings, stalls, etc., as an aid to cleanliness and prevention of tuberculosis, foot and mouth disease and other contagious diseases.

House and Garden: Carbola applied to walls and ceilings of cellars will kill bad odors, mustiness, prevent. cobwebs, disease germs, drive out spiders, ants and other insects. Dust Carbola on rose bushes, peas, cabbage, tomato plants, etc., to help rid of insects and worms. Spray it on trees and tree trunks.

Satisfaction or money back. 5 lb. pkg. $75 c$; $10 \mathrm{lbs}$. $\$ 1.25 ; 50 \mathrm{lbs}$. $\$ 5.00 ; 200 \mathrm{lbs}$. $\$ 18.00$

\section{CARBOLINEUM}

\section{Used for 3 Distinct Purposes}

1. Preserves wood everywhere against rot and decay and adds a least $100 \%$ to the life of fence posts, poles, sills, floors, bridge timbers, porches, wood imbedded in concrete, etc. On account of its nice brown color it is also a suitable wood preserving stain for shingle roofs, bungalows, cottages, farm buildings, barns, silos, ice houses, boat houses, garages, poultry houses and hog pens.
2. Kills Chicken Mites in poultry houses. Apply once a year. GUARANTEE-We guarantee that one thorough application of Avenarius Carbolineum either by brush or sprayer to the interior walls, dropping boards, roosts, etc., to such buildings, after a previous cleaning and no matter whether they are of wood, tar paper, or plaster, will exterminate mites in the same FOR A WHOLE YEAR.

3. Keeps flies from cattle, horses and hogs. You can make the best fly spray by using one part of Avenarius Carbolineum to three parts of machine oil. This spray used as per our directions. It is an excellent disinfectant in Hog Pens and is also used for general stable disinfection.

1 Gal. Cans, \$1.75; 10 Gallons, \$15.00.

\section{CAPONIZING SETS}

Caponizing Sets-Poultrymen can double their profits by caponizing. The operation is very simple, and the instructions are so full and explicit that any man, woman or child, after careful reading, will be able to perform the operation. It is highly successful from every point of view. The object in caponizing is to greatly increase the weight of the fowls, causing them in many cases to grow as large as turkeys, and weigh from 10 to 15 pounds, and the meat is of fine flavor, sweet, juicy, and tender. Ask for prices. 


\section{The "Harris Ready-to-Use"locked Plant Bands and Paper Pots}

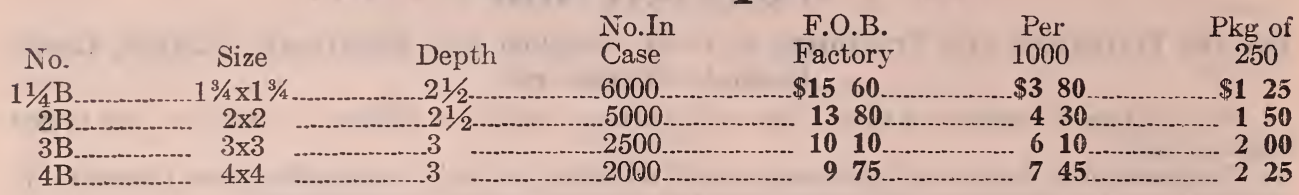

BANDS WITH FOLDING BOTTOMS OR POTS

Can be used as an extra deep band by leaving bottom unfolded. By pushing:the flaps in you have a square pot with bottom.

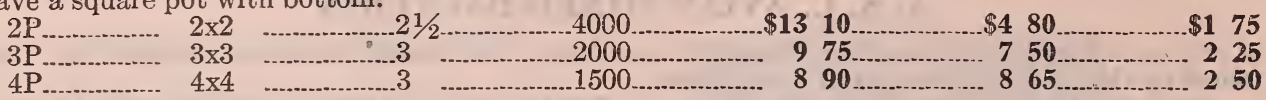

All bands packed 250 to a carton, in cases weighing about 47 pounds. Remember! Square bands and pots have nearly twice the cubic capacity of round pots of same diameter. Order next size smaller band than the round pot you generally use. Less than case lots at the 1,000 rate. 500 or less at the prepaid package rate. Terms: Cash with order. Unless definite shipping instructions are given we will use our best judgement.

\section{Our Frost-Proof Cabbage Plants}

To get the advantage of these frost-proof cabbage plants they must be planted a month or six weeks earlier than you would plant home-grown plants. We fill orders from December 1 to May 1.

The plants when received will be somewhat wilted and have a hard stunted appearance, which will be disappointing to persons who have never used these plants before. Regardless of appearance, they will produce the crop results.

\section{Varieties: Early Jersey Wakefield, Charleston Large Type Wakefield, Succession and Early Flat Dutch}

Prices by parcel post, postage paid: In lots of $100,200,300$, or 400 plants at per 100 plants $50 \mathrm{c}$; 500 plants for $\$ 1.60 ; 1000$ or more at $\$ 3.00$ per 1000 plants.

Orders are filled by the 100 , not 250 or 350 . These prices are for even quantities of one variety to package; if you ordered 200 of one variety and 300 of another variety you would pay at the 100 rate.

\section{Order Early to Get Plants Delivered in Time}

When we receive your order for these plants, we have to forward it to our growing station, which takes several days. Plants are shipped direct to you from growing station. Plants cannot be pulled or shipped when beds are wet. We sometimes have a week or ten days of continued wet weather which prevents shipment. If you do not receive your plants as soon as you expect them, you will know that weather prevents shipment. Send your order two to three weeks before you expeet to set the plants and you will get them on time.

\section{Bermuda Onion Plants}

Yellow Bermuda Plants at 35 c per $100 ; \$ 2.00$ per 1000 , postpaid.

Crystal White Wax Plants, ask for prices.

They may be set in the open field as early as you plant Onion Sets. Ask for prices on large quantities. 


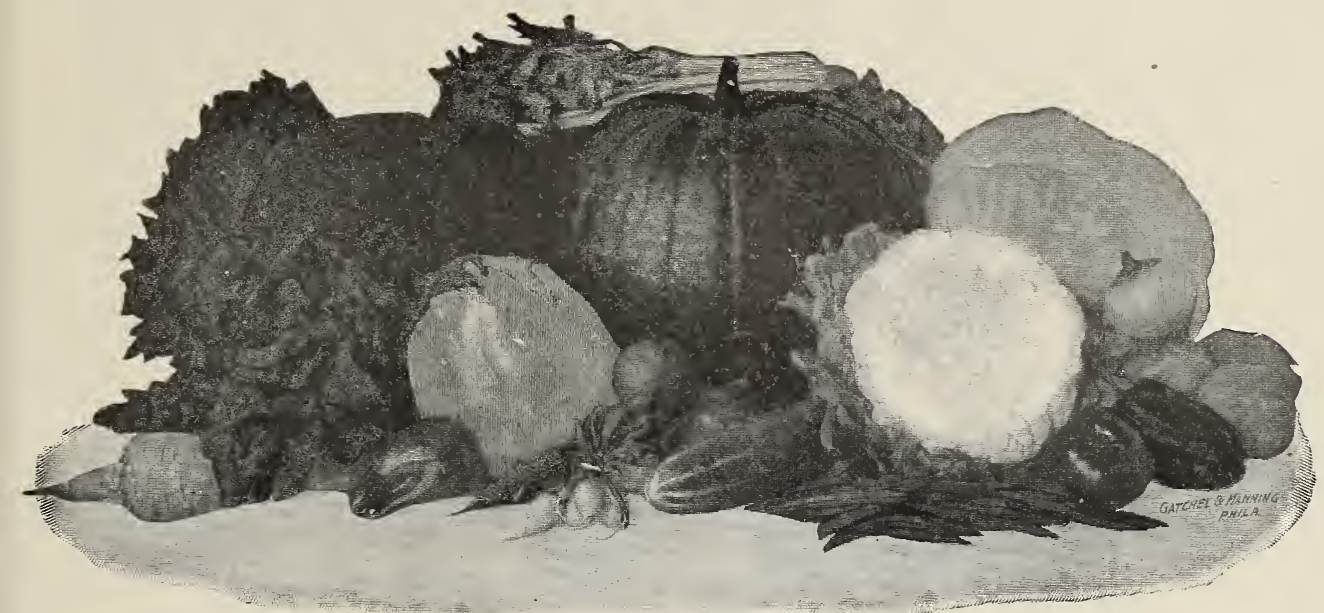

\section{Home Garden Collection 28 Varieties Best Garden Seeds for 90c Postpaid}

\section{A complete house garden assortment.}

To encourage more home garden planting, we are offering a remarkably, complete collection of the Best Vegetable Seeds. One packet of the following: Early Blcod Turnip Beet, Early Jersey Wakefield Cabbage, Burpee's Stringless Greenpod Beans, Kentucky Wonder Beans, Alaska Peas, Telephone Peas, Golden Bantam Sweet Corn, Henderson Bush Lima Beans, Chantenay Carrot, Davis Perfect Cucumber, Early Curled Simpson Lettuce, Hanson Head Lettuce, Rocky Ford Cantaloupe, Southern Giant Curled Mustard, White Velvet Okra, Red Wethersfield Onion, Moss Curled Parsley, Hollow Crown Parsnip, Chinese Giant Pepper, Long Red Cayenne Pepper, Early Scarlet Globe Radish, Icicle Radish, Bloomsdale Spinach, Early P.T. Strap Leaf Turnip, Seven Top Turnip, Earliana Tomato, Ponderosa Tomato, Early White Bush Squash.

NOTICE-This assortment cannot be changed as they have been put up complete. At our Regular Catalogue Prices the above collection would cost $\$ 1.75$. It is a Bargain.

THE ENTIRE 28 PACKETS SENT POSTPAID FOR 90c.

\section{SOLVE THE HIGH COST OF LIVING}

In Your Backyard This Year.

You can do it with very little effort by planting all vacant space in good vegetables, planting good seeds and cultivating your garden. You can have enough vegetables for table use in season and to can for use in the winter.

FOR TWENTY-FIVE CENTS we will send postpaid any six of our regular five-cent packets or any three of our regular ten-cent packets of Perfection Brand Garden and Flower Seeds. Purchasers' selection.

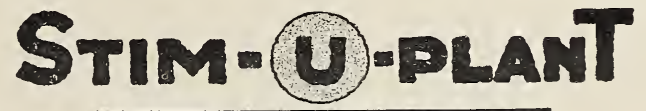

\section{PLANT STIMULANT TABLET}

Trade Mark Registered U. S. Patent Office

Use it and you will have the largest crops of fruit and vegetables and an abundance of the largest and sweetest-scented flowers of intense and vivid colors.

Here is the secret. Science has produced a tablet that is rich in plant food containing 11 percent Nitrogen. 12 percent Phosphoric Acid and 15 percent Potash, and it is odorless and clean. Compare this analysis with that of any other fertilizer.

It is not applied broadcast but is put at the feeder roots of the individual plants, so there is no waste and you feed the plants that need it. It produces no weeds like ordirary stable manure so it economizes in labor.

These tableis are the last word in modern garden efficiency-a proven success with rose growers, nurserymen, landscape gardeners strawberry growers and market gardeners

Complete directions with every package. Prices, postpaid: trial size (10 tahlets), 15e; 30 tablets 25 c; 100 tablets 75 c; $1000 \$ 3.50$. 


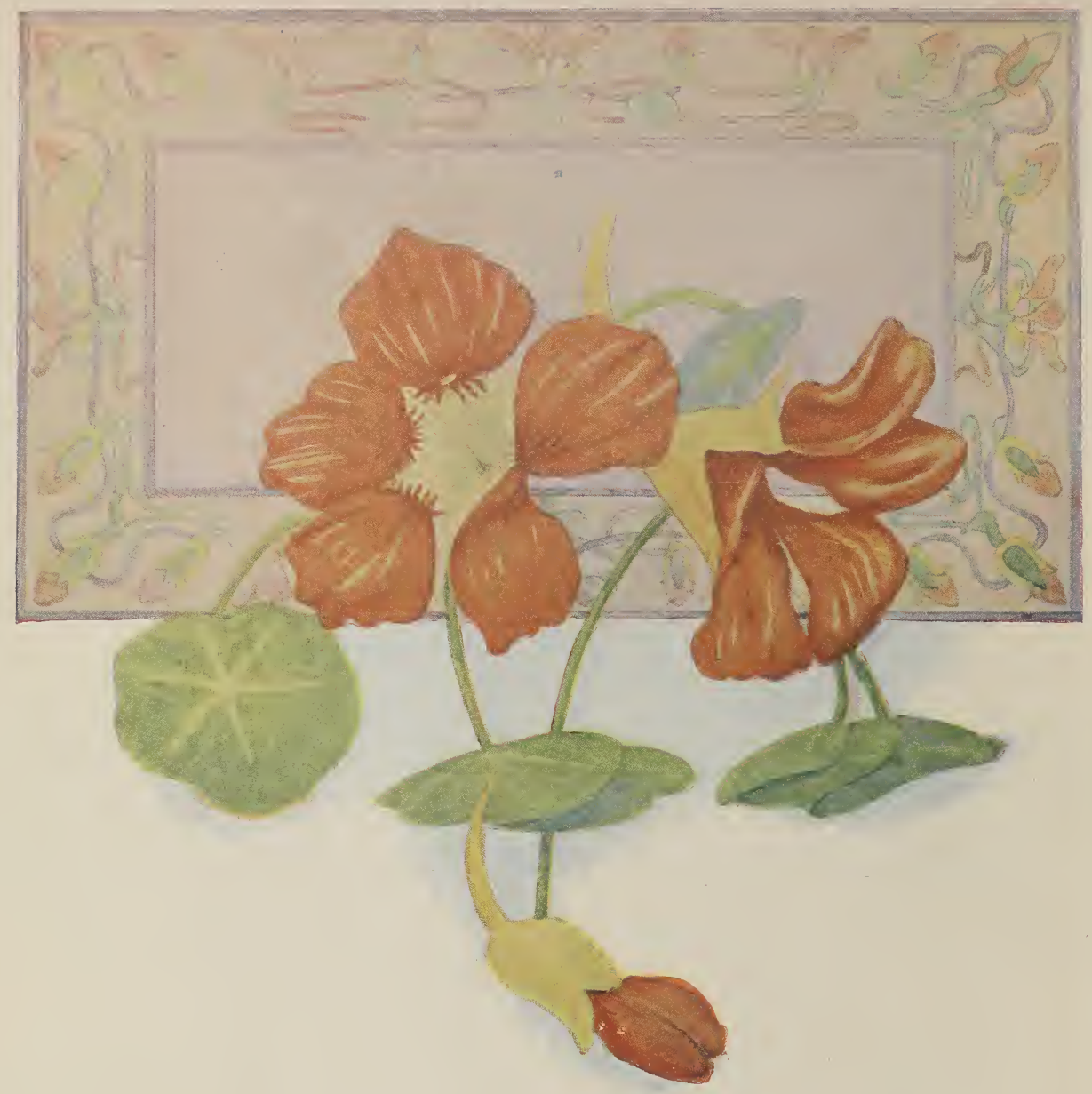

\section{Perfection Brand Flower Seed Collection 35c Postpaid}

We have selected only those sorts that are of easy culture and can be raised by any gardener whether in the city or in the country. They come into bloom, a few weeks after sowing and continue blooming until killed by a heavy frost. With a few exceptions they are the only ones that will give home gardeners a profusion of bloom during the mid-summer. 10 packets for $35 \mathrm{c}$.

1 pkt. Alyssum Iittle Gem.

1 pkt. Bachelor's Button Mixed.

1 pkt. Marigold; African Mixed.

1 pkt. Ornamental Castor Bean.

1 pkt. Calendula Mixed.
1 pkt. Calliopsis: Mixed.

1 pkt. Cosmos: Giant.

1 pkt. Zinnia; Giant Mixed.

1 pkt. Phlox Drummondi Mixed.

1 pkt. Petunia Mixed.

NASTURTIUMS-Probably the most widely grown of the universally popular fowers is the Nasturtium. If planted in a well drained and sunny position they will give within a few weeks a profusion of gorgeous blossoms lasting until frost. We have selected the strains best adapted to this section. For brilliancy range of color duration of bloom and general excellence they are unexcelled.

PERFECTION BRAND Mixed Tall Nasturtiums-Pkt.: 5c; oz.: 15c; 2 oz. 25c.

PERFECTION BRAND Dwarf Mixed Nasturtiums-Pkt.s 5c; oz. 15c; 2 oz. 25c.

THE BINDING-STEVENS SEED COMPANY, Tulsa, Oklahoma 